

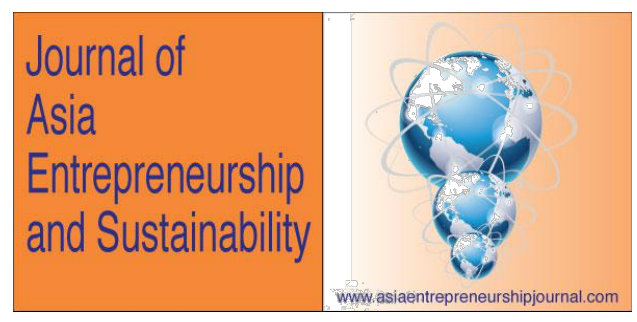

\section{Table of Content \\ Volume XV, Issue 1, June 2019}

Assessing Employees' Perception Related to

Entrepreneurial Climate in their Organization \&

its Impact on their Perception Related to Organization's

Potential Success

Prema Basargekar, Radha Iyer, Asha Bhatia

Page 3

Seeking for a relevant and contextual approach to economic development, an entrepreneurship model for Africa

L.E. Jowah

Page $\quad 67$

The role of the international community in preventing conflicts and establishing peace in North Macedonia Xhyla Çeliku

No is No, Maybe is No, Yes is Maybe:

Issues of authenticity and accuracy from interviews with Vietnamese and Mongolian entrepreneurs

Mike Turner, Richard Pech

The Effect of Religiosity, Spirituality and Family Power Influence on Family Business Sustainable Values

Zazli Lily Wisker, Vikinta Rosinaite, Balakrishnan Muniapan 


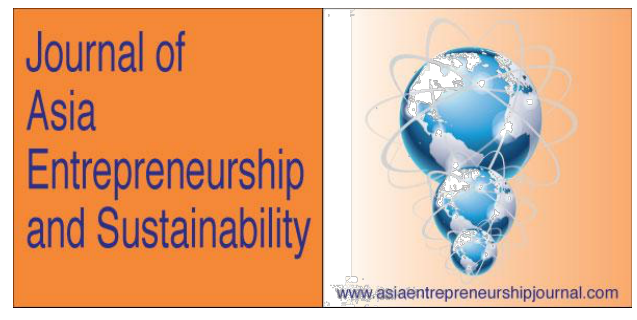

\title{
Assessing Employees' Perception Related to Entrepreneurial Climate in their Organization \& its Impact on their Perception Related to Organization's Potential Success
}

\author{
Prema Basargekar \\ Radha Iyer \\ Asha Bhatia
}

K. J. Somaiya Institute of Management Studies and Research, Mumbai, India

prema@somaiya.edu, radhaiyer@somaiya.edu, ashabahtia@somaiya.edu

\begin{abstract}
:
Corporate entrepreneurship plays an important role in stimulating innovations and giving a competitive edge to the organization in the long run. Positive and vibrant entrepreneurial climate within the organization is one of the building blocks of corporate entrepreneurship. . This study tries to assess the perception of entrepreneurial climate amongst the employees of Indian organizations. It covers perception of the employees on 13 different parameters of entrepreneurial climate

Page 3

(C) 2019 Journal of Asia Entrepreneurship and Sustainability Vol XV, Iss 1, June 2019

RossiSmith Academic Publications, Oxford/London UK, www.publicationsales.com
\end{abstract}




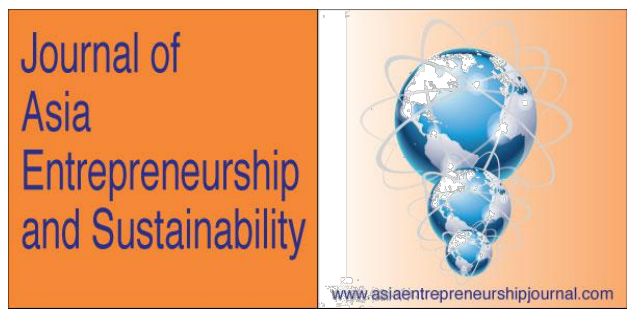

and attempts to find out the employees' related factors and organization related factors affecting entrepreneurial climate. The paper also tries to assess the impact of perception of entrepreneurial climate of employees on their perception related to potential success of their organization.

The study uses primary data collection from 633 employees from the corporate sector. It uses descriptive and inferential analysis such as One Sample T-test, ANOVA and Regression analysis to arrive at the conclusions. The study concludes that employees' perception related to entrepreneurial climate in their organizations is affected by their age-group and their seniority in the management cadre. Employees belonging to manufacturing and engineering sectors have more positive outlook towards entrepreneurial climate than other sectors. The study also found that there is a positive and significant relationship between employees' perception related to the entrepreneurial climate within their organizations and their perception related to potential success of their organizations.

\section{Introduction:}




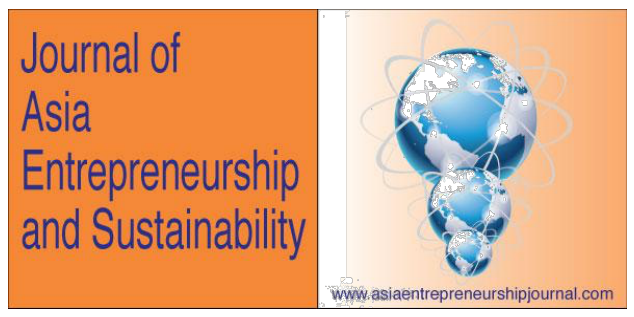

Corporate entrepreneurship plays an important part in stimulating innovations and giving a competitive edge to the organization in the long run. Internal environmental factors within the organization decide the entrepreneurial climate which in turns builds corporate entrepreneurship. The role of management in developing entrepreneurial climate is very crucial. This study tries to assess the perception of entrepreneurial climate amongst the employees of Indian organizations. It covers perception of the employees on 13 different parameters of entrepreneurial climate. It attempts to find out whether the perception differs significantly as per the socio-demographic attributes of the employees such as gender, age-group and level of management cadre and attributes of the organization such as size and sector. The paper also tries to assess the impact of perception of entrepreneurial climate of employees on their perception related to potential success of their organization.

\section{Objectives:}

- To assess the level of entrepreneurial climate of the Indian organizations

- To assess the impact of various employees related attributes such as gender, age-group and level of management cadre on the entrepreneurial climate.

- To assess the impact of various organization related attributes such as size of the organization and the sector in which the organization is functioning on the entrepreneurial climate. 


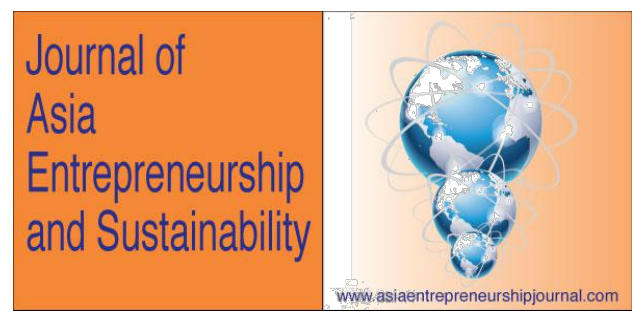

- To see the impact of employees' perception related to entrepreneurial climate on their perception related to potential success of the organizations.

\section{Literature review:}

The review of literature covers various dimensions of entrepreneurial climate in the organizations. It covers the meaning and relevance of building entrepreneurial climate and corporate entrepreneurship, internal and external factors impacting entrepreneurial climate within the organizations, linkages between entrepreneurial climate and organizational innovations, etc.

Corporate entrepreneurship is relatively a nascent concept developed during 1980s. It encompasses several characteristics such as process of diversification through internal development, transforming individual initiatives into collective action, giving birth to new business within the existing organization, new product/ market development through innovations, employees initiatives, etc. (Sharma and Chrisman: 1999). Zahra (1993) defined corporate entrepreneurship as a process of organizational renewal that has two distinct but related dimensions such as innovation and venturing and strategic renewal. Kuratko, Hornsby \& Hayton, J. (2015) conclude that corporate entrepreneurship provides a sustainable competitive advantage to the organization by helping it in strategic renewal, improve 


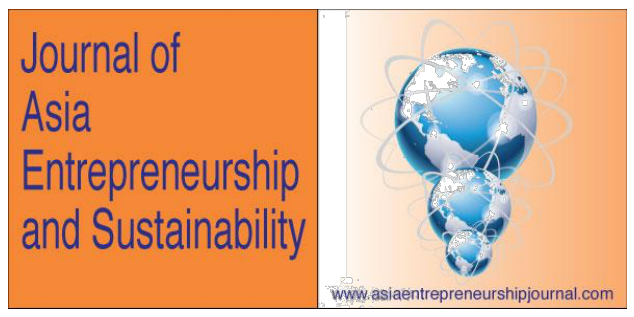

profitability, develop future income streams, gain international success and use the resources more effectively. It is impacted by five factors viz autonomy, innovativeness, risk taking, pro-activeness and competitive aggression. (Lumpkin and Dess: 1996).

Entrepreneurial climate is nothing but creation of an environment in which all the stakeholders, especially the employees of the organization are encouraged to pursue attractive business opportunities. Vibrant entrepreneurial ecosystem requires clear understanding of interdependency of all the stakeholders such as entrepreneurs, employees, investors and institutions. Optimistic and innovation driven employees can contribute more to make the business successful (Jenne, Rigby and Allum: 2016). The management needs to cultivate the higher level of interaction and trust with the employees to build such an environment (Ramachandran et al: 2006).

The previous literature elaborates on various dimensions of entrepreneurial climate and its impact on organization's success. Organizational policies and strategies play an important role in building and entrepreneurial climate. Entrepreneurial environment is built by barrier free organizations (Dess et al: 1999). They suggested that structural features combined with efficiency and processes lead to 


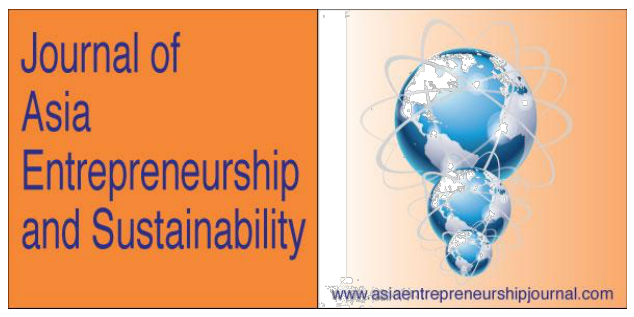

excellent results. Wiklund and Shepherd (2011) reinforce the tolerance for mistakes in the process of generating initiatives of high and quick performance. Kuratko, Montagno, and Hornsby (1990) empirically identified "reward and resource availability" as a principal determinant of entrepreneurial behavior by managers. Entrepreneurial strategy forms a core construct with respect to firmlevel entrepreneurship. Cooper et al. (2000, p. 120) opined that "entrepreneurial strategy is a potential source of firms' competitive advantage, a way in which established firms can develop capabilities that are central to their continuing success." . Montoro-Sánchez \& Domingo (2011) showed with the help of examples of number of companies that human resource policies implemented at the organizational level help to build openness in the communication, to create personal relationships, to reward employees for innovative behavior and to easily transfer knowledge within employees leads to entrepreneurial success. Competencies such as knowledge, multidisciplinary approach, tenacity and passion help in sponsoring entrepreneurship in organizations (Hayton \& Kelley 2006).

Along with the organizational policies and strategies, organizational leadership also plays an important role in building entrepreneurial climate. Leader's and organizational support have positive, and also strong impact on the entrepreneurial behavior.(Turunç \& Altuntepe 2015). Kang (2013) proved that transformational 


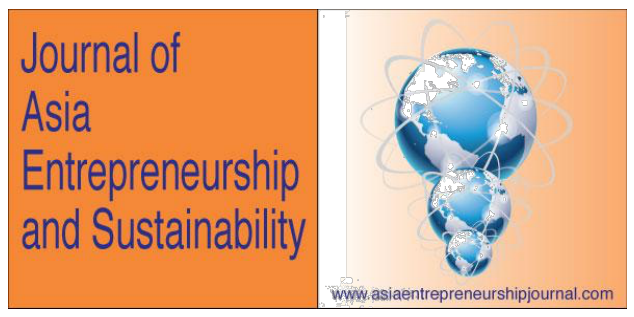

leadership in the organizations leads to innovative behavior of the managers. Zbierowski (2016) showed that positive leadership depicting appreciation, collaboration, honesty and trust can develop psychological capital. Psychological capital can develop self-awareness, self-regulation which in turn develops selfefficacy which is very important for building entrepreneurial attitudes in the employees.

Margarietha (2012) found that entrepreneurial intensity of the organization is significantly influenced by the perception of the employees in relation to management support, autonomy and reward management system in the organization. These three act as antecedents of the entrepreneurial environment which guide managerial decisions impacting corporate entrepreneurship. Hornsby et al (2009) studied the perception of the managers related to the antecedents of the corporate entrepreneurship. They found that it differs across the management levels. Senior and middle level managers have more positive perception of the antecedents such as management support, autonomy and reward system as compared to first level managers. Rutherford \& Holt (2007) also concluded that two primary antecedents of corporate entrepreneurship i.e. leadership support and open communication are effective in building positive perception of the mangers 


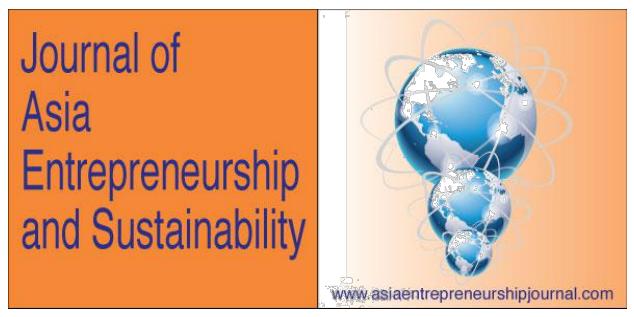

related to entrepreneurial culture which in turn leads to positive entrepreneurial behavior and better job satisfaction.

Structure and the size of the organization may also influence the entrepreneurial climate. Flat structures put the top of organizations closer to operational levels, accelerating decision-making and facilitating the development of innovative proposals and ideas (Marvel et al., 2007). The leaner the structures, the less they depend on formal communication channels, consequently favoring the flow of information that feeds the ability to identify opportunities and develop innovative ideas (Farrell, 1993). Moreover, organizations with less-centralized structures tend to generate more ideas because managers have more autonomy and control on resources, making it possible for more usable creative ideas. (Mintzberg, 2008; Pierce \& Delbecq, 1977, Sebora and Theerapatvong:2009; Morris et al:2008). Along with these, Lumpkin and Dess (1996) also emphasized on cross functional work groups and their accountability. The existing research agrees that cross functional teams act as a catalyst for creating entrepreneurial culture within the organization as it brings diversity and dynamism required to initiate the entrepreneurial process. Two important conditions to create and sustain cross functional teams are open communication through explicit and implicit manner and support from the top management (Ferdousi:2012).

Page 10

(C) 2019 Journal of Asia Entrepreneurship and Sustainability Vol XV, Iss 1, June 2019 RossiSmith Academic Publications, Oxford/London UK, www.publicationsales.com 


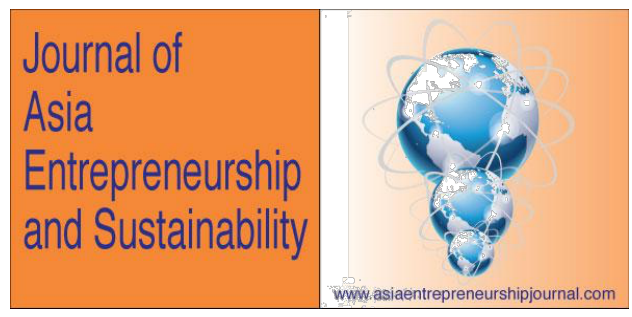

The size of the organization provides advantages as well as disadvantages to promote innovations. Though more flexibility, closer relationship with the customers, lower level of bureaucracy may encourage innovation in SMEs, they also face innumerable challenges in promoting innovations (Projogo et al: 2013). Along with commonly understandable challenges such as insufficient resources, absence of expertise required for research, etc. some of the challenges are unique. One of them is even though enough resources can be procured, allocating them appropriately in various teams is difficult.(Petkovska: 2015). Limited size of the local market where the product/ service is offered also acts as a barrier for further innovations (Kotey: 2014).

Lastly, the socio-demographic attributes of the employees may also have impact on the organizational entrepreneurial climate. Holt, Rutherford, \& Clohessy, (2007) stated that corporate entrepreneurship is influenced by individual characteristics of the employees in the organizational context. Supportive management, work discretion and proper reward and reinforcement system encourage employyes to become more entrepreneurial. Preisendoerfer, Bitz and Bezuidenhoutmention that socio-demographic attributes of the person such as gender, age, etc affect the entrepreneurial behavior and intensions. For instance females are more likely to be 


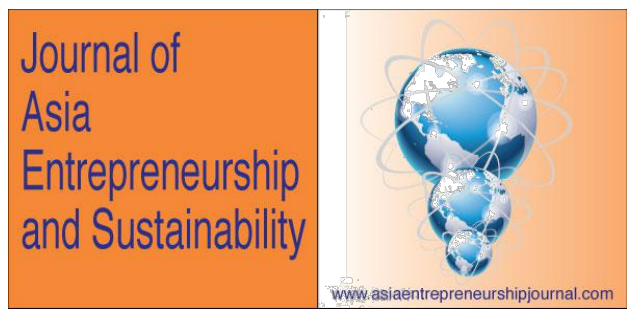

underrepresented in entrepreneurial ventures and middle aged persons are more likely to have a higher tendency towards entrepreneurship than younger and older age group. Sebora, T. C., \& Theerapatvong, T. (2010) found a positive relationship between entrepreneurial characteristics of upper level managers and the idea generation, risk taking ability and proactive decisions taken by the firms. Chen, Zhu, \& Wang (2005) empirically found that entrepreneurial abilities of the senior executives can be cultivated and they influence the corporate entrepreneurship. At the same time strategic entrepreneurial management leads to cultivate corporate entrepreneurship and further to higher growth rate through innovations. Assessment and monitoring of entrepreneurial climate within the organization is the need of an hour. Ireland, Kuratko, \& Morris (2006) have provided a tool "entrepreneurial health audit" through which the organization can diagnose or assess the level of entrepreneurial behavior within the organization by testing entrepreneurial climate. It uses five parameters such as management support, work discretion or autonomy, reinforcement, time availability and organizational boundaries.

The existing literature shows that very few studies have been made to assess the entrepreneurial climate of the organizations in developing countries like India.

\section{Methodology:}

Page 12

(C) 2019 Journal of Asia Entrepreneurship and Sustainability Vol XV, Iss 1, June 2019 RossiSmith Academic Publications, Oxford/London UK, www.publicationsales.com 


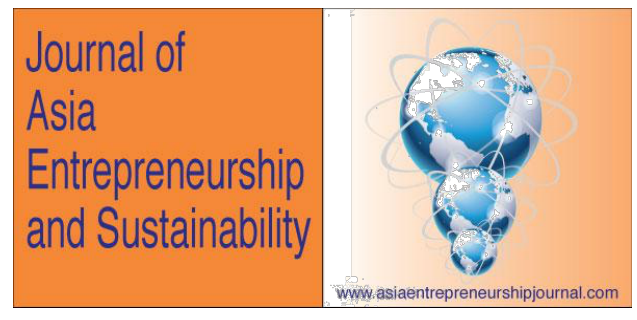

\begin{tabular}{|c|c|c|}
\hline Sr. No & Parameters & Brief Description \\
\hline 1 & $\begin{array}{l}\text { Entrepreneurial } \\
\text { leadership }\end{array}$ & $\begin{array}{l}\text { Leaders capable of setting } \\
\text { the organization's vision } \\
\text { and creating strategies, } \\
\text { space, systems, processes } \\
\text { and culture for employees } \\
\text { to pursue opportunities. }\end{array}$ \\
\hline 2 & $\begin{array}{l}\text { Management } \\
\text { support }\end{array}$ & $\begin{array}{l}\text { Provision of resources } \\
\text { and creating a structure to } \\
\text { encourage research and } \\
\text { innovations; recognize } \\
\text { and nurture talent and } \\
\text { efforts. }\end{array}$ \\
\hline 3 & $\begin{array}{l}\text { Sponsorship } \\
\text { (champion) }\end{array}$ & $\begin{array}{l}\text { Encourage, support, } \\
\text { mentor and protect } \\
\text { intrapreneurs, remove } \\
\text { obstacles. }\end{array}$ \\
\hline
\end{tabular}

Page 13

(C) 2019 Journal of Asia Entrepreneurship and Sustainability Vol XV, Iss 1, June 2019 RossiSmith Academic Publications, Oxford/London UK, www.publicationsales.com 


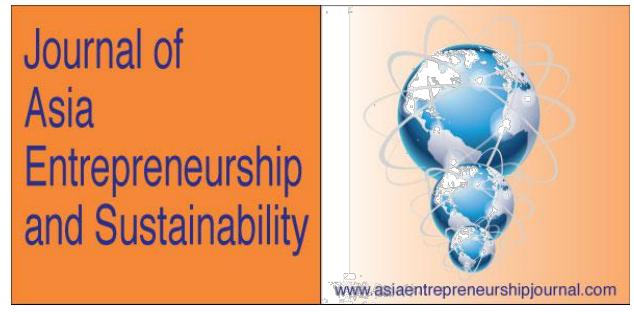

\begin{tabular}{|c|c|c|}
\hline 4 & $\begin{array}{l}\text { Tolerance for } \\
\text { risk, mistakes and } \\
\text { failure }\end{array}$ & $\begin{array}{l}\text { Allowing mistakes to be } \\
\text { made for fostering } \\
\text { entrepreneurial behavior. }\end{array}$ \\
\hline 5 & $\begin{array}{l}\text { Encouragement } \\
\text { to Innovations \& } \\
\text { New ideas }\end{array}$ & $\begin{array}{l}\text { Encourage various types } \\
\text { of innovations like } \\
\text { product, process, market, } \\
\text { etc. and quickly } \\
\text { implement new ideas. }\end{array}$ \\
\hline 6 & $\begin{array}{l}\text { Appropriate } \\
\text { awards and } \\
\text { reinforcement }\end{array}$ & $\begin{array}{l}\text { Establish the monetary } \\
\text { and non-monetary reward } \\
\text { system for encouraging } \\
\text { efforts and collaboration. }\end{array}$ \\
\hline 7 & $\begin{array}{l}\text { Vision \& } \\
\text { Strategic intent }\end{array}$ & $\begin{array}{l}\text { Establish a long-term } \\
\text { strategy to encourage } \\
\text { entrepreneurship and } \\
\text { align organizational } \\
\text { culture with it. }\end{array}$ \\
\hline 8 & $\begin{array}{l}\text { Discretionary } \\
\text { time \& work }\end{array}$ & $\begin{array}{l}\text { Provide autonomy and } \\
\text { supporting job-structure }\end{array}$ \\
\hline
\end{tabular}

Page 14

(C) 2019 Journal of Asia Entrepreneurship and Sustainability Vol XV, Iss 1, June 2019 RossiSmith Academic Publications, Oxford/London UK, www.publicationsales.com 


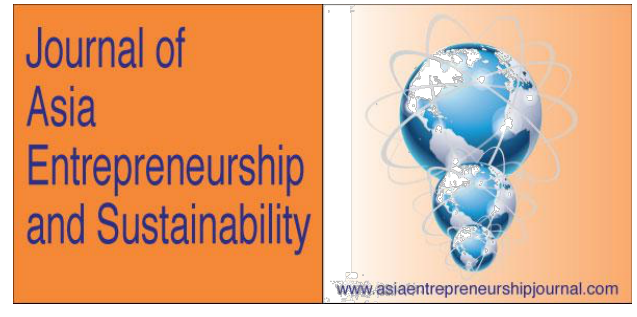

\begin{tabular}{|l|l|l|}
\hline \multirow{2}{*}{} & Empowered / & $\begin{array}{l}\text { for stimulating } \\
\text { intrapreneurship. }\end{array}$ \\
\hline 9 & $\begin{array}{l}\text { Multi- } \\
\text { disciplinary } \\
\text { teamwork }\end{array}$ & $\begin{array}{l}\text { Encourage collaborative } \\
\text { and multi-disciplinary } \\
\text { team-work. }\end{array}$ \\
\hline 10 & Resource & \\
\hline 11 & availability and & Provide money, people, \\
& accessibility & time, resources for \\
& Continuous and & Providitating innovations. \\
& Cross-functional & personal growth and give \\
& learning & cross-functional exposure \\
& to employees. \\
\hline 12 & Strong customer & Orient customer driven \\
& orientation & innovations and engage \\
& customers in all stages of \\
& Flat & Build decentralized less \\
& & hierarchical structure and \\
\hline 13 & &
\end{tabular}

Page 15

(C) 2019 Journal of Asia Entrepreneurship and Sustainability Vol XV, Iss 1, June 2019 RossiSmith Academic Publications, Oxford/London UK, www.publicationsales.com 


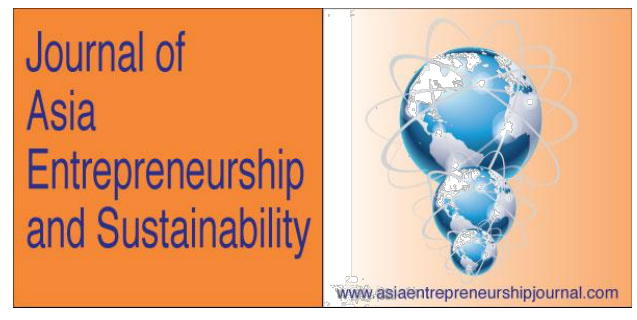

\begin{tabular}{|l|l|l|}
\hline & $\begin{array}{l}\text { structure \& open } \\
\text { communication }\end{array}$ & facilitate open \\
& communication \\
\hline
\end{tabular}

The study uses primary data collection from 633 employees from the corporate sector. The questionnaire to test corporate entrepreneurial climate was designed by Oasthuizen in 2006, then adapted by Jordaan in 2008 and is an accepted tool to measure entrepreneurial climate within the organization. Cronbach Alpha coefficient was found out to be 0.96 which shows the data is reliable and internally consistent. The study classifies the data into13 parameters/ constructs which has been taken by earlier studies (Govender: 2010, Motlhasedi: 2010, Melk:2010). The 5 point Likert scale is used to assess the perception of the surveyed employees. Hence any score less than 3 shows that the perception is low and any score higher than 3 shows the perception is high. 


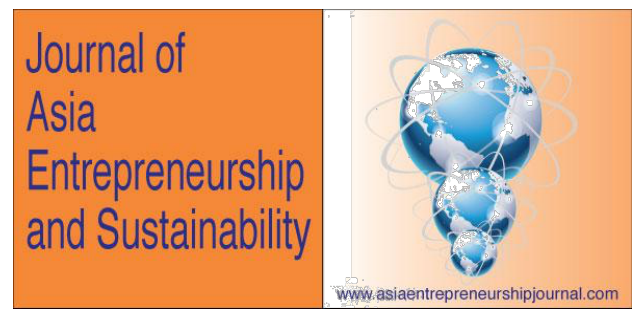

The brief description of 13 parameters to measure entrepreneurial climate is given below:

Note: Taken from - "An assessment of Corporate Entrepreneurship in Petrochemical Company" - D Govender, (2010), Mini-dissertation submitted in partial fulfillment of the requirements for the degree in Masters in Business Administration at the North-West University, Potchefstroom campus.

\section{Data analysis:}

Table 1 gives the descriptive analysis of the sample.

Table 1: Descriptive information of the sample:

\begin{tabular}{|c|c|c|c|c|}
\hline $\begin{array}{c}\text { Sr } \\
\text { No }\end{array}$ & Parameter & Categories & $\begin{array}{c}\text { Total } \\
\text { No }\end{array}$ & Percent \\
\hline 1 & Gender & 1. Male & 451 & 71.2 \\
\hline & & 2. Female & 173 & 27.3 \\
\hline & & $\begin{array}{l}3 . \text { Not } \\
\text { mentioned }\end{array}$ & 9 & 1.4 \\
& & 4. Total & 633 & 100 \\
\hline
\end{tabular}




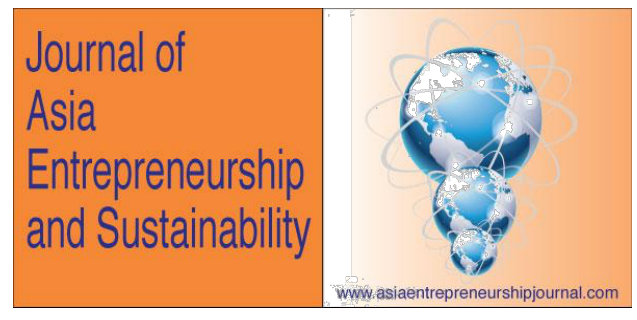

\begin{tabular}{|c|c|c|c|c|}
\hline 2 & $\begin{array}{l}\text { Management } \\
\text { level }\end{array}$ & $\begin{array}{l}\text { 1. Top } \\
\text { management }\end{array}$ & 18 & 2.8 \\
\hline & & 2. Senior level & 100 & 15.8 \\
\hline & & 3. Middle level & 294 & 46.4 \\
\hline & & 4. Other & 141 & 22.3 \\
\hline & & $\begin{array}{l}\text { 5. Not } \\
\text { mentioned }\end{array}$ & 80 & 14.7 \\
\hline & & 6. Total & 633 & 100 \\
\hline \multirow[t]{4}{*}{3} & $\begin{array}{l}\text { Organization's } \\
\text { size }\end{array}$ & $\begin{array}{l}\text { 1. } \text { Micro }(<5 \\
\text { employees })\end{array}$ & 3 & 0.5 \\
\hline & & $\begin{array}{l}\text { 2. Small (6 to } \\
50 \\
\text { employees) }\end{array}$ & 39 & 6.2 \\
\hline & & $\begin{array}{l}\text { 3. Medium (51 } \\
\text { to } 200 \\
\text { employees) }\end{array}$ & 60 & 9.5 \\
\hline & & $\begin{array}{l}\text { 4. Large (2001 } \\
+ \\
\text { employees) }\end{array}$ & 524 & 82.8 \\
\hline
\end{tabular}

Page 18

(C) 2019 Journal of Asia Entrepreneurship and Sustainability Vol XV, Iss 1, June 2019

RossiSmith Academic Publications, Oxford/London UK, www.publicationsales.com 


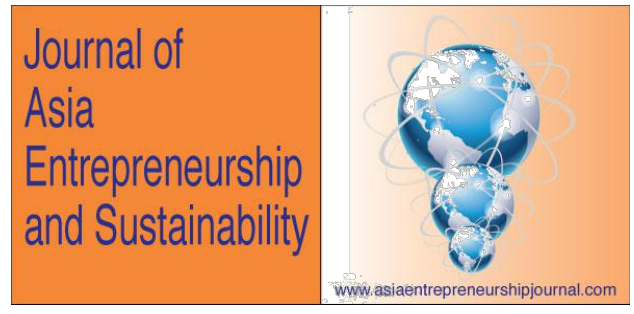

\begin{tabular}{|c|c|c|c|c|}
\hline & & $\begin{array}{l}\text { 5. Not } \\
\text { mentioned }\end{array}$ & 7 & 1.1 \\
\hline \multirow{2}{*}{4} & Average years & 5. Total years & Min & Max -36 \\
& in the & & - & \\
& organization & & 0.50 & \\
\hline
\end{tabular}

The descriptive analysis shows that more than 75 percent of the surveyed sample belongs to the age group of less than 49 years. More than 70 percent are male Most of the sample are either graduate or post graduate. More than 46 percent represents the middle level of management followed by 16 percent at senior level. Majority of the sample belong to large organization. Average years of experience with the organization are found out to be 5.6 years.

\section{Inferential analysis:}

Objective I: To assess the entrepreneurial climate of the Indian organizations.

$\mathrm{H}_{01}$ : Employees have neutral perception related to entrepreneurial climate in their organizations.

$\mathrm{H}_{11}$ : Employees do not have neutral perception related to entrepreneurial climate in their organizations. 


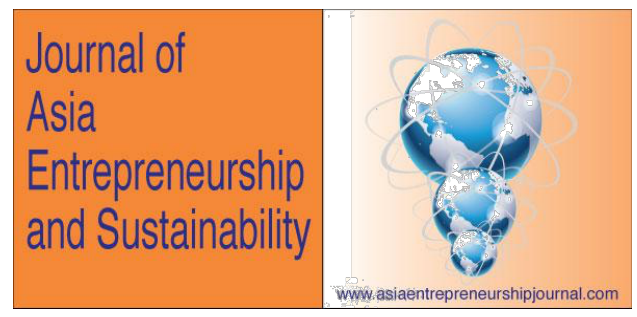

One Sample T-test is used to validate the hypotheses. Table 2 gives the details of the same.

Table 2: One-Sample Statistics of 13 parameters of entrepreneurial climate:

\begin{tabular}{|c|c|c|c|c|c|}
\hline $\begin{array}{l}\text { Sr. } \\
\text { no }\end{array}$ & Parameter & Number & Mean & Std. Dev. & $\begin{array}{l}\text { Std. } \\
\text { Error }\end{array}$ \\
\hline 1 & $\begin{array}{l}\text { Entrepreneurial } \\
\text { leadership }\end{array}$ & 602 & 3.56 & .72 & .02 \\
\hline 2 & $\begin{array}{l}\text { Management } \\
\text { support }\end{array}$ & 603 & 3.55 & .64 & .02 \\
\hline 3 & $\begin{array}{l}\text { Sponsorship } \\
\text { (champion) }\end{array}$ & 613 & 3.34 & .81 & .03 \\
\hline 4 & $\begin{array}{l}\text { Tolerance for } \\
\text { risk, mistakes } \\
\text { and failure }\end{array}$ & 582 & 3.46 & .63 & .02 \\
\hline 5 & $\begin{array}{l}\text { Encouragement } \\
\text { to Innovations } \\
\& \text { New ideas }\end{array}$ & 587 & 3.50 & .68 & .02 \\
\hline
\end{tabular}

Page 20

(C) 2019 Journal of Asia Entrepreneurship and Sustainability Vol XV, Iss 1, June 2019 RossiSmith Academic Publications, Oxford/London UK, www.publicationsales.com 


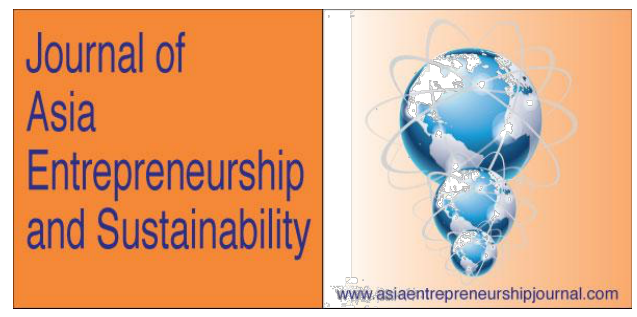

\begin{tabular}{|c|c|c|c|c|c|}
\hline 6 & $\begin{array}{l}\text { Appropriate } \\
\text { awards and } \\
\text { reinforcement }\end{array}$ & 594 & 3.51 & .75 & .03 \\
\hline 7 & $\begin{array}{l}\text { Vision \& } \\
\text { Strategic intent }\end{array}$ & 594 & 3.64 & .76 & .03 \\
\hline 8 & $\begin{array}{l}\text { Discretionary } \\
\text { time \& work }\end{array}$ & 602 & 3.55 & .71 & .02 \\
\hline 9 & $\begin{array}{l}\text { Empowered / } \\
\text { Multi- } \\
\text { disciplinary } \\
\text { teamwork }\end{array}$ & 615 & 3.47 & .79 & .03 \\
\hline 10 & $\begin{array}{l}\text { Resource } \\
\text { availability and } \\
\text { accessibility }\end{array}$ & 598 & 3.32 & .73 & .03 \\
\hline 11 & $\begin{array}{l}\text { Continuous and } \\
\text { Cross- } \\
\text { functional } \\
\text { learning }\end{array}$ & 582 & 3.53 & .69 & .02 \\
\hline
\end{tabular}

Page 21

(C) 2019 Journal of Asia Entrepreneurship and Sustainability Vol XV, Iss 1, June 2019 RossiSmith Academic Publications, Oxford/London UK, www.publicationsales.com 


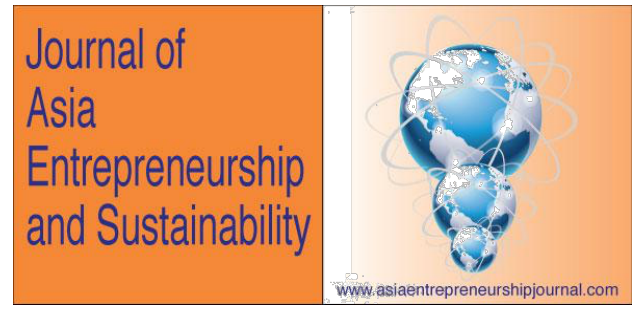

\begin{tabular}{|l|l|l|l|l|l|}
\hline 12 & $\begin{array}{l}\text { Strong } \\
\text { customer } \\
\text { orientation }\end{array}$ & 613 & 3.80 & .72 & .02 \\
\hline 13 & $\begin{array}{l}\text { Flat } \\
\text { organizational } \\
\text { structure \& } \\
\text { open } \\
\text { communication }\end{array}$ & 584 & 3.49 & .65 & .02 \\
& $\begin{array}{l}\text { Overall } \\
\text { Entrepreneurial } \\
\text { Climate }\end{array}$ & 395 & 3.55 & .59 & .02 \\
\hline
\end{tabular}

The T-statistics shows that $\mathrm{P}<0.05$ for all the 13 parameters. Hence it is proved that employees have a positive perception about entrepreneurial climate in their organizations. The overall mean value of entrepreneurial climate is 3.55 . The "Strong customer value" has highest mean value of 3.80. The "Resource availability and accessibility" has lowest mean value of 3.32 .

Page 22

(C) 2019 Journal of Asia Entrepreneurship and Sustainability Vol XV, Iss 1, June 2019 RossiSmith Academic Publications, Oxford/London UK, www.publicationsales.com 


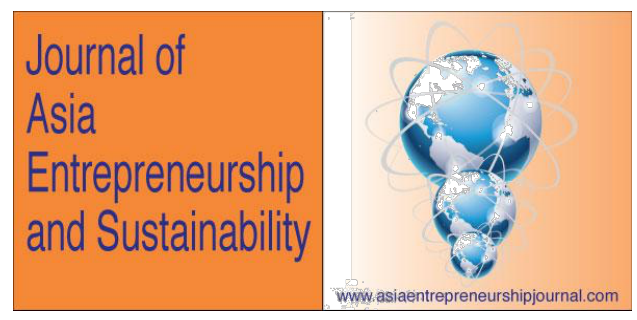

Objective II: To assess the impact of various employees related attributes such as gender, age-group and level of management cadre on the entrepreneurial climate.

\begin{tabular}{|l|l|l|l|l|l|l|}
\hline $\begin{array}{l}\text { Sr. } \\
\text { No }\end{array}$ & Parameter & Categories & Number & Mean & Std. Dev. & Std. Error \\
\hline 1 & $\begin{array}{l}\text { Entrepreneurial } \\
\text { leadership }\end{array}$ & Male & 433 & 3.58 & 0.71 & 0.03 \\
\hline & & Female & 161 & 3.55 & 0.77 & 0.06 \\
\hline & & Total & 594 & 3.57 & 0.73 & 0.03 \\
\hline 2 & $\begin{array}{l}\text { Management } \\
\text { support }\end{array}$ & Male & 427 & 3.53 & 0.64 & 0.03 \\
\hline & & Female & 167 & 3.60 & 0.67 & 0.05 \\
\hline 3 & $\begin{array}{l}\text { Sponsorship } \\
\text { (champion) }\end{array}$ & Male & 594 & 3.55 & 0.65 & 0.03 \\
\hline & & Female & 165 & 3.43 & 0.85 & 0.07 \\
\hline & & Total & 604 & 3.35 & 0.82 & 0.03 \\
\hline
\end{tabular}

Page 23

(C) 2019 Journal of Asia Entrepreneurship and Sustainability Vol XV, Iss 1, June 2019 RossiSmith Academic Publications, Oxford/London UK, www.publicationsales.com 


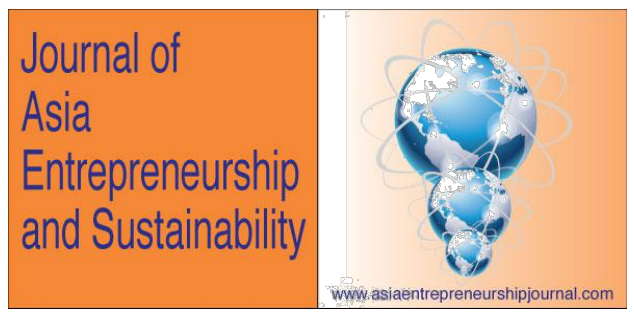

\begin{tabular}{|c|c|c|c|c|c|c|}
\hline 4 & $\begin{array}{l}\text { Tolerance for } \\
\text { risk \& failure }\end{array}$ & Male & 409 & 3.47 & 0.65 & 0.03 \\
\hline & & $\begin{array}{l}\text { Fem } \\
\text { ale }\end{array}$ & $\begin{array}{l}16 \\
5\end{array}$ & 3.44 & 0.60 & 0.05 \\
\hline & & Total & $\begin{array}{l}57 \\
4\end{array}$ & $\begin{array}{l}3 \\
\cdot \\
4 \\
6\end{array}$ & $\begin{array}{l}0.6 \\
3\end{array}$ & $\begin{array}{l}0.0 \\
3\end{array}$ \\
\hline & $\begin{array}{l}\text { Encoura } \\
\text { gement } \\
\text { to New } \\
\text { ideas }\end{array}$ & Male & $\begin{array}{l}41 \\
8\end{array}$ & $\begin{array}{l}3 \\
\cdot \\
4 \\
9\end{array}$ & $\begin{array}{l}0.6 \\
8\end{array}$ & $\begin{array}{l}0.0 \\
3\end{array}$ \\
\hline & & $\begin{array}{l}\text { Fem } \\
\text { ale }\end{array}$ & $\begin{array}{l}16 \\
0\end{array}$ & $\begin{array}{l}3 \\
. \\
5 \\
5\end{array}$ & $\begin{array}{l}0.7 \\
1\end{array}$ & $\begin{array}{l}0.0 \\
6\end{array}$ \\
\hline & & Total & $\begin{array}{l}57 \\
8\end{array}$ & $\begin{array}{l}3 \\
\cdot \\
5 \\
1\end{array}$ & $\begin{array}{l}0.6 \\
9\end{array}$ & $\begin{array}{l}0.0 \\
3\end{array}$ \\
\hline
\end{tabular}

Page 24

(C) 2019 Journal of Asia Entrepreneurship and Sustainability Vol XV, Iss 1, June 2019 RossiSmith Academic Publications, Oxford/London UK, www.publicationsales.com 


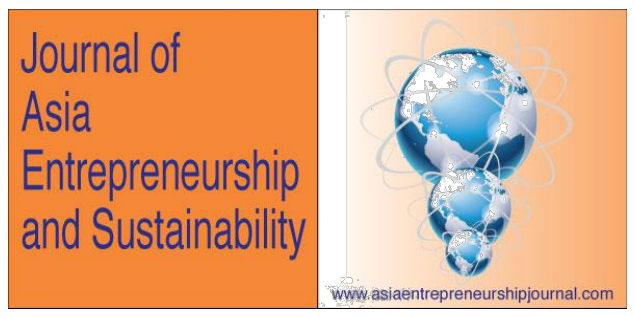

\begin{tabular}{|l|l|l|l|l|l|l|}
\hline $\begin{array}{l}\text { Appropriate } \\
\text { awards and } \\
\text { reinforcement }\end{array}$ & Male & 425 & 3.50 & 0.74 & 0.04 \\
\hline & Female & 162 & 3.56 & 0.81 & 0.06 \\
\hline & $\begin{array}{l}\text { Vision \& } \\
\text { Strategic intent }\end{array}$ & Male & 416 & 3.62 & 0.76 & 0.04 \\
\hline & Female & 169 & 3.72 & 0.78 & 0.06 \\
\hline & $\begin{array}{l}\text { Discretionary } \\
\text { time \& work }\end{array}$ & Male & 431 & 3.55 & 0.71 & 0.03 \\
\hline & $\begin{array}{l}\text { Total } \\
\text { Multi- } \\
\text { disciplinary } \\
\text { team }\end{array}$ & Female & 162 & 3.56 & 0.73 & 0.06 \\
\hline & Total & 593 & 3.55 & 0.71 & 0.03 \\
\hline & Male & 438 & 3.48 & 0.76 & 0.03 \\
\hline & Fmpowered / & 607 & 3.48 & 0.79 & 0.03 \\
\hline
\end{tabular}

Page 25

(c) 2019 Journal of Asia Entrepreneurship and Sustainability Vol XV, Iss 1, June 2019 RossiSmith Academic Publications, Oxford/London UK, www.publicationsales.com 


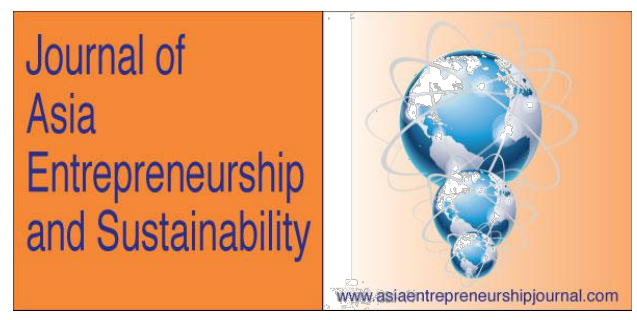

\begin{tabular}{|l|l|l|l|l|l|l|}
\hline & $\begin{array}{l}\text { Resource } \\
\text { availability and } \\
\text { accessibility }\end{array}$ & Male & 426 & 3.32 & 0.75 & 0.04 \\
\hline & Female & 163 & 3.34 & 0.70 & 0.06 \\
\hline & $\begin{array}{l}\text { Continuous \& } \\
\text { Cross- } \\
\text { functional } \\
\text { learning }\end{array}$ & Male & 589 & 3.33 & 0.74 & 0.03 \\
\hline & 411 & 3.52 & 0.69 & 0.03 \\
\hline & $\begin{array}{l}\text { Strong } \\
\text { customer } \\
\text { orientation }\end{array}$ & Female & 163 & 3.58 & 0.71 & 0.06 \\
\hline $\begin{array}{l}\text { Total } \\
\text { organizational } \\
\text { structure \& }\end{array}$ & 574 & 3.54 & 0.70 & 0.03 \\
\hline & Fale & 436 & 3.79 & 0.74 & 0.04 \\
\hline Total & 604 & 3.80 & 0.73 & 0.03 \\
\hline
\end{tabular}

Page 26

(C) 2019 Journal of Asia Entrepreneurship and Sustainability Vol XV, Iss 1, June 2019 RossiSmith Academic Publications, Oxford/London UK, www.publicationsales.com 


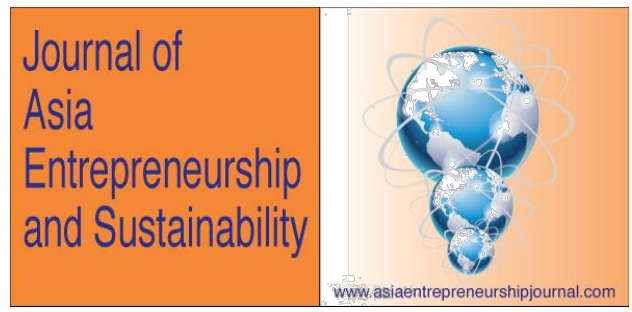

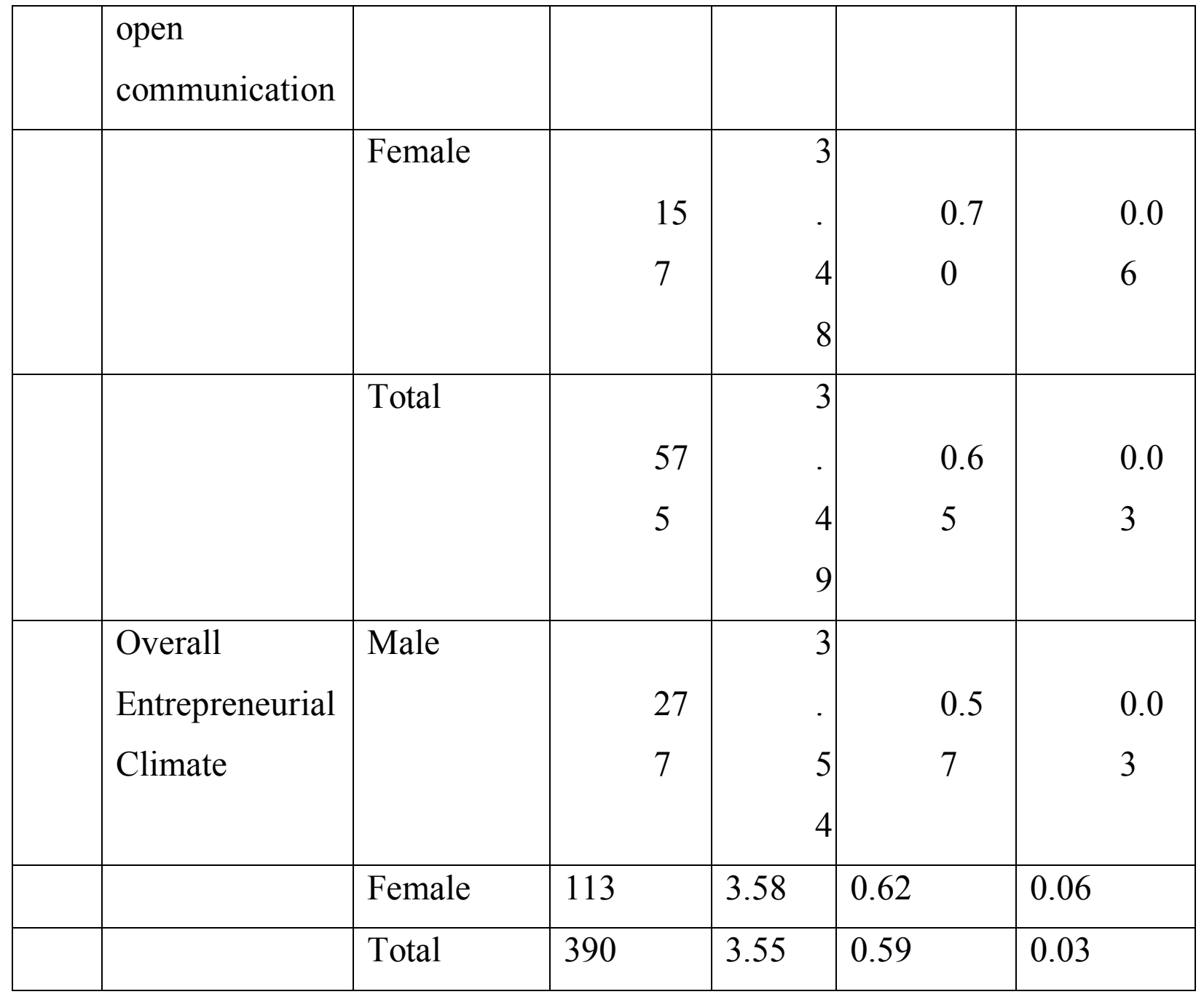

Some of the attributes of the employees such as gender, seniority in the management level, age-group, etc. may affect their perception related to entrepreneurial climate. ANOVA test is used to test these hypotheses.

Page 27

(C) 2019 Journal of Asia Entrepreneurship and Sustainability Vol XV, Iss 1, June 2019 RossiSmith Academic Publications, Oxford/London UK, www.publicationsales.com 


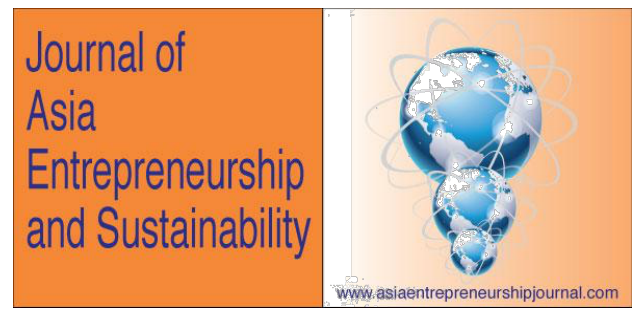

\section{II.1: Impact of gender on employees' perception related to entrepreneurial climate:}

$\mathrm{H}_{02}$ : Gender of the employees does not have any impact on their perception related to entrepreneurial climate.

$\mathrm{H}_{12}$ : Gender of the employees has an impact on their perception related to entrepreneurial climate.

\section{Table 3: Impact of Gender on Employees' Perception on Entrepreneurial Climate:}

The T-statistics shows that the difference across the gender is statistically not significant as $\mathrm{P}>0.05$ on all the 13 parameters. Thus it can be concluded that gender of the respondent does not impact the employees' perception related to entrepreneurial climate.

Page 28

(C) 2019 Journal of Asia Entrepreneurship and Sustainability Vol XV, Iss 1, June 2019 RossiSmith Academic Publications, Oxford/London UK, www.publicationsales.com 


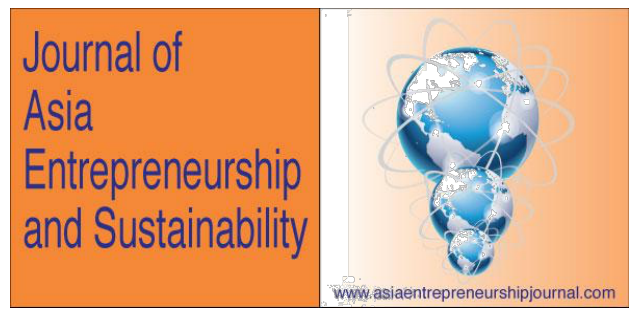

\section{II.2: Impact of Age-group on Employees' Perception on Entrepreneurial}

\section{Climate:}

$\mathrm{H}_{03}$ : Age group of the employees does not have any impact on their perception related to entrepreneurial climate.

$\mathrm{H}_{13}$ : Age group of the employees has an impact on their perception related to entrepreneurial climate.

Table 4: Impact of Age-group on Employees' Perception on Entrepreneurial Climate:

\begin{tabular}{|l|l|l|l|l|l|l|}
\hline $\begin{array}{l}\text { Sr. } \\
\text { No }\end{array}$ & Parameter & Categories & Number & Mean & $\begin{array}{l}\text { Std. } \\
\text { Dev. }\end{array}$ & Std. Error \\
\hline $\begin{array}{l}\text { Eal } \\
\text { leadership }\end{array}$ & $\begin{array}{l}30 \text { to } 40 \\
\text { Yrs }\end{array}$ & 202 & 3.55 & .76 & .05 \\
\hline & $40+$ Yrs & 61 & 3.85 & .77 & .09 \\
\hline & Total & 514 & 3.59 & .74 & .03 \\
\hline & $\begin{array}{l}\text { Management } \\
\text { support }\end{array}$ & $<29$ Yrs & 256 & 3.53 & .64 & .04 \\
\hline
\end{tabular}

Page 29

(c) 2019 Journal of Asia Entrepreneurship and Sustainability Vol XV, Iss 1, June 2019 RossiSmith Academic Publications, Oxford/London UK, www.publicationsales.com 


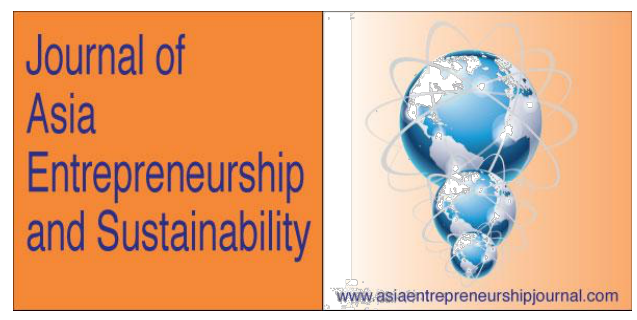

\begin{tabular}{|c|c|c|c|c|c|}
\hline & $\begin{array}{l}30 \text { to } 40 \\
\text { Yrs }\end{array}$ & 199 & 3.55 & .63 & .04 \\
\hline & $40+$ Yrs & 60 & 3.78 & .68 & .08 \\
\hline & Total & 515 & 3.57 & .64 & .02 \\
\hline $\begin{array}{l}\text { Sponsorship } \\
\text { (champion) }\end{array}$ & $<29$ Yrs & 257 & 3.37 & .73 & .04 \\
\hline & $\begin{array}{l}30 \text { to } 40 \\
\text { Yrs }\end{array}$ & 208 & 3.29 & .81 & .05 \\
\hline & $40+$ Yrs & 61 & 3.46 & .76 & .09 \\
\hline & Total & 526 & 3.35 & .77 & .03 \\
\hline $\begin{array}{l}\text { Tolerance } \\
\text { for risk \& } \\
\text { failure }\end{array}$ & $<29$ Yrs & 255 & 3.43 & .64 & .04 \\
\hline & $\begin{array}{l}30 \text { to } 40 \\
\text { Yrs }\end{array}$ & 204 & 3.45 & .62 & .04 \\
\hline & $40+$ Yrs & 62 & 3.64 & .73 & .09 \\
\hline & Total & 521 & 3.46 & .65 & .02 \\
\hline $\begin{array}{l}\text { Encourage- } \\
\text { ment to New } \\
\text { ideas }\end{array}$ & $<29$ Yrs & 239 & 3.48 & .68 & .04 \\
\hline
\end{tabular}

Page 30

(C) 2019 Journal of Asia Entrepreneurship and Sustainability Vol XV, Iss 1, June 2019 RossiSmith Academic Publications, Oxford/London UK, www.publicationsales.com 


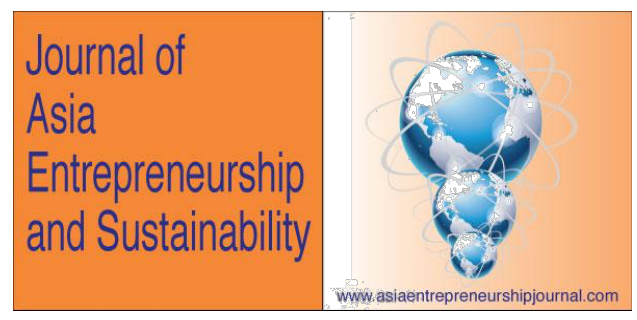

\begin{tabular}{|l|l|l|l|l|l|l|}
\hline & & $\begin{array}{l}30 \text { to } 40 \\
\text { Yrs }\end{array}$ & 201 & 3.47 & .74 & .05 \\
\hline & $40+$ yrs & 59 & 3.68 & .74 & .09 \\
\hline & Total & 499 & 3.50 & .71 & .03 \\
\hline $\begin{array}{l}\text { Appropriate } \\
\text { awards and } \\
\text { reinforceme } \\
\text { nt }\end{array}$ & $<29$ Yrs & 250 & 3.53 & .74 & .04 \\
\hline & $\begin{array}{l}30 \text { to } 40 \\
\text { Yrs }\end{array}$ & 202 & 3.54 & .77 & .05 \\
\hline & $40+$ Yrs & 55 & 3.68 & .78 & .10 \\
\hline & Total & 507 & 3.55 & .75 & .03 \\
\hline $\begin{array}{l}\text { Strategic } \\
\text { intent }\end{array}$ & $<29$ Yrs & 260 & 3.65 & .72 & .04 \\
\hline & 30 to 40 & 200 & 3.69 & .71 & .05 \\
\hline & Yrs & $40+$ yrs & 60 & 400 & .75 & .09 \\
\hline & Total & 520 & 3.70 & .73 & .03 \\
\hline
\end{tabular}

Page 31

(C) 2019 Journal of Asia Entrepreneurship and Sustainability Vol XV, Iss 1, June 2019 RossiSmith Academic Publications, Oxford/London UK, www.publicationsales.com 


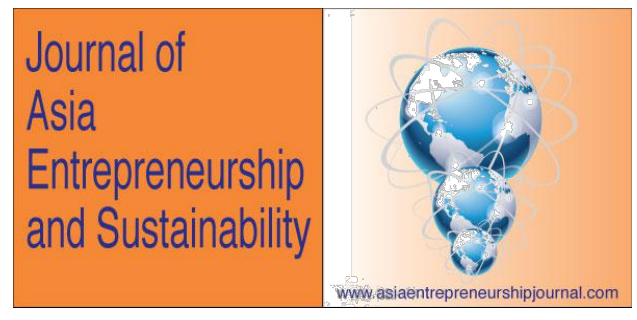

\begin{tabular}{|l|l|l|l|l|l|l|}
\hline $\begin{array}{l}\text { Discretionar } \\
\text { y time \& } \\
\text { work }\end{array}$ & $<29$ Yrs & 254 & 3.49 & .66 & .04 \\
\hline & $\begin{array}{l}30 \text { to } 40 \\
\text { Yrs }\end{array}$ & 199 & 3.55 & .74 & .05 \\
\hline & $40+$ Yrs & 61 & 3.75 & .78 & .10 \\
\hline $\begin{array}{l}\text { Empowered } \\
\text { disciplinary } \\
\text { team }\end{array}$ & Total & 514 & 3.54 & .71 & .03 \\
\hline & $\begin{array}{l}\text { Multi- } \\
\text { drs }\end{array}$ & 258 & 3.36 & .78 & .04 \\
\hline $\begin{array}{l}\text { Resource } \\
\text { availability } \\
\text { accessibility }\end{array}$ & $\begin{array}{l}<0 \text { to } 40 \\
\text { Yrs }\end{array}$ & 210 & 3.44 & .78 & .05 \\
\hline & $\begin{array}{l}\text { Total } \\
\text { ars }\end{array}$ & 248 & 3.29 & .72 & .04 \\
\hline & 61 & 3.62 & .85 & .10 \\
\hline
\end{tabular}

Page 32

(C) 2019 Journal of Asia Entrepreneurship and Sustainability Vol XV, Iss 1, June 2019 RossiSmith Academic Publications, Oxford/London UK, www.publicationsales.com 


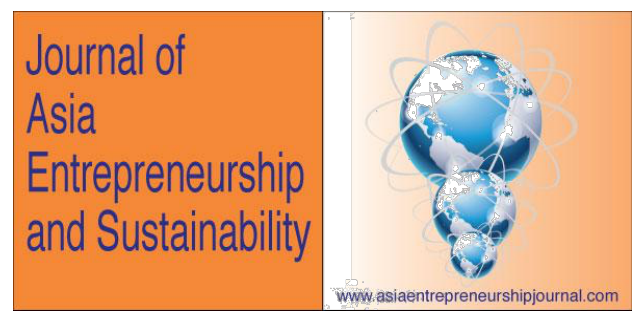

\begin{tabular}{|c|c|c|c|c|c|}
\hline & $\begin{array}{l}30 \text { to } 40 \\
\text { Yrs }\end{array}$ & 202 & 3.37 & .79 & .05 \\
\hline & $40+$ Yrs & 60 & 3.38 & .87 & .11 \\
\hline & Total & 510 & 3.34 & .76 & .03 \\
\hline $\begin{array}{l}\text { Continuous } \\
\& \text { Cross- } \\
\text { functional } \\
\text { learning }\end{array}$ & $<29$ Yrs & 246 & 3.52 & .66 & .04 \\
\hline & $\begin{array}{l}30 \text { to } 40 \\
\text { Yrs }\end{array}$ & 203 & 3.60 & .72 & .05 \\
\hline & $40+$ Yrs & 56 & 3.76 & .77 & .10 \\
\hline & Total & 505 & 3.58 & .70 & .03 \\
\hline $\begin{array}{l}\text { Strong } \\
\text { customer } \\
\text { orientation }\end{array}$ & $<29$ Yrs & 256 & 3.77 & .73 & .04 \\
\hline & $\begin{array}{l}30 \text { to } 40 \\
\text { Yrs }\end{array}$ & 207 & 3.89 & .73 & .05 \\
\hline & $40+$ Yrs & 62 & 4.00 & .74 & .09 \\
\hline & Total & 525 & 3.84 & .73 & .03 \\
\hline
\end{tabular}

Page 33

(C) 2019 Journal of Asia Entrepreneurship and Sustainability Vol XV, Iss 1, June 2019 RossiSmith Academic Publications, Oxford/London UK, www.publicationsales.com 


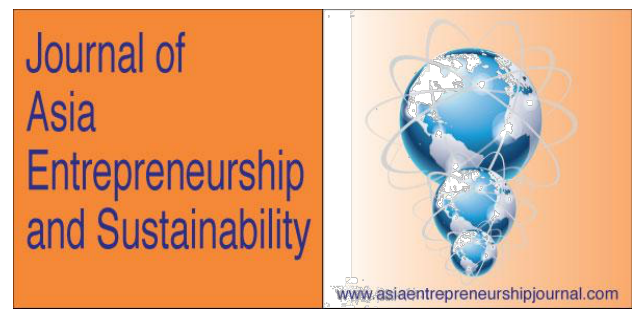

\begin{tabular}{|l|l|l|l|l|l|l|}
\hline $\begin{array}{l}\text { Flat } \\
\text { organization } \\
\text { al structure } \\
\text { \& open } \\
\text { communicati } \\
\text { on }\end{array}$ & $<29$ Yrs & 242 & 3.53 & .59 & .03 \\
\hline & $\begin{array}{l}30 \text { to } 40 \\
\text { Yrs }\end{array}$ & 203 & 3.52 & .67 & .04 \\
\hline & $40+$ Yrs & 60 & 3.63 & .72 & .09 \\
\hline $\begin{array}{l}\text { Overall } \\
\text { ial Climate }\end{array}$ & Total & 505 & 3.54 & .641 & .02 \\
\hline & $\begin{array}{l}<2 \text { Yrs } \\
\text { Yrs }\end{array}$ & 172 & 3.52 & .58 & .04 \\
\hline & $40+$ Yrs & 38 & 3.71 & .75 & .12 \\
\hline & Total & 367 & 3.54 & .60 & .03 \\
\hline & 157 & 3.53 & .58 & .04 \\
\hline
\end{tabular}

The T-statistics shows that there is significant difference across the three categories of age groups in five out of the total 13 parameters. These are Entrepreneurial

Page 34

(C) 2019 Journal of Asia Entrepreneurship and Sustainability Vol XV, Iss 1, June 2019

RossiSmith Academic Publications, Oxford/London UK, www.publicationsales.com 


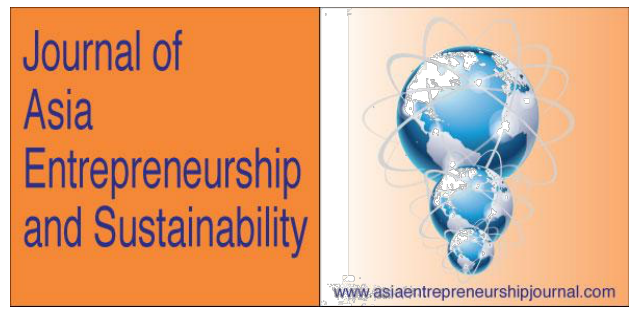

leadership, Management support, Vision \& Strategic intent, Discretionary time \& work and Strong customer orientation. The mean of the age-group $40+$ is significantly higher in all these parameters.

\section{II.3: Impact of Seniority in Management Level on Employees' Perception on Entrepreneurial Climate:}

$\mathrm{H}_{04}$ : Seniority in management level of the employees does not have any impact on their perception related to entrepreneurial climate.

$\mathrm{H}_{14}$ : Seniority in management level of the employees has an impact on their perception related to entrepreneurial climate.

Table 5: Impact of Seniority in Management Level on Employees' Perception on Entrepreneurial Climate:

\begin{tabular}{|r|l|l|l|l|l|l|}
\hline Sr. No & Parameter & Categories & Number & Mean & $\begin{array}{l}\text { Std. } \\
\text { Dev. }\end{array}$ & $\begin{array}{l}\text { Std. } \\
\text { Error }\end{array}$ \\
\hline 1 & $\begin{array}{l}\text { Entrepreneurial } \\
\text { leadership }\end{array}$ & $\begin{array}{l}\text { Top/ Senior } \\
\text { level }\end{array}$ & 115 & 3.52 & 0.78 & 0.07 \\
\hline & & Middle level & 279 & 3.65 & 0.69 & 0.04 \\
\hline & Other & 137 & 3.48 & 0.70 & 0.06 \\
\hline
\end{tabular}

Page 35

(c) 2019 Journal of Asia Entrepreneurship and Sustainability Vol XV, Iss 1, June 2019 RossiSmith Academic Publications, Oxford/London UK, www.publicationsales.com 


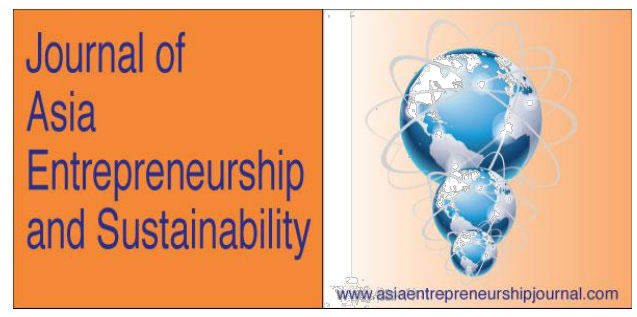

\begin{tabular}{|l|l|l|l|l|l|l|}
\hline 2 & $\begin{array}{l}\text { Management } \\
\text { support }\end{array}$ & $\begin{array}{l}\text { Top/ Senior } \\
\text { level }\end{array}$ & 110 & 3.57 & 0.70 & 0.07 \\
\hline & Middle level & 281 & 3.60 & 0.62 & 0.04 \\
\hline & Other & 134 & 3.41 & 0.64 & 0.05 \\
\hline 3 & $\begin{array}{l}\text { Sponsorship } \\
\text { (champion) }\end{array}$ & $\begin{array}{l}\text { Top/ Senior } \\
\text { level }\end{array}$ & 525 & 3.55 & 0.64 & 0.03 \\
\hline & Middle level & 285 & 3.41 & 0.76 & 0.05 \\
\hline & $\begin{array}{l}\text { Tolerance for } \\
\text { risk \& failure }\end{array}$ & $\begin{array}{l}\text { Top/ Senior } \\
\text { level }\end{array}$ & 916 & 3.27 & 0.98 & 0.09 \\
\hline & Other & 136 & 3.25 & 0.82 & 0.07 \\
\hline & $\begin{array}{l}\text { Total } \\
\text { to New ideas }\end{array}$ & $\begin{array}{l}\text { Top/ Senior } \\
\text { level }\end{array}$ & 113 & 3.57 & 0.64 & 0.06 \\
\hline & Middle level & 276 & 3.56 & 0.69 & 0.04 \\
\hline & Other & 139 & 3.33 & 0.56 & 0.05 \\
\hline & Total & 517 & 3.51 & 0.68 & 0.03 \\
\hline & & 505 & 3.46 & 0.64 & 0.03 \\
\hline
\end{tabular}

Page 36

(C) 2019 Journal of Asia Entrepreneurship and Sustainability Vol XV, Iss 1, June 2019 RossiSmith Academic Publications, Oxford/London UK, www.publicationsales.com 


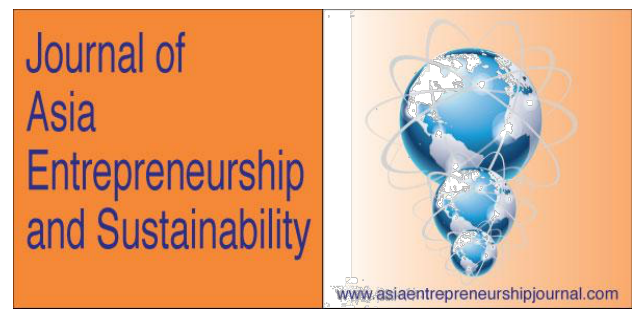

\begin{tabular}{|l|l|l|l|l|l|l|}
\hline 6 & $\begin{array}{l}\text { Appropriate } \\
\text { awards and } \\
\text { reinforcement }\end{array}$ & $\begin{array}{l}\text { Top/ Senior } \\
\text { level }\end{array}$ & 112 & 3.43 & 0.83 & 0.08 \\
\hline & & Middle level & 281 & 3.60 & 071 & 0.04 \\
\hline & Other & 126 & 3.43 & 0.78 & 0.07 \\
\hline 7 & $\begin{array}{l}\text { Vision \& } \\
\text { Strategic intent }\end{array}$ & $\begin{array}{l}\text { Top/ Senior } \\
\text { level }\end{array}$ & 109 & 3.54 & 0.92 & 0.09 \\
\hline & Middle level & 274 & 3.70 & 0.71 & 0.04 \\
\hline 8 & $\begin{array}{l}\text { Discretionary } \\
\text { time \& work }\end{array}$ & $\begin{array}{l}\text { Top/ Senior } \\
\text { level }\end{array}$ & 137 & 3.64 & 0.74 & 0.06 \\
\hline & $\begin{array}{l}\text { Other } \\
\text { Tisciplinary } \\
\text { team }\end{array}$ & $\begin{array}{l}\text { Middle level } \\
\text { Eulti- }\end{array}$ & 277 & 3.57 & 0.73 & 0.04 \\
\hline & $\begin{array}{l}\text { Other } \\
\text { level }\end{array}$ & 136 & 3.43 & 0.67 & 0.06 \\
\hline & Total & 526 & 3.57 & 0.71 & 0.03 \\
\hline & & 115 & 3.66 & 0.73 & 0.07 \\
\hline
\end{tabular}

Page 37

(C) 2019 Journal of Asia Entrepreneurship and Sustainability Vol XV, Iss 1, June 2019 RossiSmith Academic Publications, Oxford/London UK, www.publicationsales.com 


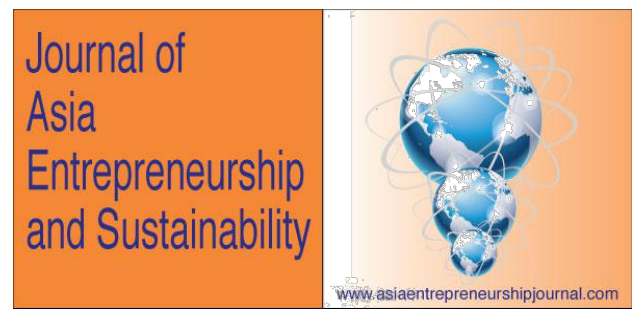

\begin{tabular}{|c|c|c|c|c|c|c|}
\hline & & Middle level & 285 & 3.49 & 0.79 & 0.05 \\
\hline & & Other & 139 & 3.35 & 0.82 & 0.07 \\
\hline & & Total & 539 & 3.49 & 0.79 & 0.03 \\
\hline \multirow[t]{4}{*}{10} & $\begin{array}{l}\text { Resource } \\
\text { availability and } \\
\text { accessibility }\end{array}$ & $\begin{array}{l}\text { Top/ Senior } \\
\text { level }\end{array}$ & 113 & 3.34 & 0.76 & 0.07 \\
\hline & & Middle level & 275 & 3.38 & 0.74 & 0.04 \\
\hline & & Other & 134 & 3.19 & 0.71 & 0.06 \\
\hline & & Total & 522 & 3.32 & 0.74 & 0.03 \\
\hline \multirow[t]{4}{*}{11} & $\begin{array}{l}\text { Continuous \& } \\
\text { Cross- } \\
\text { functional } \\
\text { learning }\end{array}$ & $\begin{array}{l}\text { Top/ Senior } \\
\text { level }\end{array}$ & 111 & 3.50 & 0.75 & 0.07 \\
\hline & & Middle level & 260 & 3.64 & 0.67 & 0.04 \\
\hline & & Other & 136 & 3.40 & 0.64 & 0.05 \\
\hline & & Total & 507 & 3.54 & 0.69 & 0.03 \\
\hline \multirow[t]{2}{*}{12} & $\begin{array}{l}\text { Strong } \\
\text { customer } \\
\text { orientation }\end{array}$ & $\begin{array}{l}\text { Top/ Senior } \\
\text { level }\end{array}$ & 116 & 3.65 & 0.74 & 0.07 \\
\hline & & Middle level & 284 & 3.87 & 0.69 & 0.04 \\
\hline
\end{tabular}

Page 38

(C) 2019 Journal of Asia Entrepreneurship and Sustainability Vol XV, Iss 1, June 2019 RossiSmith Academic Publications, Oxford/London UK, www.publicationsales.com 


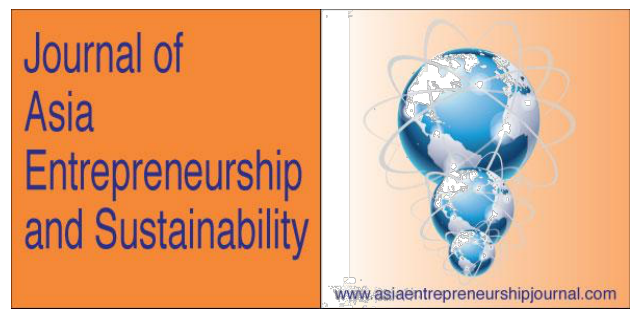

\begin{tabular}{|l|l|l|l|l|l|l|}
\hline & & Other & 138 & 3.82 & 0.73 & 0.06 \\
\hline 13 & $\begin{array}{l}\text { Total } \\
\text { organizational } \\
\text { structure \& } \\
\text { open } \\
\text { communication }\end{array}$ & $\begin{array}{l}\text { Top/ Senior } \\
\text { level }\end{array}$ & 538 & 3.81 & 0.72 & 0.03 \\
\hline & $\begin{array}{l}\text { Middle level } \\
\text { Nat }\end{array}$ & 262 & 3.57 & 0.61 & 0.04 \\
\hline & $\begin{array}{l}\text { Other } \\
\text { Entrepreneurial } \\
\text { Climate }\end{array}$ & $\begin{array}{l}\text { Top/ Senior } \\
\text { level }\end{array}$ & 134 & 3.40 & 0.65 & 0.06 \\
\hline & & 507 & 3.50 & 0.66 & 0.03 \\
\hline & Middle level & 188 & 3.56 & 0.60 & 0.04 \\
\hline & Other & 96 & 3.46 & 0.56 & 0.06 \\
\hline & Total & 347 & 3.57 & 0.59 & 0.03 \\
\hline
\end{tabular}

The T-statistics shows that employees' perception related to overall entrepreneurial climate is affected by their managerial level $(\mathrm{P}<0.05)$. The overall mean is higher for Top/ senior level managers. The difference across the managerial levels is

\section{Page 39}

(C) 2019 Journal of Asia Entrepreneurship and Sustainability Vol XV, Iss 1, June 2019 RossiSmith Academic Publications, Oxford/London UK, www.publicationsales.com 


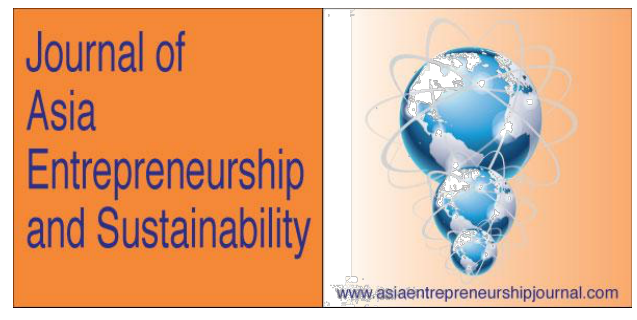

found out to be statistically significant in nine out of total 13 parameters. These are as follows:

1. Entrepreneurial leadership - The mean of Middle level managers is significantly high.

2. Management support - The mean of Middle level managers is significantly high.

3. Tolerance for risk \& failure - The mean of Top/ senior level managers is significantly high.

4. Encouragement to New ideas - The mean of Top/ senior level managers is significantly high.

5. Discretionary time \& work - The mean of Top/ senior level managers is significantly high.

6. Empowered / Multi-disciplinary team - The mean of Top/ senior level managers is significantly high.

7. Continuous \& Cross-functional learning - The mean of Middle level managers is significantly high.

8. Strong customer orientation - The mean of Middle level managers is significantly high. 


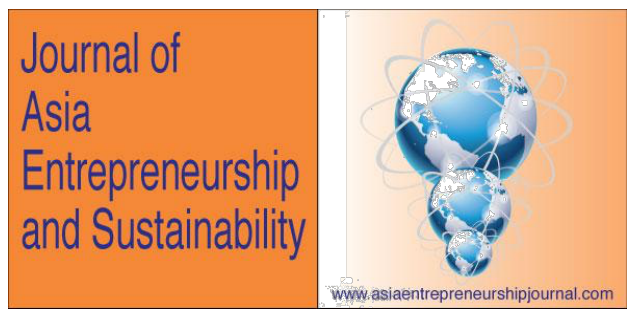

9. Flat organizational structure \& open communication - The mean of Middle level managers is significantly high.

It may thus be concluded that though overall mean is higher for Top/ senior level managers, it significantly differs across the parameters.

Objective III: To assess the impact of various organization related attributes such as size of the organization and the sector in which the organization is functioning on the entrepreneurial climate.

The existing literature shows that some of the organizational characteristics such as size, sector, etc. may influence the employees' perception related to entrepreneurial climate. The ANOVA test is used to get answers to these questions.

\section{III.1: Impact of Size of the Organization on Employees' Perception on Entrepreneurial Climate:}

$\mathrm{H}_{05}$ : Size of the organization (measured in terms of number of employees) does not have any impact on the employees perception related to entrepreneurial climate. $\mathrm{H}_{15}$ : Size of the organization (measured in terms of number of employees) has na impact on the employees perception related to entrepreneurial climate. 


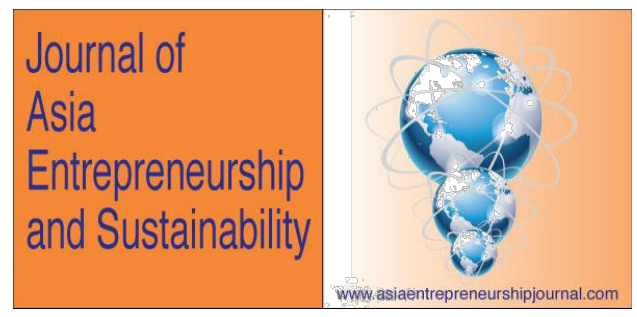

Table 6: Impact of Size of the Organization on Employees' Perception on Entrepreneurial Climate:

\begin{tabular}{|l|l|l|l|l|l|l|}
\hline $\begin{array}{l}\text { Sr. } \\
\text { No }\end{array}$ & Parameter & Categories & Number & Mean & $\begin{array}{l}\text { Std. } \\
\text { Dev. }\end{array}$ & $\begin{array}{l}\text { Std. } \\
\text { Error }\end{array}$ \\
\hline $\begin{array}{l}\text { Entrepreneuri } \\
\text { al leadership }\end{array}$ & Small $(<=50)$ & 38.00 & 3.51 & 0.85 & 0.14 \\
\hline & $\begin{array}{l}\text { Medium }(51- \\
200)\end{array}$ & 56.00 & 3.53 & 0.72 & 0.10 \\
\hline & $\begin{array}{l}\text { Large }(201+) \\
\text { support }\end{array}$ & 501.00 & 3.58 & 0.72 & 0.03 \\
\hline & $\begin{array}{l}\text { Total } \\
\text { Small }(<=50)\end{array}$ & $\begin{array}{l}595.00 \\
200)\end{array}$ & 3.57 & 0.73 & 0.03 \\
\hline & $\begin{array}{l}\text { Medium }(51- \\
\text { Large }(201+)\end{array}$ & 501.00 & 3.56 & 0.65 & 0.03 \\
\hline champion) & Total & 596.00 & 3.55 & 0.65 & 0.03 \\
\hline & $\begin{array}{l}\text { Small }(<=50) \\
\text { Medium }(51-\end{array}$ & 37.00 & 3.19 & 0.81 & 0.13 \\
\hline
\end{tabular}

Page 42

(C) 2019 Journal of Asia Entrepreneurship and Sustainability Vol XV, Iss 1, June 2019 RossiSmith Academic Publications, Oxford/London UK, www.publicationsales.com 


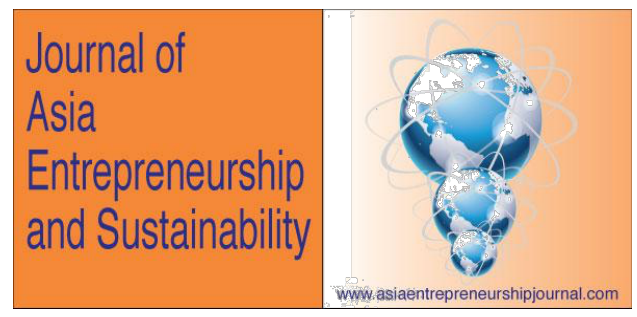

\begin{tabular}{|l|l|l|l|l|l|l|}
\hline & & Large $(201+)$ & 512.00 & 3.36 & 0.82 & 0.04 \\
\hline & $\begin{array}{l}\text { Total } \\
\text { risk \& failure }\end{array}$ & 606.00 & 3.35 & 0.82 & 0.03 \\
\hline & $\begin{array}{l}\text { Medium }(51- \\
200)\end{array}$ & 39.00 & 3.38 & 0.55 & 0.09 \\
\hline & Large $(201+)$ & 481.00 & 3.48 & 0.64 & 0.03 \\
\hline $\begin{array}{l}\text { Encourageme } \\
\text { nt to New } \\
\text { ideas }\end{array}$ & Total & 576.00 & 3.46 & 0.64 & 0.03 \\
\hline & $\begin{array}{l}\text { Small }(<=50) \\
\text { Medium }(51-\end{array}$ & 36.00 & 3.44 & 0.63 & 0.10 \\
\hline $\begin{array}{l}\text { Appropriate } \\
\text { awards and } \\
\text { reinforcement }\end{array}$ & $\begin{array}{l}\text { Small }(<=50) \\
200)\end{array}$ & Large $(201+)$ & 491.00 & 3.51 & 0.69 & 0.03 \\
\hline & Total & 580.00 & 3.50 & 0.69 & 0.03 \\
\hline & 53.00 & 3.37 & 0.80 & 0.13 \\
\hline
\end{tabular}

Page 43

(C) 2019 Journal of Asia Entrepreneurship and Sustainability Vol XV, Iss 1, June 2019 RossiSmith Academic Publications, Oxford/London UK, www.publicationsales.com 


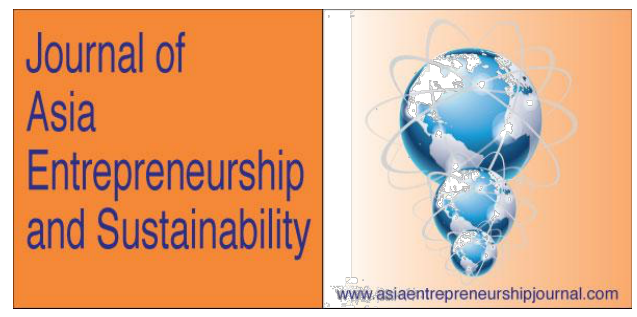

\begin{tabular}{|c|c|c|c|c|c|}
\hline & Large $(201+)$ & 499.00 & 3.54 & 0.74 & 0.03 \\
\hline & Total & 587.00 & 3.51 & 0.76 & 0.03 \\
\hline $\begin{array}{l}\text { Vision \& } \\
\text { Strategic } \\
\text { intent }\end{array}$ & Small $(<=50)$ & 38.00 & 3.48 & 0.86 & 0.14 \\
\hline & $\begin{array}{l}\text { Medium (51 - } \\
200)\end{array}$ & 59.00 & 3.62 & 0.68 & 0.09 \\
\hline & Large $(201+)$ & 490.00 & 3.66 & 0.77 & 0.03 \\
\hline & Total & 587.00 & 3.65 & 0.77 & 0.03 \\
\hline $\begin{array}{l}\text { Discretionary } \\
\text { time \& work }\end{array}$ & Small $(<=50)$ & 35.00 & 3.60 & 0.60 & 0.10 \\
\hline & $\begin{array}{l}\text { Medium (51- } \\
200)\end{array}$ & 55.00 & 3.44 & 0.69 & 0.09 \\
\hline & Large $(201+)$ & 505.00 & 3.56 & 0.72 & 0.03 \\
\hline & Total & 595.00 & 3.55 & 0.71 & 0.03 \\
\hline $\begin{array}{l}\text { Empowered / } \\
\text { Multi- } \\
\text { disciplinary } \\
\text { team }\end{array}$ & Small $(<=50)$ & 39.00 & 3.52 & 0.78 & 0.13 \\
\hline
\end{tabular}

Page 44

(C) 2019 Journal of Asia Entrepreneurship and Sustainability Vol XV, Iss 1, June 2019 RossiSmith Academic Publications, Oxford/London UK, www.publicationsales.com 


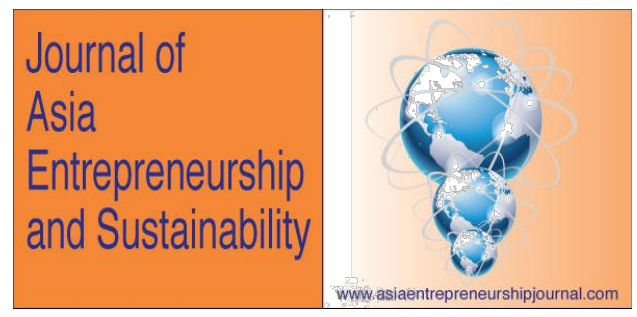

\begin{tabular}{|c|c|c|c|c|c|}
\hline & $\begin{array}{l}\text { Medium (51- } \\
200)\end{array}$ & 59.00 & 3.40 & 0.72 & 0.09 \\
\hline & Large $(201+)$ & 511.00 & 3.49 & 0.80 & 0.04 \\
\hline & Total & 609.00 & 3.48 & 0.79 & 0.03 \\
\hline $\begin{array}{l}\text { Resource } \\
\text { availability } \\
\text { and } \\
\text { accessibility }\end{array}$ & Small $(<=50)$ & 34.00 & 3.22 & 0.73 & 0.13 \\
\hline & $\begin{array}{l}\text { Medium (51- } \\
\text { 200) }\end{array}$ & 56.00 & 3.27 & 0.78 & 0.10 \\
\hline & Large $(201+)$ & 501.00 & 3.34 & 0.73 & 0.03 \\
\hline & Total & 591.00 & 3.33 & 0.74 & 0.03 \\
\hline $\begin{array}{l}\text { Continuous \& } \\
\text { Cross- } \\
\text { functional } \\
\text { learning }\end{array}$ & Small $(<=50)$ & 38.00 & 3.64 & 0.63 & 0.10 \\
\hline & $\begin{array}{l}\text { Medium }(51- \\
200)\end{array}$ & 55.00 & 3.56 & 0.61 & 0.08 \\
\hline & Large $(201+)$ & 482.00 & 3.53 & 0.71 & 0.03 \\
\hline & Total & 575.00 & 3.54 & 0.70 & 0.03 \\
\hline
\end{tabular}

Page 45

(C) 2019 Journal of Asia Entrepreneurship and Sustainability Vol XV, Iss 1, June 2019 RossiSmith Academic Publications, Oxford/London UK, www.publicationsales.com 


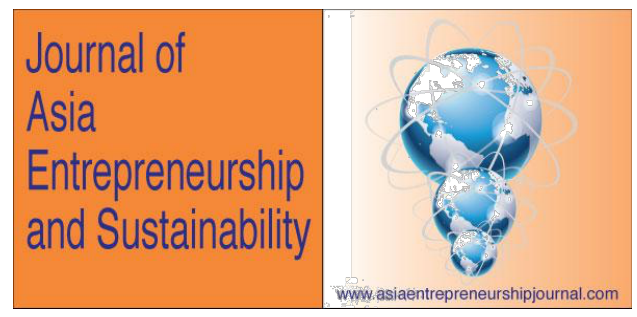

\begin{tabular}{|l|l|l|l|l|l|l|}
\hline $\begin{array}{l}\text { Strong } \\
\text { customer } \\
\text { orientation }\end{array}$ & Small $(<=50)$ & 39.00 & 3.59 & 0.71 & 0.11 \\
\hline & $\begin{array}{l}\text { Medium }(51- \\
200)\end{array}$ & 58.00 & 3.79 & 0.82 & 0.11 \\
\hline $\begin{array}{l}\text { Flat } \\
\text { organizational } \\
\text { structure \& } \\
\text { open } \\
\text { communicatio } \\
\mathrm{n}\end{array}$ & Sarge $(201+)$ & 509.00 & 3.82 & 0.72 & 0.03 \\
\hline & Total & 606.00 & 3.80 & 0.73 & 0.03 \\
\hline $\begin{array}{l}\text { Small }(<=50) \\
\text { al Climate }\end{array}$ & $\begin{array}{l}\text { Medium }(51- \\
200)\end{array}$ & Large $(201+)$ & 487.00 & 3.47 & 0.66 & 0.03 \\
\hline & Total & 577.00 & 3.49 & 0.65 & 0.03 \\
\hline & Small $(<=50)$ & 35.00 & 3.69 & 0.59 & 0.10 \\
\hline & 55.00 & 3.60 & 0.62 & 0.08 \\
\hline
\end{tabular}

Page 46

(C) 2019 Journal of Asia Entrepreneurship and Sustainability Vol XV, Iss 1, June 2019 RossiSmith Academic Publications, Oxford/London UK, www.publicationsales.com 


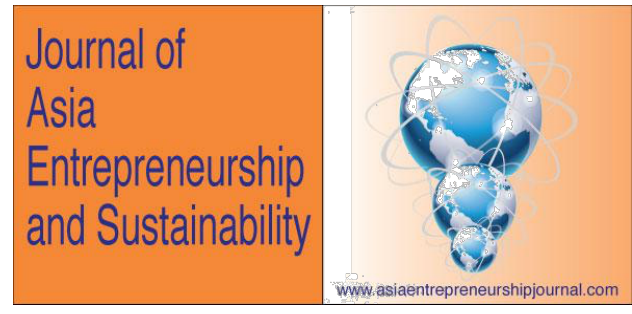

\begin{tabular}{|l|l|l|l|l|l|l|}
\hline & $\begin{array}{l}\text { Medium (51 - } \\
200)\end{array}$ & 36.00 & 3.53 & 0.55 & 0.09 \\
\hline & & Large (201+) & 333.00 & 3.56 & 0.59 & 0.03 \\
\hline & Total & 390.00 & 3.55 & 0.59 & 0.03 \\
\hline
\end{tabular}

The T-statistics shows that the difference across the size of the organization is statistically not significant as $\mathrm{P}>0.05$ on all the 13 parameters. Thus it can be concluded that the size of the organization does not impact the employees' perception related to entrepreneurial climate.

\section{III.2: Impact of Sector on Employees' Perception on Entrepreneurial}

\section{Climate:}

$\mathrm{H}_{06}$ : Sector of the organization does not have any impact on the employees perception related to entrepreneurial climate.

$\mathrm{H}_{16}$ : Sector of the organization has an impact on the employees perception related to entrepreneurial climate. 


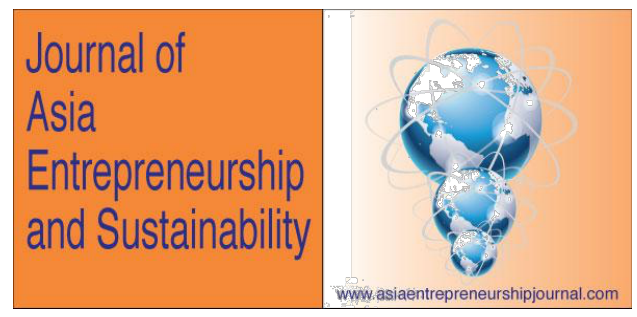

Table 7: Impact of Sector on Employees' Perception on Entrepreneurial

\section{Climate:}

\begin{tabular}{|c|c|c|c|c|c|c|}
\hline Sr. No & Parameter & Categories & Number & Mean & $\begin{array}{l}\text { Std. } \\
\text { Dev. }\end{array}$ & $\begin{array}{l}\text { Std. } \\
\text { Error }\end{array}$ \\
\hline \multirow[t]{5}{*}{1} & $\begin{array}{l}\text { Entrepreneurial } \\
\text { leadership }\end{array}$ & $\begin{array}{l}\text { IT \& IT } \\
\text { services }\end{array}$ & 200 & 3.50 & 0.65 & 0.05 \\
\hline & & $\begin{array}{l}\text { Mfg/ } \\
\text { engineering }\end{array}$ & 88 & 3.84 & 0.75 & 0.08 \\
\hline & & $\begin{array}{l}\text { Banking/ } \\
\text { finance }\end{array}$ & 130 & 3.55 & 0.76 & 0.07 \\
\hline & & Other & 121 & 3.43 & 0.78 & 0.07 \\
\hline & & Total & 539 & 3.55 & 0.74 & 0.03 \\
\hline \multirow[t]{5}{*}{2} & $\begin{array}{l}\text { Management } \\
\text { support }\end{array}$ & $\begin{array}{l}\text { IT \& IT } \\
\text { services }\end{array}$ & 193 & 3.52 & 0.60 & 0.04 \\
\hline & & $\begin{array}{l}\text { Mfg/ } \\
\text { engineering }\end{array}$ & 90 & 3.70 & 0.71 & 0.07 \\
\hline & & $\begin{array}{l}\text { Banking/ } \\
\text { finance }\end{array}$ & 133 & 3.51 & 0.65 & 0.06 \\
\hline & & Other & 122 & 3.48 & 0.68 & 0.06 \\
\hline & & Total & 538 & 3.54 & 0.65 & 0.03 \\
\hline
\end{tabular}

Page 48

(C) 2019 Journal of Asia Entrepreneurship and Sustainability Vol XV, Iss 1, June 2019

RossiSmith Academic Publications, Oxford/London UK, www.publicationsales.com 


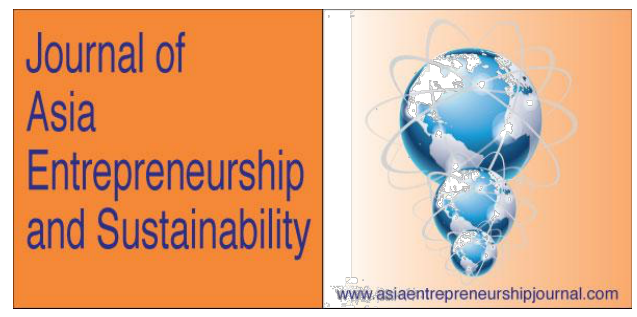

\begin{tabular}{|c|c|c|c|c|c|c|}
\hline \multirow[t]{5}{*}{3} & $\begin{array}{l}\text { Sponsorship } \\
\text { (champion) }\end{array}$ & $\begin{array}{l}\text { IT \& IT } \\
\text { services }\end{array}$ & 201 & 3.36 & 0.80 & 0.06 \\
\hline & & $\begin{array}{l}\text { Mfg/ } \\
\text { engineering }\end{array}$ & 92 & 3.45 & 0.73 & 0.08 \\
\hline & & $\begin{array}{l}\text { Banking/ } \\
\text { finance }\end{array}$ & 129 & 3.38 & 0.88 & 0.08 \\
\hline & & Other & 124 & 3.15 & 0.88 & 0.08 \\
\hline & & Total & 546 & 3.33 & 0.83 & 0.04 \\
\hline \multirow[t]{5}{*}{4} & $\begin{array}{l}\text { Tolerance for } \\
\text { risk \& failure }\end{array}$ & $\begin{array}{l}\text { IT \& IT } \\
\text { services }\end{array}$ & 192 & 3.48 & 0.55 & 0.04 \\
\hline & & $\begin{array}{l}\text { Mfg/ } \\
\text { engineering }\end{array}$ & 89 & 3.53 & 0.68 & 0.07 \\
\hline & & $\begin{array}{l}\text { Banking/ } \\
\text { finance }\end{array}$ & 127 & 3.42 & 0.68 & 0.06 \\
\hline & & Other & 112 & 3.42 & 0.66 & 0.06 \\
\hline & & Total & 520 & 3.46 & 0.63 & 0.03 \\
\hline \multirow[t]{2}{*}{5} & $\begin{array}{l}\text { Encouragement } \\
\text { to New ideas }\end{array}$ & $\begin{array}{l}\text { IT \& IT } \\
\text { services }\end{array}$ & 191 & 3.44 & 0.64 & 0.05 \\
\hline & & $\begin{array}{l}\text { Mfg/ } \\
\text { engineering }\end{array}$ & 92 & 3.67 & 0.73 & 0.08 \\
\hline
\end{tabular}

Page 49

(C) 2019 Journal of Asia Entrepreneurship and Sustainability Vol XV, Iss 1, June 2019 RossiSmith Academic Publications, Oxford/London UK, www.publicationsales.com 


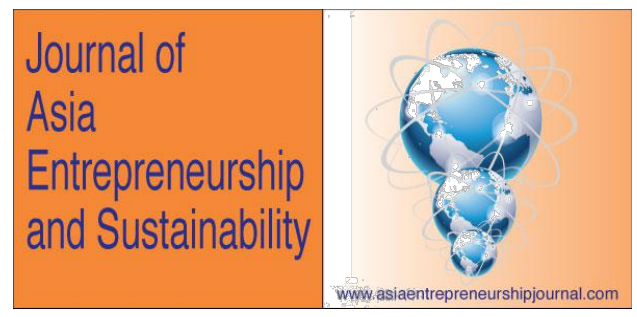

\begin{tabular}{|c|c|c|c|c|c|c|}
\hline & & $\begin{array}{l}\text { Banking/ } \\
\text { finance }\end{array}$ & 122 & 3.53 & 0.69 & 0.06 \\
\hline & & Other & 119 & 3.44 & 0.69 & 0.06 \\
\hline & & Total & 524 & 3.50 & 0.68 & 0.03 \\
\hline \multirow[t]{5}{*}{6} & $\begin{array}{l}\text { Appropriate } \\
\text { awards and } \\
\text { reinforcement }\end{array}$ & $\begin{array}{l}\text { IT \& IT } \\
\text { services }\end{array}$ & 195 & 3.47 & 0.68 & 0.05 \\
\hline & & $\begin{array}{l}\text { Mfg/ } \\
\text { engineering }\end{array}$ & 88 & 3.65 & 0.72 & 0.08 \\
\hline & & $\begin{array}{l}\text { Banking/ } \\
\text { finance }\end{array}$ & 126 & 3.58 & 0.76 & 0.07 \\
\hline & & Other & 118 & 3.32 & 0.89 & 0.08 \\
\hline & & Total & 527 & 3.50 & 0.76 & 0.03 \\
\hline \multirow[t]{4}{*}{7} & $\begin{array}{l}\text { Vision \& } \\
\text { Strategic intent }\end{array}$ & $\begin{array}{l}\text { IT \& IT } \\
\text { services }\end{array}$ & 184 & 3.60 & 0.70 & 0.05 \\
\hline & & $\begin{array}{l}\mathrm{Mfg} / \\
\text { engineering }\end{array}$ & 92 & 3.90 & 0.77 & 0.08 \\
\hline & & $\begin{array}{l}\text { Banking/ } \\
\text { finance }\end{array}$ & 129 & 3.64 & 0.76 & 0.07 \\
\hline & & Other & 124 & 3.46 & 0.83 & 0.07 \\
\hline
\end{tabular}

Page 50

(C) 2019 Journal of Asia Entrepreneurship and Sustainability Vol XV, Iss 1, June 2019 RossiSmith Academic Publications, Oxford/London UK, www.publicationsales.com 


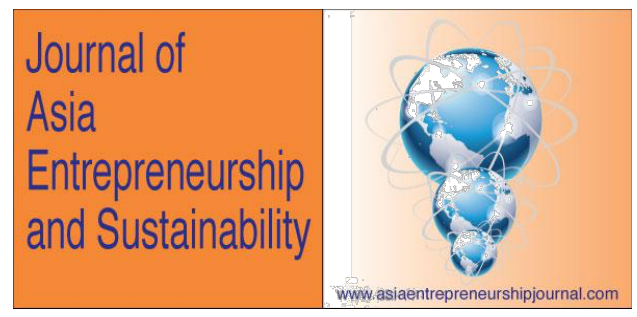

\begin{tabular}{|c|c|c|c|c|c|c|}
\hline & & Total & 529 & 3.63 & 0.77 & 0.03 \\
\hline \multirow[t]{5}{*}{8} & $\begin{array}{l}\text { Discretionary } \\
\text { time \& work }\end{array}$ & $\begin{array}{l}\text { IT \& IT } \\
\text { services }\end{array}$ & 195 & 3.54 & 0.70 & 0.05 \\
\hline & & $\begin{array}{l}\text { Mfg/ } \\
\text { engineering }\end{array}$ & 90 & 3.71 & 0.76 & 0.08 \\
\hline & & $\begin{array}{l}\text { Banking/ } \\
\text { finance }\end{array}$ & 129 & 3.47 & 0.72 & 0.06 \\
\hline & & Other & 122 & 3.51 & 0.69 & 0.06 \\
\hline & & Total & 536 & 3.55 & 0.71 & 0.03 \\
\hline \multirow[t]{4}{*}{9} & $\begin{array}{l}\text { Empowered / } \\
\text { Multi- } \\
\text { disciplinary } \\
\text { team }\end{array}$ & $\begin{array}{l}\text { IT \& IT } \\
\text { services }\end{array}$ & 198 & 3.51 & 0.78 & 0.06 \\
\hline & & $\begin{array}{l}\text { Mfg/ } \\
\text { engineering }\end{array}$ & 90 & 3.63 & 0.75 & 0.08 \\
\hline & & $\begin{array}{l}\text { Banking/ } \\
\text { finance }\end{array}$ & 132 & 3.44 & 0.82 & 0.07 \\
\hline & & Other & 130 & 3.40 & 0.80 & 0.07 \\
\hline
\end{tabular}

Page 51

(C) 2019 Journal of Asia Entrepreneurship and Sustainability Vol XV, Iss 1, June 2019 RossiSmith Academic Publications, Oxford/London UK, www.publicationsales.com 


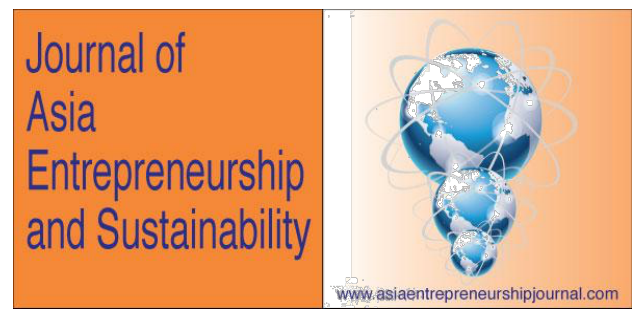

\begin{tabular}{|l|l|l|l|l|l|l|}
\hline 10 & $\begin{array}{l}\text { Resource } \\
\text { availability and } \\
\text { accessibility }\end{array}$ & $\begin{array}{l}\text { IT \& IT } \\
\text { services }\end{array}$ & 550 & 3.49 & 0.79 & 0.03 \\
\hline & & $\begin{array}{l}\text { Mfg/ } \\
\text { engineering }\end{array}$ & 92 & 3.45 & 0.77 & 0.08 \\
\hline & $\begin{array}{l}\text { Banking/ } \\
\text { finance }\end{array}$ & 131 & 3.37 & 0.74 & 0.06 \\
\hline & $\begin{array}{l}\text { Other } \\
\text { Cross-functional } \\
\text { learning }\end{array}$ & $\begin{array}{l}\text { IT \& IT } \\
\text { services }\end{array}$ & 122 & 3.24 & 0.76 & 0.07 \\
\hline & $\begin{array}{l}\text { Total } \\
\text { Continuous \& }\end{array}$ & $\begin{array}{l}\text { Mfg/ } \\
\text { engineering }\end{array}$ & 834 & 3.33 & 0.74 & 0.03 \\
\hline & $\begin{array}{l}\text { Banking/ } \\
\text { finance }\end{array}$ & 123 & 3.49 & 0.75 & 0.07 \\
\hline & Other & 121 & 3.44 & 0.71 & 0.06 \\
\hline & Total & 517 & 3.51 & 0.70 & 0.03 \\
\hline
\end{tabular}

Page 52

(C) 2019 Journal of Asia Entrepreneurship and Sustainability Vol XV, Iss 1, June 2019 RossiSmith Academic Publications, Oxford/London UK, www.publicationsales.com 


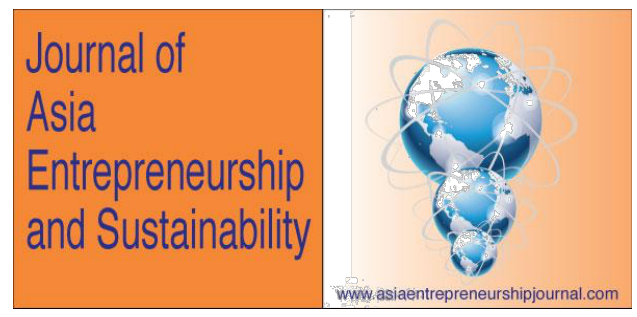

\begin{tabular}{|l|l|l|l|l|l|l|}
\hline 12 & $\begin{array}{l}\text { Strong customer } \\
\text { orientation }\end{array}$ & $\begin{array}{l}\text { IT \& IT } \\
\text { services }\end{array}$ & 199 & 3.81 & 0.65 & 0.05 \\
\hline & $\begin{array}{l}\text { Mfg/ } \\
\text { engineering }\end{array}$ & 93 & 3.93 & 0.79 & 0.08 \\
\hline & $\begin{array}{l}\text { Banking/ } \\
\text { finance }\end{array}$ & 129 & 3.72 & 0.85 & 0.07 \\
\hline & Other & 126 & 3.69 & 0.69 & 0.06 \\
\hline 13 & $\begin{array}{l}\text { Flat } \\
\text { organizational } \\
\text { structure \& } \\
\text { open } \\
\text { communication }\end{array}$ & $\begin{array}{l}\text { IT \& IT } \\
\text { services }\end{array}$ & 547 & 3.78 & 0.73 & 0.03 \\
\hline & $\begin{array}{l}\text { Mfa/ } \\
\text { engineering }\end{array}$ & 89 & 3.64 & 0.66 & 0.07 \\
\hline & $\begin{array}{l}\text { Banking/ } \\
\text { finance }\end{array}$ & 126 & 3.46 & 0.68 & 0.06 \\
\hline & Other & 121 & 3.34 & 0.70 & 0.06 \\
\hline & Total & 517 & 3.48 & 0.65 & 0.03 \\
\hline
\end{tabular}

Page 53

(C) 2019 Journal of Asia Entrepreneurship and Sustainability Vol XV, Iss 1, June 2019 RossiSmith Academic Publications, Oxford/London UK, www.publicationsales.com 


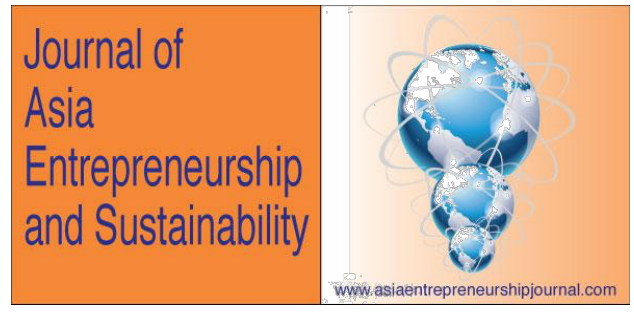

\begin{tabular}{|l|l|l|l|l|l|l|}
\hline & $\begin{array}{l}\text { Overall } \\
\text { Entrepreneurial } \\
\text { Climate }\end{array}$ & $\begin{array}{l}\text { IT \& IT } \\
\text { services }\end{array}$ & 126 & 3.55 & 0.51 & 0.05 \\
\hline & & $\begin{array}{l}\text { Mfg/ } \\
\text { engineering }\end{array}$ & 66 & 3.66 & 0.62 & 0.08 \\
\hline & $\begin{array}{l}\text { Banking/ } \\
\text { finance }\end{array}$ & 90 & 3.50 & 0.64 & 0.07 \\
\hline & Other & 68 & 3.52 & 0.66 & 0.08 \\
\hline & Total & 350 & 3.55 & 0.60 & 0.03 \\
\hline
\end{tabular}

T-statistics show that the difference across different sectors for overall entrepreneurial climate is not significant as $P>0.05$. At the same time in seven out of total 13 parameters the difference is statistically significant $(\mathrm{P}<0.05)$. In seven parameters such as Entrepreneurial leadership, Sponsorship, Encouragement to New ideas, Appropriate awards and reinforcement, Vision \& Strategic intent, Continuous \& Cross-functional learning and Flat organizational structure \& open communication, the mean of sector manufacturing \& engineering is found out to be significantly higher than other sectors. 


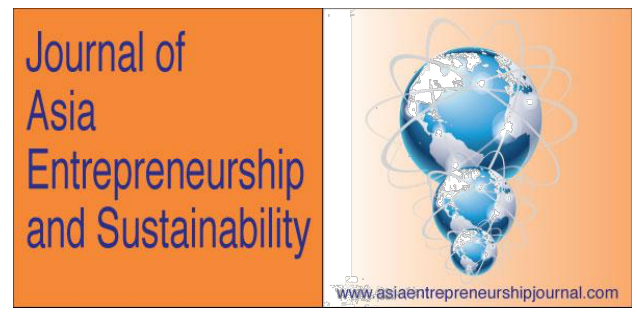

\section{Objective IV: To see the impact of employees' perception related to entrepreneurial climate on their perception related to potential success of the organizations.}

\section{IV.1: To assess the perception of employees related to potential success of their organizations}

Employees' perception related to potential business success is classified into four parameters such as improved financial performance, Strong customer focus, Improved business processes and Focus on people development.

$\mathrm{H}_{07}$ : Employees have neutral perception related to potential success of their organizations.

$\mathrm{H}_{17}$ : Employees do not have neutral perception related to potential success of their organizations.

One Sample T-test is used to validate the hypotheses. Table 8 gives the details of the same. 


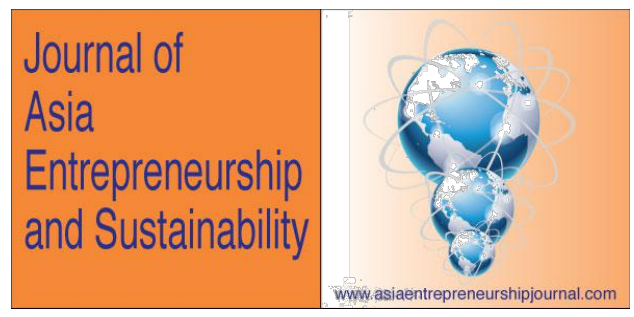

\section{Table 8: One-Sample Statistics of 4 parameters of Employees' Perception} related to Potential Success:

\begin{tabular}{|l|l|l|l|l|l|}
\hline $\begin{array}{l}\text { Sr. } \\
\text { no }\end{array}$ & Parameter & Number & Mean & Std. Dev. & Std. Error \\
\hline 1 & $\begin{array}{l}\text { Improved financial } \\
\text { performance }\end{array}$ & 600 & 3.77 & .76 & .03 \\
\hline 2 & $\begin{array}{l}\text { Strong customer } \\
\text { focus }\end{array}$ & 556 & 3.91 & .69 & .02 \\
\hline 3 & $\begin{array}{l}\text { Improved business } \\
\text { processes }\end{array}$ & 625 & 3.87 & .74 & .02 \\
\hline 4 & $\begin{array}{l}\text { Focus on people } \\
\text { development }\end{array}$ & 610 & 3.73 & .75 & .03 \\
\hline & $\begin{array}{l}\text { Overall perception } \\
\text { related to potential } \\
\text { success }\end{array}$ & 532 & 3.86 & .64 & .02 \\
\hline
\end{tabular}

The T-statistics shows that $\mathrm{P}<0.05$ for all the 4 parameters. Hence it is proved that employees have a positive perception about the potential success of their organizations. The overall mean value of entrepreneurial climate is 3.86 . The 


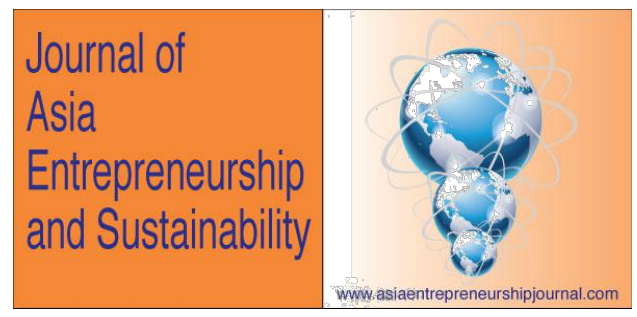

"Strong customer focus" has highest mean value of 3.91. The "Focus on people development" has lowest mean value of 3.73 .

\section{IV.4: Impact of employees' perception related to entrepreneurial climate in} their organization on its perception related to potential business success:

$\mathrm{H}_{08}$ : Employees' perception related to potential success of their organizations is not related to their perception related to entrepreneurial climate. $\mathrm{H}_{18}$ : Employees' perception related to potential success of their organizations is related to their perception related to entrepreneurial climate.

Regression technique is used to validate this hypothesis.

Table 9: Regression analysis of employees' perception related to potential success:

\begin{tabular}{|l|l|r|r|r|}
\hline Sr.No & Independent factors & B & Beta & \multicolumn{1}{l|}{ Sig } \\
\hline & Constant & .556 & & .000 \\
\hline 1 & Entrepreneurial leadership & .009 & .011 & .866 \\
\hline 2 & Management support & .129 & .128 & .030 \\
\hline
\end{tabular}




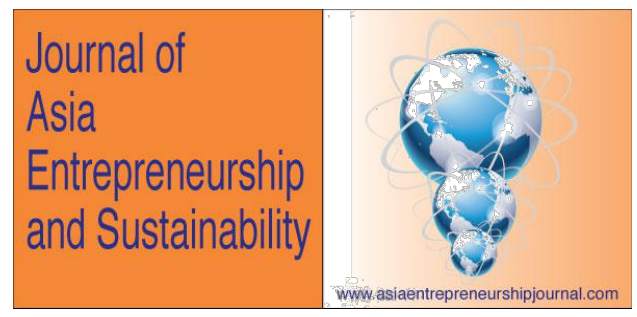

\begin{tabular}{|l|l|c|c|c|}
\hline 3 & Sponsorship (champion) & - & - & .003 \\
\hline 4 & $\begin{array}{l}\text { Tolerance for risk, mistakes and } \\
\text { failure }\end{array}$ & .113 & .175 & .045 \\
\hline 5 & $\begin{array}{l}\text { Encouragement to Innovations \& } \\
\text { New ideas }\end{array}$ & - & - & .581 \\
\hline 6 & $\begin{array}{l}\text { Appropriate awards and } \\
\text { reinforcement }\end{array}$ & .037 & .041 & .002 \\
\hline 7 & Vision \& Strategic intent & .077 & .084 & .136 \\
\hline & Discretionary time \& work & .082 & .092 & .125 \\
\hline & $\begin{array}{l}\text { Empowered / Multi-disciplinary } \\
\text { teamwork }\end{array}$ & - & - & .072 \\
\hline & $\begin{array}{l}\text { Resource availability and } \\
\text { accessibility }\end{array}$ & .079 & .094 & .047 \\
\hline & $\begin{array}{l}\text { Continuous and Cross-functional } \\
\text { learning }\end{array}$ & .006 & .006 & .933 \\
\hline & Strong customer orientation & .399 & .444 & .000 \\
\hline & Flat organizational structure \& & .129 & .015 \\
\hline
\end{tabular}

Page 58

(C) 2019 Journal of Asia Entrepreneurship and Sustainability Vol XV, Iss 1, June 2019 RossiSmith Academic Publications, Oxford/London UK, www.publicationsales.com 


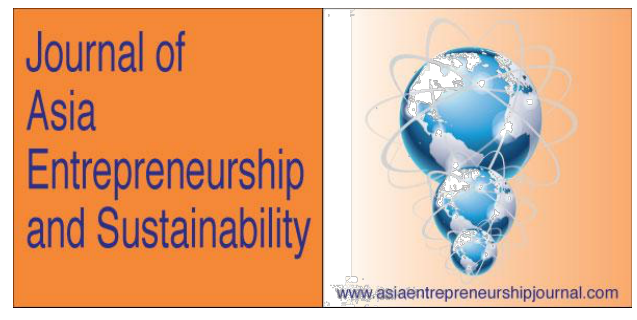

\section{Model Summary}

\begin{tabular}{|r|c|c|c|}
\hline Model & $\mathrm{R}$ & R Square & Adjusted R Square \\
\hline 1 & .792 & .627 & .613 \\
\hline
\end{tabular}

\section{Findings:}

- Employees' perception related to potential success of the organization $=\alpha+\beta 1$ $($ Entrepreneurial leadership $)+\beta 2$ (Management support $)+\beta 3$ (Sponsorship) + $\beta 4$ (Tolerance for risk) $+\beta 5$ (Encouragement to New ideas) $+\beta 6$ (Appropriate awards and reinforcement $)+\beta 7$ (Vision $\&$ Strategic intent $)+\beta 8$ (Discretionary time $\&$ work $)+\beta 9$ (Empowered / Multi-disciplinary teamwork $)+\beta 10$ (Resource availability) $+\beta 11$ (Continuous and Cross-functional learning ) $+\beta 12$ (Strong customer orientation) $+\beta 13$ (Flat organizational structure).

- Out of the 13 independent factors identified to see the impact on employees' perception related to potential success of the organization, six variables such as Management support, Sponsorship, Tolerance for risk, Appropriate awards and reinforcement, Strong customer orientation and Flat organizational structure are found out to be statistically significant as $\mathrm{P}<0.05$. 


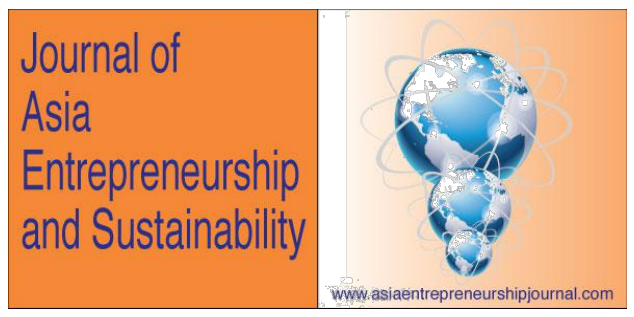

- Employees' perception related potential business success $=0.566+0.129$ (Management support) - 0.145 (Sponsorship) +0.113 (Tolerance for risk) + 0.160 (Appropriate awards and reinforcement) +0.399 (Strong customer orientation $)+0.129$ (Flat organizational structure)

- The adjusted R square value is 0.62 which is significant.

\section{Conclusions:}

The study concludes that out of socio-demographic attributes of the employees the age-group and the seniority in management level have some impact on the employees' perception related to entrepreneurial climate in their organizations. It is found that employees in the age-group of 40 years and above and belonging to middle or higher level of management cadre have significantly higher level of perception related to entrepreneurial climate in their organizations.

The study found that out of organization related attributes, sector of the organization has an impact on the perception of the employees. The employees from manufacturing and engineering sector have a higher perception on some of the parameters of the entrepreneurial climate in their organizations. 


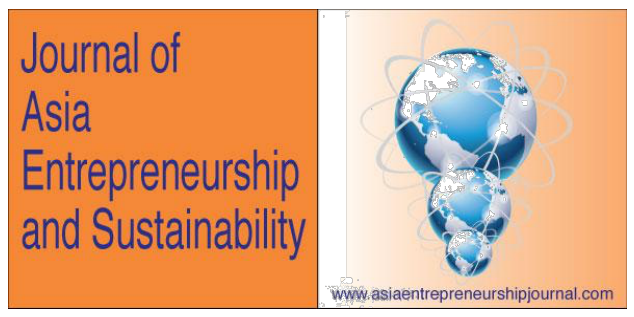

The study also found that there is a positive and significant relationship between employees' perception related to the entrepreneurial climate within their organizations and their perception related to potential success of their organizations. Few important factors which affect their perception are management support, sponsorship, tolerance for risk, appropriate awards and reinforcement, strong customer orientation and flat organizational structure. The regression analysis showed that 'sponsorship' has a negative impact on employees' perception relate to entrepreneurial climate in their organizations. It is possible that there is a limited extent of sponsorship for encouraging innovations in the surveyed Indian organizations. Hence, the employees may have a negative perception about the same.

The existing research clearly mentions the importance of building entrepreneurial culture for the potential business competitiveness. The perception of employees is very crucial in building the entrepreneurial climate and push forward innovations. Our study shows that employees belonging to younger age-group have relatively less assessment of entrepreneurial climate in their organizations. One of the explanations can be that the employees perceive that more autonomy and resources are available only after you reach a certain level of managerial position. It is 


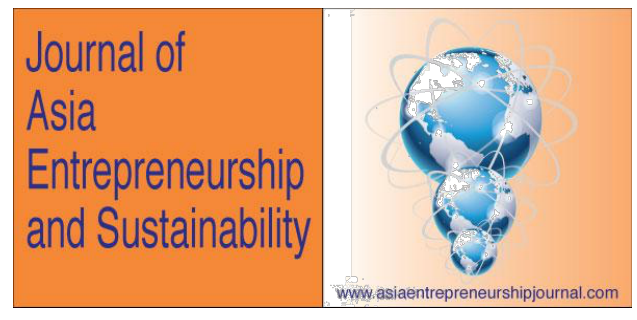

suggested that the organizations should take note of that and engage younger employees in more active manner.

Employees perceive that strong customer orientation followed by sponsorship and tolerance for failures and mistakes are most important for potential success in future. Imbibing those in the organizational culture will require changes in the strategic intent and the policies. The study concluded that though the surveyed employees had a positive perception about entrepreneurial climate in their organizations, it differed across the age-groups, level of managerial cadre and across the sectors. The study also proved that employees' perception related to the entrepreneurial climate within their organizations has a positive impact on their perception related to the potential success of their organizations.

Page 62

(C) 2019 Journal of Asia Entrepreneurship and Sustainability Vol XV, Iss 1, June 2019 RossiSmith Academic Publications, Oxford/London UK, www.publicationsales.com 


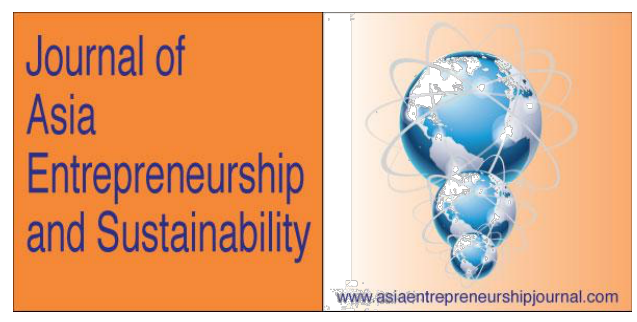

\section{References:}

Chen, J., Zhu, Z., \& Wang, A. (2005). A system model for corporate entrepreneurship. International Journal of Manpower, 26(6), 529-543,604,606 Covin, J. G. and Miles, J. P. (1999) Corporate Entrepreneurship and the pursuit of competitive advantage, Entrepreneurship Theory and Practice.

Ferdousi, S. (2012). Cross-functional teams for corporate entrepreneurship practices. The ISM Journal of International Business, 1(4), 25$1 \mathrm{G}, 2 \mathrm{G}, 3 \mathrm{G}, 4 \mathrm{G}, 5 \mathrm{G}, 6 \mathrm{G}, 7 \mathrm{G}, 8 \mathrm{G}, 9 \mathrm{G}, 10 \mathrm{G}, 11 \mathrm{G}, 12 \mathrm{G}, 13 \mathrm{G}, 14 \mathrm{G}, 15 \mathrm{G}, 16 \mathrm{G}, 17 \mathrm{G}, 18 \mathrm{G}, 19 \mathrm{G}$, 2.

Govender, D. (2010), An Assessment of the Corporate Entrepreneurship in a Petrochemical Company, Mini-dissertation submitted in partial fulfillment of the requirements for the degree Master of Business Administration at the North-West University, Potchefstroom Campus.

Hashimoto, M., \& Nassif, V. J. (2014). Inhibition and Encouragement of Entrepreneurial Behavior: Antecedents Analysis from Managers'

Perspectives. BAR - Brazilian Administration Review, 11(4), 385-406. doi:10.1590/1807-7692bar2014130008

Hayton, J. C., \& Kelley, D. J. (2006). A competency-based framework for promoting corporate entrepreneurship. Human Resource Management, 45(3), 407427.

Holt, D. T., Rutherford, M. W., \& Clohessy, G. R. (2007). Corporate entrepreneurship: An empirical look at individual characteristics, context, and process. Journal of Leadership \& Organizational Studies, 13(4), 40-54.

Hornsby, J. S., Kuratko, D. F., Shepherd, D. A., \& Bott, J. P. (2009). Managers' corporate entrepreneurial actions: examining perception and position. Journal of Business Venturing, 24(3), 236-247.

Ireland, R. D., Covin, J. G., \& Kuratko, D. F. (2009). Conceptualizing Corporate Entrepreneurship Strategy. Entrepreneurship: Theory \& Practice, 33(1), 19-46. doi:10.1111/j.1540-6520.2008.00279.x 


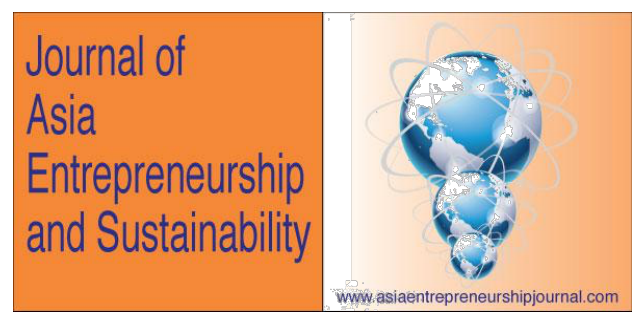

Ireland, R. D., Covin, J. G., \& Kuratko, D. F. (2009). Conceptualizing corporate entrepreneurship strategy. Entrepreneurship: Theory And Practice, (1), 19. Ireland, R. D., Kuratko, D. F., \& Morris, M. H. (2006). A health audit for corporate entrepreneurship: Innovation at all levels: Part II. The Journal of Business Strategy, 27(2), 21-30.

Jenne, T., Rigby, C. and Allum, J. (2016). Stakeolders Engagement in the Creation of an Entrepreneurial Ecosystem, Journal of Asia Entrepreneurship and Sustainability, Vol XII, Issue I, 3-33.

Kang, J. H. (2013). CEOs' transformational leadership and managers' innovative behavior: The investigation of intervening effects in an entrepreneurial context (Order No. 3546447). Available from ABI/INFORM Collection. (1266435922). Retrieved from

https://search.proquest.com/docview/1266435922? accountid $=31551$, dated $6^{\text {th }}$ Oct, 2017

Kotye, B. (2014). Barriers To Small Business Innovation in Rural Australia, Australian Journal of Regional Studies, Vol. 20, No 3, pp 405-428.

Kuratko, D. F., Hornsby, J. S., \& Hayton, J. (2015). Corporate entrepreneurship: The innovative challenge for a new global economic reality. Small Business Economics, 45(2), 245-253.

Kuratko, D. F., Montagno, R. V., \& Hornsby, J. S. (1990). Developing an intrapreneurial assessment instrument for an effective corporate entrepreneurial environment. Strategic Management Journal, 11(4), 49-58.

Lumpkin, G. T. \& Dess, G. G. (1996). Clarifying the entrepreneurial orientation construct and linking it to performance, academy of Management Review, Vol 21, No 1, pp 135-72.

Lumpkin, G. T. and Dess, G. G. (1996) Clarifying the entrepreneurial orientation construct and linking it to performance, Academy of Management Review. Margarietha Johanna, d. V. (2012). Antecedents of strategic corporate entrepreneurship. European Business Review, 24(5), 400-424.

Page 64

(c) 2019 Journal of Asia Entrepreneurship and Sustainability Vol XV, Iss 1, June 2019

RossiSmith Academic Publications, Oxford/London UK, www.publicationsales.com 


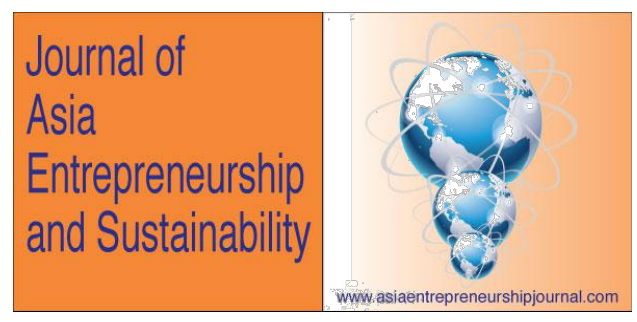

Marvel, M. R., Griffin, A., Hebda, J., \& Vojak, B. (2007). Examining the technical corporate entrepreneurs' motivation: voices from the field. Entrepreneurship Theory \& Practice, 31(5), 753-768. doi: 10.1111/j.1540-6520.2007.00198.x Mazzarol, T. and Reboud, S. (2006) The Strategic decision making of entrepreneurs within small high innovator firms, International Entrepreneurship and Management Journal, Entrepreneurship Theory and Practice.

Melk, M. R. (2010). An Assessment of Corporate Entrepreneurship in the Gold Mining Industry, Mini-dissertation submitted in partial fulfillment of the requirements for the degree Master of Business Administration at the North-West University, Potchefstroom Campus.

Montoro-Sánchez, Á., \& Domingo, R. S. (2011). Human resource management and corporate entrepreneurship. International Journal of Manpower, 32(1), 6-13. Motlhasedi, S.M. (2010), An Assessment of the Corporate Entrepreneurship in the Telecommunications Sector, Mini-dissertation submitted in partial fulfillment of the requirements for the degree Master of Business Administration at the NorthWest University, Potchefstroom Campus.

Petkovska, T. (2015), The Role and Importance of Innovations in business of Small \& Medium Enterprises, Economic developmentDevelopment, No1/2, pp 5574.

Pierce, J. L., and Delbecq, A. L. (1977). Organization Structure, Individual Attitudes and Innovation. Academy Of Management Review, 2(1), 27-37. doi:10.5465/AMR.1977.4409154

Prajoga, D. I., McDermott, M. and McDermott, M. A. (2013), Innovation Orientation and the Effects on Business Performance: Contrasting Small- and Medium- sized Service Firms, $R \& D$ Management, Vol 45, 5, pp 486-500. Preisendoerfer, P., Bitz, A., \& Bezuidenhout, F.,J. (2014). Black entrepreneurship: A case study on entrepreneurial activities and ambitions in a South African township. Journal of Enterprising Communities, 8(3), 162-179.

Ramachandran, K., Devarajan, T.P. \& Ray, S. 2006. Corporate Entrepreneurship: How? The Journal for Decision Makers, 31(1): 85-97.

Page 65

(c) 2019 Journal of Asia Entrepreneurship and Sustainability Vol XV, Iss 1, June 2019 RossiSmith Academic Publications, Oxford/London UK, www.publicationsales.com 


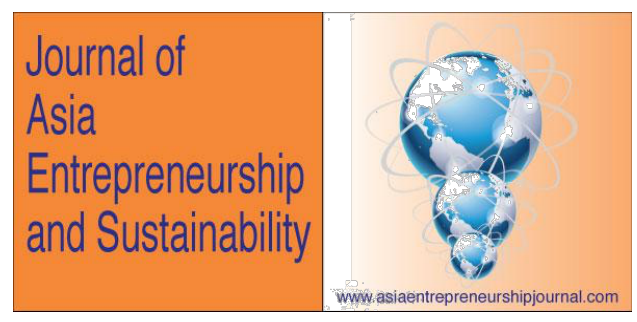

Rutherford, M. W., \& Holt, D. T. (2007). Corporate entrepreneurship. Journal of Organizational Change Management, 20(3), 429-446.

Sebora, T. C., \& Theerapatvong, T. (2010). Corporate entrepreneurship: A test of external and internal influences on managers' idea generation, risk taking, and proactiveness. International Entrepreneurship and Management Journal, 6(3), 331-350

Sharma, P. \& Chrisman, J. (1999) Toward a Reconciliation of the Definitional Issues in the Field of Corporate Entrepreneurship, Entrepreneurship Theory and Practice. , 11-27.

Tutrunc, Ö., and Altuntepe, N. (2015). How Do the Perceived Organizational Support and the Leadership Support Affect Entrepreneurship Behaviours? The Mediating Role of Lmx. Journal Of Alanya Faculty Of Business / Alanya Isletme Fakültesi Dergisi, 7(1), 33-47.

Wiklund, J., and Shepherd, D. A. (2011). Where to from here? EO-asexperimentation, failure, and distribution of outcomes. Entrepreneurship Theory \& Practice, 35(5), 925-946. doi: 10.1111/j.1540-6520.2011.00454.x Zahra, S. A. (1993). A conceptual model of entrepreneurship as firm behavior: A critique and extension. Entrepreneurship Theory and Practice. 17(4), 5-21. Zbierowski, P. (2016). Positive Leadership and Corporate Entrepreneurship: Theoretical Considerations and Research Propositions. Entrepreneurial Business and Economics Review, 4(3), 73-84.

Page 66

(c) 2019 Journal of Asia Entrepreneurship and Sustainability Vol XV, Iss 1, June 2019 RossiSmith Academic Publications, Oxford/London UK, www.publicationsales.com 


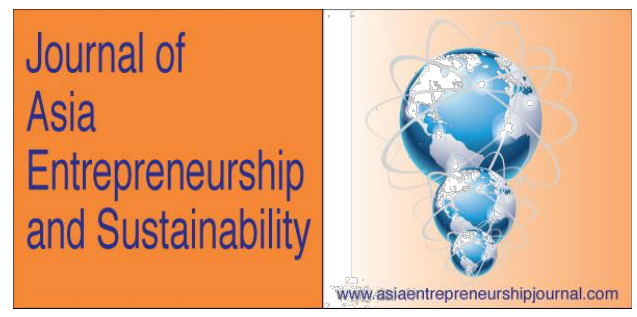

\title{
Seeking for a relevant and contextual approach to economic development, an entrepreneurship model for Africa
}

\author{
L. E. Jowah \\ jowahl@.cput.ac.za; \\ Department of Management and Project Management \\ Faculty of Business and Management Sciences \\ Cape Peninsula University of Technolog \\ Cape Town, South Africa
}

\begin{abstract}
Africa as a continent occupies one fifth of the earth's land surface but possesses the largest natural resources on the earth's surface. The continent is endowed with large deposits of coal, iron ore, asbestos, copper, gold, diamonds, uranium, emeralds, silver, chromium, cobalt, crude oil, quartz, aluminum, zinc, nickel, and platinum, to say the least. Together with this are large fresh water resources that labyrinth the continent pouring their contents into the inland lakes and oceans that surround the continent. The arable land is full of flora and fauna that attracts millions of tourists from around the world who pay large sums to see what the
\end{abstract}

Page 67

(C) 2019 Journal of Asia Entrepreneurship and Sustainability Vol XV, Iss 1, June 2019

RossiSmith Academic Publications, Oxford/London UK, www.publicationsales.com 


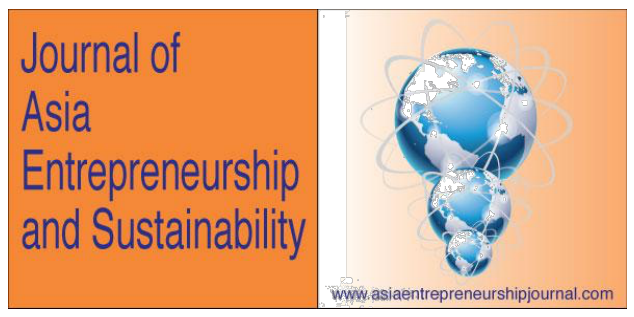

African takes for granted. Yet, the continent is home to millions reeling under chronic poverty, under nourished and under fed with unprecedented high levels of illiterate, unskilled, economically underdeveloped and unbankable populace. The Asian Tigers, China, India and Latin America have emerged as shining stars on the path to sustainable development, but Africa, the storehouse of natural wealth, lingers behind. This paper argues that the failure of Africa is a result of the failure of African leadership to come up with policies and programs specific to the context of the continent. Africa needs sustainable empowerment of the disadvantaged chronically poor millions that languish in poverty on the continent. The model suggests a developmental policy that uses "deliberate structures" to "deliberately empower" the indigenous African as fundamental to the economic development of the continent. Entrepreneurship as a developmental vehicle is modeled to provide in-built-solutions to the 21 causes of the failure of businesses. A model of projectised entrepreneurship using Africanized colonial resources is constructed with special emphasis on South Africa and its unique past. This will be supported deliberately by increasing start-ups at a reduced failure rate in place of perpetual handouts. 


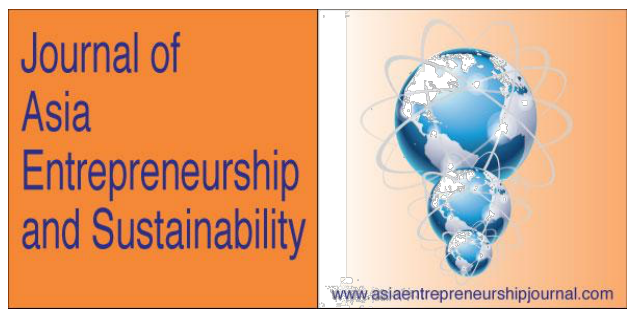

\subsection{Introduction}

Drucker (2007:17) defined entrepreneurship as a mechanism through which economic growth takes place; this mechanism promotes economic growth and development through job creation. Acs, Audretsch, Braunerhjelm and Carlsson (2004.1-40) concur and posit that the main contribution of entrepreneurship is as a knowledge filter that transforms invention into commercially viable products and processes. The is a need to promote entrepreneurship amongst the'unbankable' and disadvantaged of society (Dusiki, 2008:49-60) because that is where chronic poverty is rampant. South Africa is always touted to have one of the world's greatest disparities between rich and poor. The country's historical heritage is evidenced by the presence of millions of these unbankable chronically poor indigenous people. To reverse the effects of apartheid, the planners should start from the premise that $56 \%$ employment creation in any country comes from entrepreneurial start-ups (Olawale and Garwe 2010:729-738). In a separate unrelated study, Bowen and De Clercq (2008:747-767) found a direct relationship between the prosperity of a country, and the levels of entrepreneurial activities in that country. In the United States of America every third citizen is either involved in business or has a relative that is involved in some entrepreneurial activity of sorts, hence the US is an economic powerhouse and the most powerful country in the world today. 


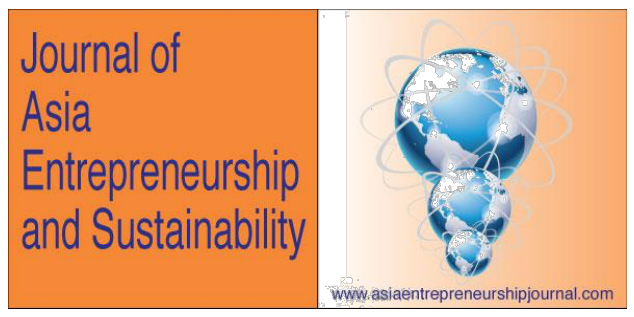

\section{Background to the Study}

Unemployment in South Africa ranges between 25\% and 47\% depending on whose statistics you use. The levels of unemployment are exceedingly too high as evidenced by the levels of poverty and the increase for the need for social grants. The authorities acknowledge that entrepreneurship is the answer (McEnrue, 2011:1-37) to the chronic poverty which is a time bomb waiting to explode. Elsewhere on the continent, South Africa included, governments have opted for privatisation of parastatals as another form of entrepreneurisation of the economies. Sad to say that this method is merely the changing of ownerships and does not bring about new enterprises, thus there is no job creation directly linked to privatization, whatever the reason is given. The African population on the continent continues to grow in a world of unprecedented technological advance and global competition (Aina and Salao 2008:122-125), this simply exacerbates the conditions and need for more pragmatic approaches. It should therefore be logical that sound and context relevant economic policies be put in place to combat the current undesirable state of economic quagmire. Entrepreneurship policies which should relate appropriately to the dynamic globalized environment with deliberate intentions to protect and nurture entrepreneurship amongst indigenous population should be promoted. Africa currently offers nothing apart from raw material in this highly competitive business terrain where ownership of productive means is

Page 70

(C) 2019 Journal of Asia Entrepreneurship and Sustainability Vol XV, Iss 1, June 2019 RossiSmith Academic Publications, Oxford/London UK, www.publicationsales.com 


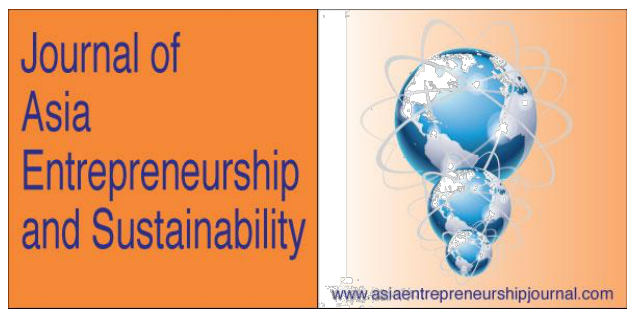

imperative. Yet the continent continues to reel under conditions of extremely low literacy rates with manufacturing and beneficiation as the lowest on the planet (Cilliers, Hughes and Mayer, 2011:1-63).

There is a dire need for well-meaning political will and the creation of a deliberate economic policy targeted specifically for the chronically poor of the society. Improvement of the lives of the millions pre-destined to chronic poverty should be central to any government planning. The current policies on entrepreneurship have no relevance to the realities of the poverty stricken, semi-illiterate and hopeless millions living in the informal settlements scattered throughout South Africa. Using Drucker's (2007:17) definition, entrepreneurship is a mechanism through which economic growth takes place, this should be contextualized to allow for economic growth and development leading to sustainable job creation. The starting point for any effective policy should be an identification of the reasons and factors that make people become entrepreneurs. Migliorini (2006:1-156) cites Cunningham and Lischeron who identified some of the reasons why people get involved in entrepreneurial activities, table 1.1 below highlights the factors and reasons. 


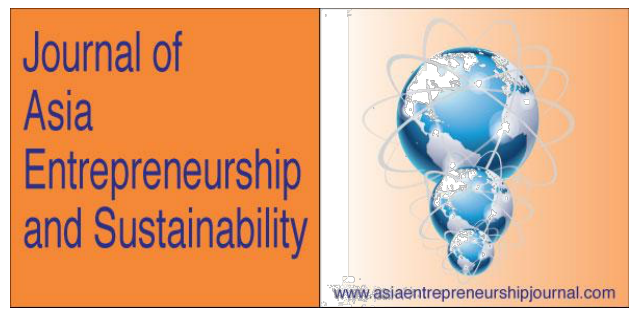

\section{Table 1.1 Reasons why people startup businesses}

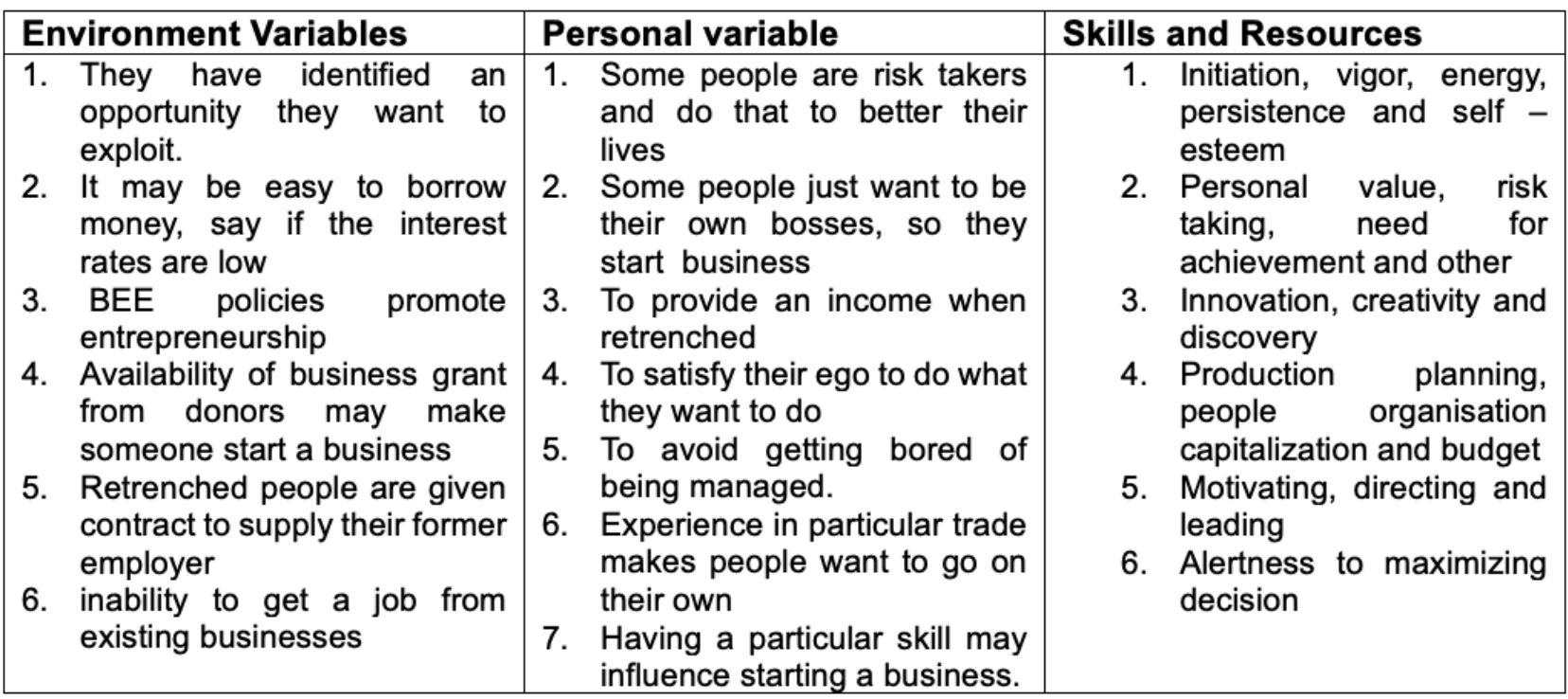

Source: Cunningham and Lischeron as cited by Magliorini, 2006:1 - 156.

It is evident from the above that people start businesses for various reasons, and whatever the reason, any new start-up reduces the levels of unemployment in an economy.

After twenty years of democracy, South Africa still has one of the poorest standards of education on the continent in spite of the country having the financial resources to uplift the standards. The most affected in this are the chronically poor, meaning therefore that they will be poor and disadvantaged perpetually.

Page 72

(c) 2019 Journal of Asia Entrepreneurship and Sustainability Vol XV, Iss 1, June 2019

RossiSmith Academic Publications, Oxford/London UK, www.publicationsales.com 


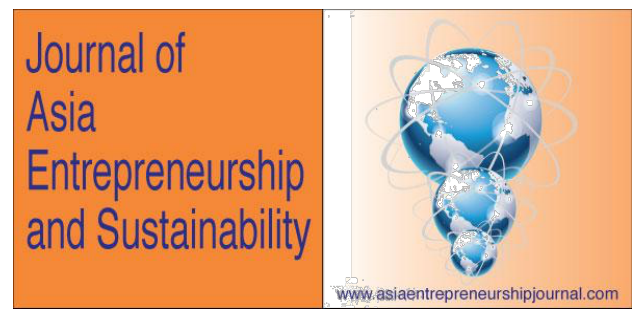

Affirmative action and Black Economic Empowerment have not been successful because there is no feed-stock of educated and appropriately skilled blacks to fill in the necessary gaps. Using statistics discussed earlier, upwards of $56 \%$ of new jobs come from start-ups, and yet $57 \%$ of the South African population does not have matric, this is surely a recipe for disaster. What this means therefore is that blacks will be perpetually poor and may never rise to meaningful positions in the business sector of the economy. Below is a report by Statistics South Africa sixteen years into democracy.

Table 2 Distribution of employment by race in South Africa

\begin{tabular}{|l|l|l|l|l|}
\hline Level of Employment & Blacks & Whites & Males & Females \\
\hline Top management & 13 & 87 & 87 & 13 \\
\hline Senior management & 19 & 81 & 80 & 20 \\
\hline Professionals mid-mgnt & 44 & 56 & 62 & 38 \\
\hline Technical / junior mgnt & 2 & 18 & 60 & 40 \\
\hline Semi-skilled & 82 & 18 & 61 & 39 \\
\hline Unskilled & 98 & 2 & 71 & 29 \\
\hline Casual employee profile & 83 & 17 & 50 & 50 \\
\hline
\end{tabular}

Source: Statistics South Africa 2006

Page 73

(C) 2019 Journal of Asia Entrepreneurship and Sustainability Vol XV, Iss 1, June 2019 RossiSmith Academic Publications, Oxford/London UK, www.publicationsales.com 


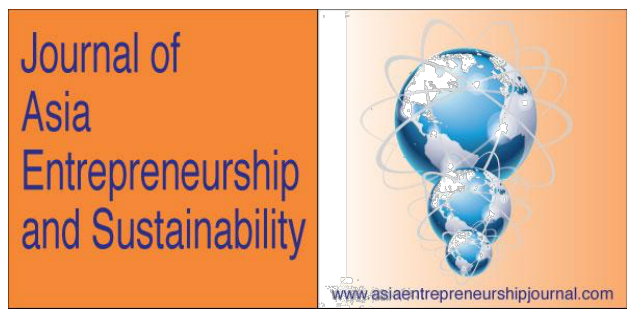

The blame for this dismal performance has always been the "resistance of whites" to change, and this cannot be ruled out. But if the country experiences skills shortages at the levels always indicated, when there is upto $47 \%$ unemployment, it stands to reason that not enough has been done to provide the required skills. It is important to point out also that the $13 \%$ black senior management in the table above is largely government positions which are political appointments. The blacks are the critical mass needed if the country will turn the corner towards economic growth and development with intentions to reduce the chronic poverty.

The role of government in the support for entrepreneurship and by derivation, economic growth and development is seen by the type of policies, legislation and activities as they relate to entrepreneurship (Mok.2005:537-554). South Africa is politically stable with a thriving democracy, and this is critical for the development of an environment where skills can be acquired with little interruption, education can be promoted to the host of the country, and economic growth through entrepreneurship through promulgation of context-relevant legislation (Fatoki, 2011:170-179). The greatest challenge for South Africa is the absence of the feedstock of entrepreneurs given the reasons why people start businesses. The critical skills shortage are the first stumbling block to entrepreneurship since people translate their skills into business ventures. In the absence of such skills, the probability of getting skilled people to start new enterprises is reduced. Whatever 


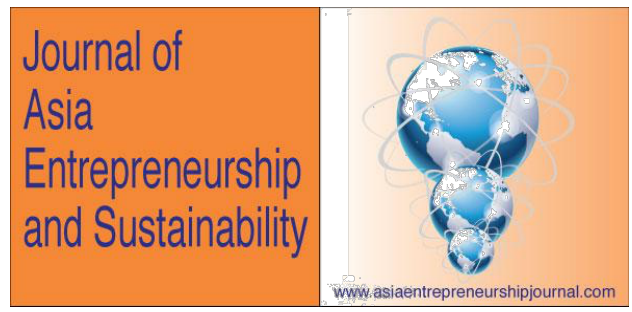

of the few start-ups that will come up will still fall into the traditional 20/80 rule which postulates that $80 \%$ of all business start-ups fail within the first five years of operation. Research has clearly identified the causes of failure of start-ups, it is this knowledge that the author seeks to convert into a model for effective and successful entrepreneurship for the critical mass. Table 3 below lists some of the causes for failure.

\section{Table 3 List of known reasons why businesses fail}

\begin{tabular}{|l|l|}
\hline under capitalisation & lack of skills in the industry \\
\hline poor understanding of business & poor location of business \\
\hline poor strategic planning & lack of management skills \\
\hline wrong type of business & credit sales and cash flow \\
\hline stock shortages & tying down of capital in stock \\
\hline wrong stock & poor control systems \\
\hline wrong pricing & Competition \\
\hline Un-business-like cultural practice & lack of focus \\
\hline lack of hard work & poor customer service \\
\hline unethical behaviour - corruption & poor promotion strategies \\
\hline absence of leadership & no clearly defined objectives \\
\hline
\end{tabular}

Source: Jowah, 2012:

The high failure of business start-ups is a human factor and can be managed as a risk, it is hypothesised that appropriate intervention will reduce the failure rate. The 


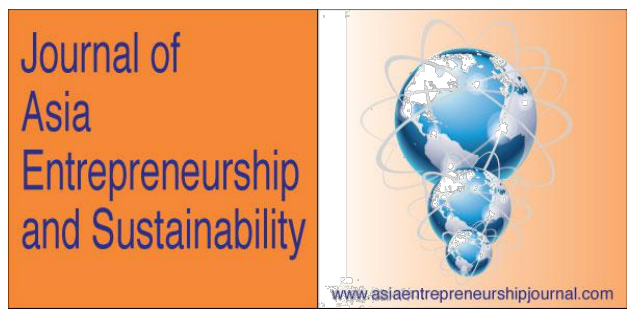

chronically poor cannot access finance for business, and lack of the requisite management skills. They have to comply with complicated tax laws which require specialised human resources (Mahadea, 2008:1-25) which they cannot afford. The small operators buy supplies for cash but sell on 30 days + credits, eroding their cash flow and ability to transact effectively. Consequently they cannot pay salaries, rent, electricity, phone bills, and still purchase raw materials by cash to further finance government and existing big business (Olawale, 2010:1790-1799).

The FICA legislation negatively affects the already thin cash flow of start-ups (Ray, 2010:1-106), and defeats the whole purpose of promoting SMMEs in an economy that does not give appropriate support to emergent entrepreneurs (Rogerson 2004-782). The government is an accomplice in the criminal act of pushing start-ups to bankruptcy because of the FICA system, the 90 day credit system, and the absence of measures to protect indigenous start-ups. Richards (2006:1-117) states that there are no policies, programs and plans that realistically support entrepreneurship. This can be interpreted as clear evidence that the government programs are not deliberately meant to eradicate poverty (Zindiye and Mwangolela, 2007:1-12) but rather to maintain status quo. Whereas entrepreneurship is a "must-have" for economic growth and development, yet the government treats this job creating tool as just another activity the politicians

Page 76

(C) 2019 Journal of Asia Entrepreneurship and Sustainability Vol XV, Iss 1, June 2019 RossiSmith Academic Publications, Oxford/London UK, www.publicationsales.com 


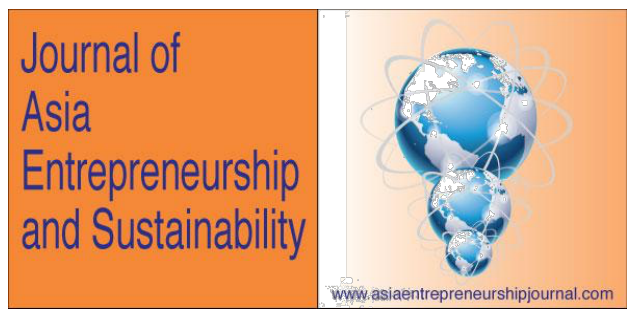

discuss as a matter of fact. This chronic poverty and failure to deliver accompanied by dictatorship have plunged the continent into political unrest (Sholtz, 2009:1125). The unemployment levels are disturbingly very high in a continent with high birth rates (Taylor, 2008:1-125), little relevant education, and continued exploitation of the natural resources by external investors.

\section{Unemployment levels}

There are different types of unemployment (Crane and Crane, 2007:13-25), these may be understood as active job-seekers and the non-job-seeking unemployed who have lost hope and are at home. The non-searching-unemployed individual is not reflected in the statistics of unemployment, but both forms of unemployment reduce the economic well-being of a citizen and lower economic output and erode human capital (Kingdom and Knight, 2002:1-21). South Africa has high levels of both types of unemployment compounded by illiteracy levels amongst the indigenous population (Green, Preston and Sabares, 2010:453-470), even though the country and the continent at large has high mineral and natural resources. The large corporations exploiting the natural resources are exclusively foreign multinationals except for a few nationalised operations. Given the history of blacks that were legally excluded from both quality education and meaningful participation in the economy (Seo, 2010.127-154). Specific skills training and jobs were reserved 


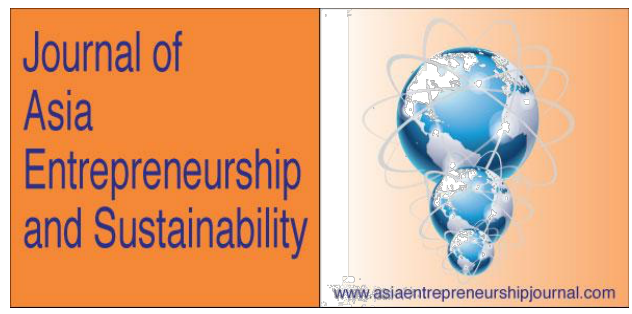

for whites and coloureds to the exclusion of the indigenous people (William, 2010:1-38), and it is these people who are still reeling under the cloud of perpetual poverty. Blacks could not be technicians nor could they register nor operate companies (Lemon and Battersby-lennard, 2010:517-538). Being black meant a special low class education (Bantu Education) designed to make them perpetual servants. The unemployment history of South Africa for the last five years is illustrated in the table 4 below.

Table 4 South Africa unemployment rate 2011 ten years backwards

\begin{tabular}{|c|c|c|c|c|}
\hline Year & Unemployment rate & Rank & $\begin{array}{c}\text { Percent } \\
\text { Change }\end{array}$ & Date of Information \\
\hline 2007 & $25.50 \%$ & 172 & $-4.14 \%$ & 2006 est. \\
\hline 2008 & $24.30 \%$ & 169 & $-4.71 \%$ & 2007 est. \\
\hline 2009 & $22.90 \%$ & 170 & $-5.76 \%$ & 2008 est. \\
\hline 2010 & $24.00 \%$ & 173 & $4.80 \%$ & 2009 est. \\
\hline 2011 & $23.30 \%$ & 170 & $-2.92 \%$ & 2010 est. \\
\hline
\end{tabular}

Source: CIA World Fackbook 2011

These statistics are contested as millions have stopped looking for non-existent jobs (Mahadea and Simson, 2011:1-21), those that no longer look for jobs are not included. Part of the unemployment has been complicated by the influx of

Page 78

(C) 2019 Journal of Asia Entrepreneurship and Sustainability Vol XV, Iss 1, June 2019 RossiSmith Academic Publications, Oxford/London UK, www.publicationsales.com 


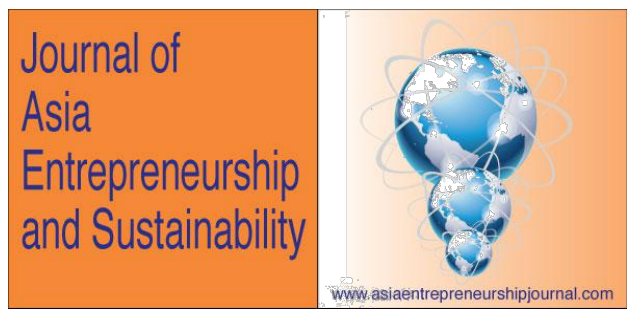

economic-refugees from Africa, Europe and Asia who accept jobs at pathetic salaries (Eweje, 2009:207-223). The highest levels of illiteracy are amongst the indigenous disadvantaged, to this is added every year between $600000-700000$ matriculants entering the job market (Yu, 2012:1-42).

\section{Lessons from other countries; theories and models of economic growth}

In the East Asian models government played direct roles in the formulation of economic policies resulting in the miraculous growths. No generic specific factors have been identified as causative to the miraculous growth, except for; infant industry protection, export-led industrialization, push for universal education, statedirected capitalism, and market oriented centrally planned economies. These policies were complemented by massive education drives and technical skills development on the basis of which development was effected. The centrally planned Chinese and Indian economies brought the much desired economic growth and development resulting in import-substituting-industrialization, protection of the local economy and subsequent development of locally based heavy industries. The autarkic trade policies cut off links between domestic and international markets and instead pushed for exports from protected domestic-entrepreneur policies. Arguably the population sizes created the critical mass necessary for the domestic industries, which was protected from invasion by foreign producers. Six

Page 79

(C) 2019 Journal of Asia Entrepreneurship and Sustainability Vol XV, Iss 1, June 2019 RossiSmith Academic Publications, Oxford/London UK, www.publicationsales.com 


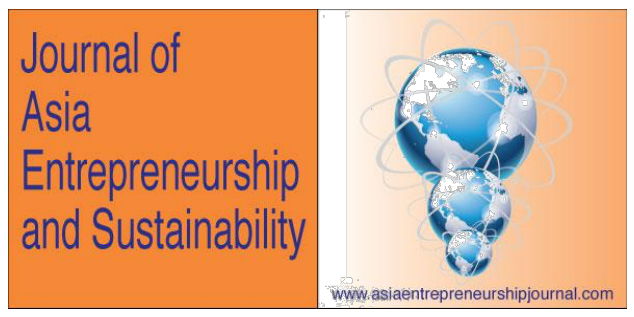

indispensable elements for sustainable economic growth and development can be identified from these countries, these are;

a. stable business environment with low inflation to encourage entrepreneurship and protect infant industries.

b. centralised planning with appropriate sustainable fiscal policies to guarantee equal distribution of benefits from higher growth.

c. exchange rate policies that promote export competitiveness with intentions to have sustainable export programs.

d. context-relevant financial policies that lend to progressive liberalization of the sector and to maximization of domestic savings.

e. implementation of context sensitive pricing policies and provision of clear user-friendly pricing guidelines.

f. contextualised national educational and skills development policies that will improve the human resource capital for the country.

The presence of universal education and skills development was responsible for the presence of competitive skills that helped to buttress the outward looking push for development.

Page 80

(C) 2019 Journal of Asia Entrepreneurship and Sustainability Vol XV, Iss 1, June 2019

RossiSmith Academic Publications, Oxford/London UK, www.publicationsales.com 


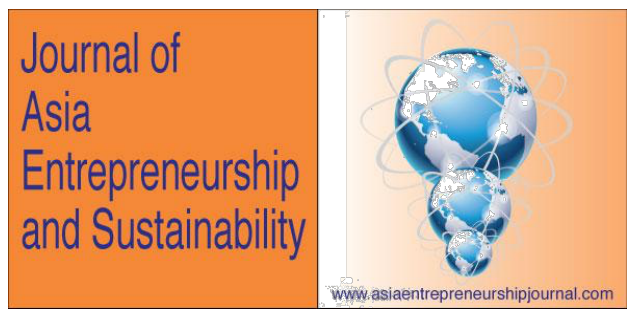

Hong Kong used the four principles of; free flow of information, free movement of people, free efficient flow of funds, and free port with free flow of goods (Hau, 2001:348). The government was directly involved in the activities and facilitated the development of entrepreneurship (Yu 2012:1-18) by creating a conducive environment through 'directive entrepreneurship' through provision of support for start-ups. The government provided; tax incentives, educational reforms, funding, networking and mentoring to encourage and promote new ventures (Tau 2003:425). South Korea combated the rigid labor market by emphasising cooperation between labor, management and government. This made the government the entrepreneur by encouraging investment in sections of the economy, and simultaneously provided financial support to secure the profitability and confidence until stability was attained (Shelton, 2009:1-59). This nurtured and developed capital-intensive industries with contextualised measures to support SMMEs (Jung, 2002:1-16).

\section{Literacy as a measure of prospective entrepreneurship}

Research results indicate that there is a relationship between the level of education in a country and the levels of entrepreneurial activities (Peter and Brijlal, 2011: 265-275), since the highest number of successful start-ups come from those with skills. To eradicate poverty and boost entrepreneurship, Africa has to eradicate 


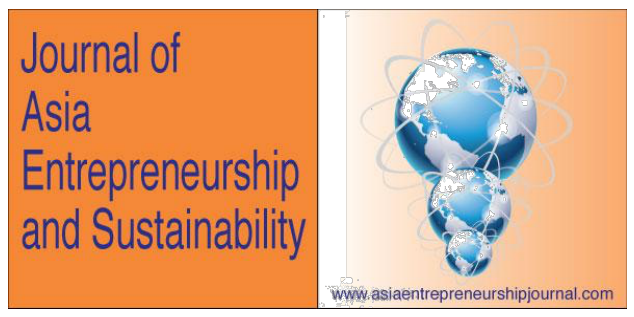

illiteracy by 2020 (Abass, 2010:284) according to the UN millennium goal. Illiteracy hampers entrepreneurship and the absence of entrepreneurship retards economic growth, meaning therefore the the foundations of economic growth reside in the education and skills program put in place by the government. Basing on teacher to pupil ratios, it is clear that education has not been taken seriously by the South African government (Taylor, Dlamin, Kagoro, Jinabhai and De Vires,2010:97-100) and the country may not reach its UN Millennium goals (Isaac, 2007:1-29).

\section{Tertiary education lagging behind in SADC countries}

According to SARUA (Southern African Regional Universities Association) report of June 12, 2012, the SADC region has the world's lowest higher education enrolment and the standards of higher education in the region are deteriorating. The report states; "The quality of higher education in the Southern African Development Community (SADC) region has deteriorated and the number of academic staff has declined. The enrolment rate is $6.3 \%$ with university doctoral registrations at 1\%. In 2010 tertiary enrolment rates of the region were half of what they were in Africa and less than a sixth of the rest of the world'." The report posits that; "In 2050 the region is projected to achieve a $16.3 \%$ higher education enrolment rate - a figure that is too low compared to the current global gross

Page 82

(C) 2019 Journal of Asia Entrepreneurship and Sustainability Vol XV, Iss 1, June 2019 RossiSmith Academic Publications, Oxford/London UK, www.publicationsales.com 


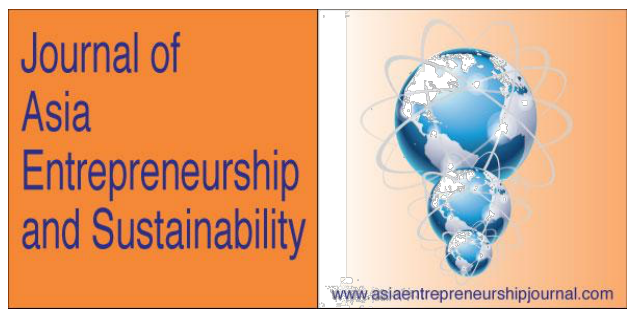

tertiary enrolment rate of $30 \%$. While doctoral education has gained momentum elsewhere in the world. In 2008, SADC produced 1417 doctorate graduates, South Africa alone produced 1274 of these, the remainder of 143 was produced by the other 16 countries (average of 10 doctorates per country). Turkey and Brazil produced 48 and 52 doctorate graduates per million people per year respectively, SADC produced 28 doctorates per million per year. The report admits that the region needs to look at "programme relevance" for the "developmental needs of our region". The "education system must respond to the region's priorities and not 'copy development paths' from developed countries."

SARUA report (5 $5^{\text {th }}$ April 2012) "Building Higher Education Scenarios 2025: A Strategic Agenda for Development in SADC", states; "Because the economic development prospects of the world's countries and regions are increasingly tied to levels of education, the information gleaned from the scenario-building exercise is cause for concern. The most optimistic research predictions about the region's; future development, reduced population growth, higher economic growth - the most significant driver of a better higher education future - and high spending on education, by mid-century the SADC countries are still likely to fall short of the global average participation rate of $30 \%$. All countries that embarked on the path 


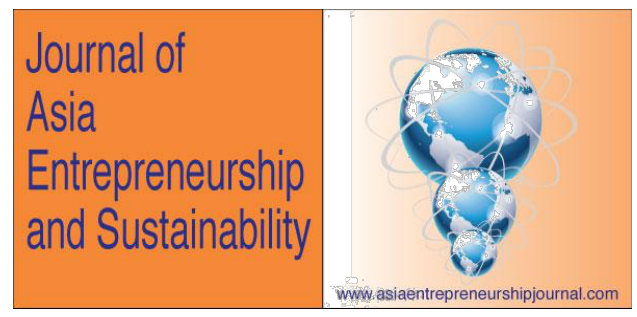

of rapid economic development and growth had reached a 15\% enrolment rate, SADC is at $6.3 \%$, at the current growth rate, the region will reach $16.5 \%$ by 2050 . The university: population ratio in the region is illustrated in the table below.

Table 5 The university to population ratio of SADC countries.

\begin{tabular}{|l|l|l|l|}
\hline COUNTRY & POPULATION & UNIVERSITIES & RATIO \\
\hline Angola & 18000000 & 27 & $1: 666667$ \\
\hline Botswana & 2000000 & 6 & $1: 333333$ \\
\hline DRC & 75000000 & 62 & $1: 1209677$ \\
\hline Lesotho & 2000000 & 2 & $1: 1000000$ \\
\hline Madagascar & 21000000 & 10 & $1: 2100000$ \\
\hline Malawi & 14000000 & 8 & $1: 1750000$ \\
\hline Mauritius & 1.200000 & 6 & $1: 200000$ \\
\hline Mozambique & 23000000 & 21 & $1: 1095238$ \\
\hline Namibia & 2.100000 & 3 & $1: 700000$ \\
\hline Seychelles & .87000 & 2 & $1: 43500$ \\
\hline South Africa & 51000000 & 23 & $1: 2217391$ \\
\hline Swaziland & 1.060000 & 2 & $1: 530000$ \\
\hline Tanzania & 45000000 & 30 & $1: 1500000$ \\
\hline Zambia & 14000000 & 15 & $1: 0.933333$ \\
\hline Zimbabwe & 13000000 & 12 & $1: 1.083333$ \\
\hline
\end{tabular}

Source: Own construction

Page 84

(c) 2019 Journal of Asia Entrepreneurship and Sustainability Vol XV, Iss 1, June 2019 RossiSmith Academic Publications, Oxford/London UK, www.publicationsales.com 


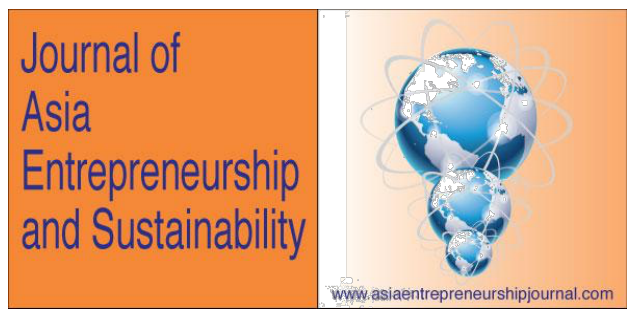

A comparison can be made between the region's university to population ratio with some of the developed and developing countries. Whilst it is possible to bring a measure of development without every one going to school, it is evident that good education results in higher entrepreneurial levels and the subsequent increase in start-ups facilitates both economic growth and development, which in turn reduces poverty through job-creation.

\section{The Proposed South African Model}

The reality on the ground is that South Africa has not done well on the education front, and as such literacy rates and skills are very low amongst the black. Because of the unprecedented history of South Africa, a unique and. deliberate, historicallyrelated socio-economic and culturally relevant entrepreneurial model should be developed. $40 \%$ of the GDP of the country comes from entrepreneurial activities compared to the global average at 70\% (Witbooi, Cupido, and Ukpere, 2011: 19361941). Because entrepreneurship is an indispensable solution for poverty elevation (Olawale and Garwe, 2010: 729-738), the country should identify those key issues that are the pillars for sustainable entrepreneurship.

The first step; The most critical element for grooming entrepreneurs is education, whereas $57 \%$ of the blacks and coloureds who comprise $90 \%$ of the population do 


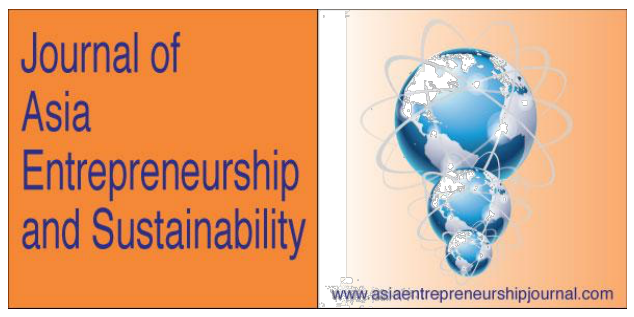

not have Grade 12 level education (Driver, et al, GEM 2001:39). Only 6\% (3 000 000 ) of the entire population (50000 000) has tertiary education in a country that has not built a new university since democratic elections in 1994. The government should re-open and build new teachers' and agriculture colleges to provide high quality teachers to move the country and skills base forward. Mass education with extensive skills training should be part of government development policy. The second step; boosting of technical skills through apprenticeships, technical colleges and technical high schools should be enforced vigorously to turn the tide of the skilless country into a vibrant country with technically literate people. Good governance and the presence of well-developed infrastructure and institutions need to be put in place.

The third step; government policies need relevance to the context in which the community lives, where their perceptions are their realities. The realities on the ground are; they do not have money to start businesses, they do not qualify for business loans, they have no technical skills from which they can sustain themselves, some do have ideas of viable businesses, they are chronically poor and will depend on seeking poor paying jobs and handouts from the government.

Page 86

(c) 2019 Journal of Asia Entrepreneurship and Sustainability Vol XV, Iss 1, June 2019 RossiSmith Academic Publications, Oxford/London UK, www.publicationsales.com 


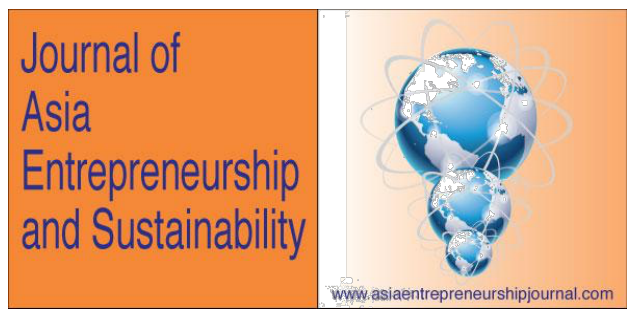

Integration of developmental factors; The generic factor identified as critical for effective economic growth and development is; the direct relationship between human development, economic growth and the consequent economic development (Brux, 2011:231). Hisrish, Peters and Shepherded (2005:10) define economic development as a sustained increase in the standard of living of a country resultant from increase in its human and physical stock. Economic development is measured by evaluating human development (skills and education), Nieman, Hough and Nieuwenhuizen (2003:314) posit that the quantitative measure of human development is evidenced by the literacy rates and economic ratios of a country. It is thereby hypothesised that a proactive developmental state should have deliberate government policies which must speak to the education and skills of its people as a must have and urgently so. The South African black is largely semi-illiterate, no exposure to business or technical skills, no role models to emulate, and no security against which to borrow capital from the bank.

The human capital elements which affect economic growth of a country. are; political stability, conducive government policies, and strategic partnerships. Economic theories postulate a direct relationship between levels of human development and sustainable economic growth. The foundation of economic development is the acquisition of more productive knowledge measured by 


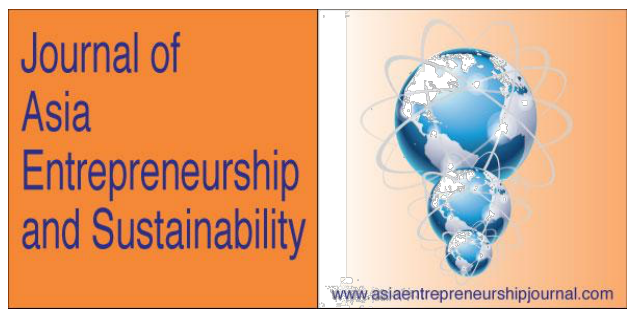

comparison of the GDP against the human development index (HDI). South Africa recently experienced a jobless economic growth, and the "trickle-down effect" theory did not materiaslise as hypothesised by those propagating for macroinvestments and FDI as the answer to economic growth. Evidently, as reported above, economic opportunities, growth and development are best driven by entrepreneurship at the SMME level.

The model; The proposed model seeks to increase the number of entrepreneurshiphopefuls, reduce the start-up failure rate (the magic 20/80 rule), reduce chronic poverty and accelerate the distribution of wealth amongst the indigenous poor. The Global Entrepreneurship Monitor South African Report noted that the formal and public sector failed to absorb the growing number of job seekers (Herrington, Kew and Kew, 2009:1-71). Entrepreneurship was the missing ingredient that would have created new jobs for the economy by supporting SMMEs as effective job creation vehicles (Rwigema \& Venter 2004:315). The role of the government would have been to allow for sustainable local business start-ups protection. Bento (2010:1-58) alleges that SMMEs contribute up to $70 \%$ of job creation in any economy, and it is these that grow to large corporations (Olufunso, 2010:87-98). Any policies on developing and nurturing the SMMEs should be supported by clearly defined enforceable regulations (Dutt and Ros, 2008:386) if the ability of

Page 88

(C) 2019 Journal of Asia Entrepreneurship and Sustainability Vol XV, Iss 1, June 2019 RossiSmith Academic Publications, Oxford/London UK, www.publicationsales.com 


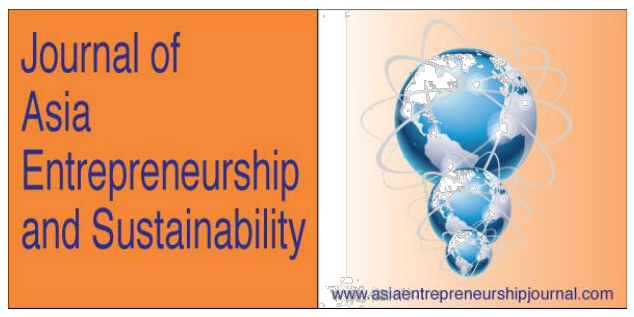

entrepreneurship to organise economies is to be realised and optimized. Entrepreneurship education should be given to play a significant positive influence on the decision by young people to start businesses (Orford, Henrington and Wood, 2004:1-56), and the government must support such initiatives and promote holistic education (Nieuwenhuizen and Kroon, 2002:157-166) at all levels. Special emphasis should be put on the development of entrepreneurship amongst the indigenous people of whom $60 \%$ are chronically poor. What is lacking critically is education amongst these people, let alone the technical skills. which encourage self-employment.

There is relationship between entrepreneurial activities and the level of education, it is thus necessary that education and skills development precede the expectations of a high entrepreneurial attitude. These activities bring qualitative and quantitative changes to the community leading to national competitiveness (Kramer, 2012:186). Since economic development is primarily a policy intervention and whereas economic growth is a phenomenon of market productivity and rise in Gross Domestic Product (GDP), it is necessary for government to promulgate peopleoriented and relevant policies that promote economic growth. It is known that cultural attitude and social background pre-determine the destiny of people (Olufunso (2010:87-97), this sentiment was echoed by Martin Luther King as

Page 89

(c) 2019 Journal of Asia Entrepreneurship and Sustainability Vol XV, Iss 1, June 2019 RossiSmith Academic Publications, Oxford/London UK, www.publicationsales.com 


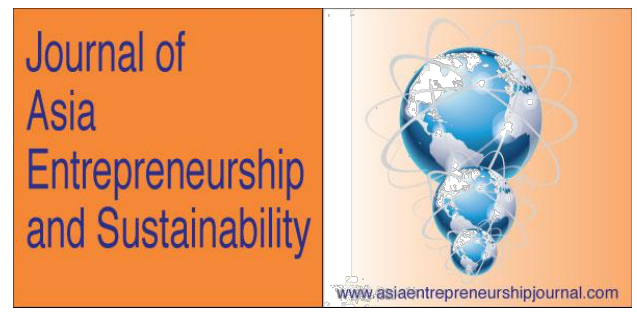

encapsulated in his statement; "your attitude determines your altitude." The right attitude comes as intervention by government by introducing drastic change in education and skills development policies and programmes. Currently the country is under-producing entrepreneurial candidates (Luiz and Mariotti, 2008:1-17) and until the education and skills training is given greater focus, business-start-ups amongst the indigenous will remain extremely low.

There are specific documented causes of business failure, and these causes are listed 8 in table 6 below. It is easy to propose a risk management plan for business start-ups since the causes of failure are known. Identified in the table below can be grouped into three elements, namely; under capitatilsation, lack of management skills and technical skills. In the presence of a people oriented political, these can be supplied to reduce if not eradicate business failure totally.

Page 90

(C) 2019 Journal of Asia Entrepreneurship and Sustainability Vol XV, Iss 1, June 2019 RossiSmith Academic Publications, Oxford/London UK, www.publicationsales.com 


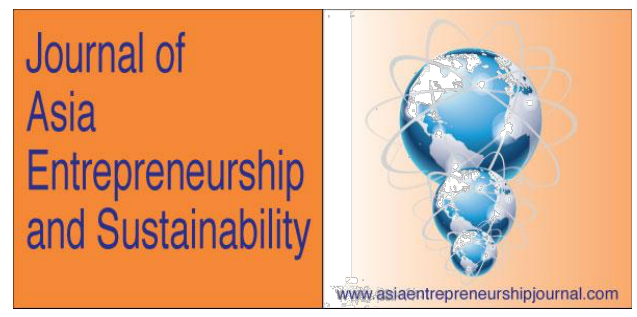

Known causes of business failure

\begin{tabular}{|l|l|}
\hline Under capitalization & Stock shortages \\
\hline Poor understanding & Unnecessarily tying down capital \\
\hline Poor strategic planning & Wrong stock or wrong products \\
\hline Wrong types of businesses & Wrong pricing structure \\
\hline Lack of skills in that industry & Lack of business cultural practices \\
\hline Poor location of the business & Lack of hard work \\
\hline Lack of management skills & Unethical behavior \\
\hline Credit sales create cash flow problems & Poor control systems \\
\hline Lack of focus & Competition \\
\hline Poor Customer Service & Lack of clarity on business objectives \\
\hline
\end{tabular}

Source: Jowah (2011:11)

Under capitalisation; no money, or where available, little money is made available for the start-ups. The under-capitalised start-up struggles to be competitive right from inception, unable to advertise, stock or move into more competitive markets. Sometimes the size of operation is too small from the beginning allowing no adequate returns thus impacting on the Return On Investment and the period.

Lack of management skills; most small business-start-ups have no managerial skills and may have opted to get into business as a survival skill. Business type knowledge, an adequate market survey and appropriate managerial skills will

Page 91

(c) 2019 Journal of Asia Entrepreneurship and Sustainability Vol XV, Iss 1, June 2019 RossiSmith Academic Publications, Oxford/London UK, www.publicationsales.com 


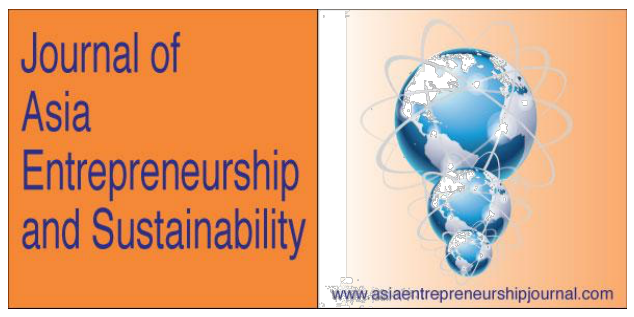

reduce the failure rate of start-ups. A good manager will provide a good strategic plan, avoid wrong types of business, business location, wrong market targeting, and will make appropriate decisions for the business.

Technical expertise; technically literate citizens are more likely to want to start their own operations if the opportunity for funding avails itself. Even where there is an experienced manager, there will be technical aspects of the business that will need specific technical skills. The technical aspects may relate to any aspect of the business, be they accounting, production, and other such operations as would need specialized knowledge.

The factors that cause failure are interdependent and need to be considered as one result emanating from numerous factors. The model is based on the assumption that the few educated and skilled prospective entrepreneurs have essentially three problems; no adequate start-up funds, no management skills and no requisite technical skills. This group of people is technically unbankable, but most of them have ideas convertible to business opportunities. Taking from the list of proposals submitted to the different finance houses, or through a deliberate development programme, the model suggests that: 


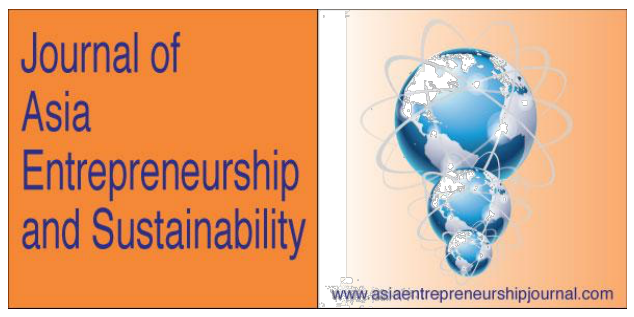

1. economically viable business proposals are selected,

2. the business needs to be large enough to give good returns,

3. the necessary finance is made available for the start-up,

4. the finance must be adequate to employ skilled people,

5. an experienced retired business manager is assigned to the project,

6. the owner of the proposal is seconded to the experienced manager,

7. the owner understudies the experienced manager for the duration of the loan,

8. the owner undergoes extensive training on aspects of his / her business,

9. all the requirements for the operation need to be financed from the loan, 10.all the operations and financing are controlled by the financer, 11.handover a completely functional business to the apprenticed owner.

Page 93

(C) 2019 Journal of Asia Entrepreneurship and Sustainability Vol XV, Iss 1, June 2019 RossiSmith Academic Publications, Oxford/London UK, www.publicationsales.com 


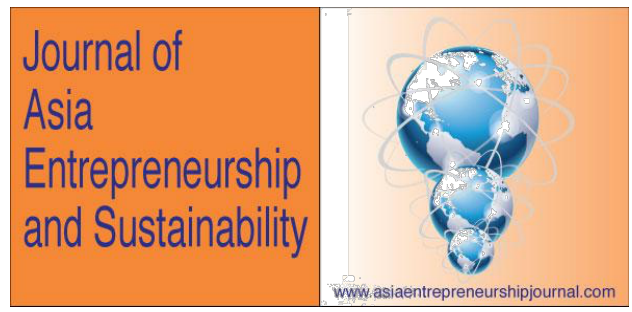

\section{Table 7: Entrepreneurial model for less skilled entrepreneurs}

\begin{tabular}{|c|c|}
\hline Factor & Impact \\
\hline $\begin{array}{l}\text { Establish } \begin{array}{c}\text { a government } \\
\text { finance house providing }\end{array} \\
\text { finance to business }\end{array}$ & $\begin{array}{l}\text { A finance house that doesn't look for credit worthiness but } \\
\text { business feasibility / viability. }\end{array}$ \\
\hline Type of business & $\begin{array}{l}\text { Extensive feasibility studies be carried out once proposals have } \\
\text { been submitted. The start-up should be a viable business and } \\
\text { large enough to sustain itself once it has been established }\end{array}$ \\
\hline Financel & $\begin{array}{l}\text { Adequate finance to meet all operational requirements covering } \\
\text { the period during which the ROI is to be realised should be } \\
\text { provided. Finance should cover the operational costs including } \\
\text { advertising, technical human resources, and room for adjusting } \\
\text { programmes to meet the market changes. }\end{array}$ \\
\hline Managerial competencies & $\begin{array}{l}\text { Experienced retirees will be brought back on contracts for the } \\
\text { duration of the loan payback time. The owner of the business } \\
\text { idea will be given to understudy the experienced manager until } \\
\text { loan payback is complete. }\end{array}$ \\
\hline Competency transference & $\begin{array}{l}\text { Structured extensive mentoring and coaching of the } \\
\text { entrepreneur is embarked on to transfer skills to the apprentice } \\
\text { manager-owner. The business owner will be on salary like the } \\
\text { mentor and coach in charge of the operations. }\end{array}$ \\
\hline Direct link with finance house & $\begin{array}{l}\text { The mentor / coach / manager will report directly to the finance } \\
\text { house. This link allows for intervention where necessary by the } \\
\text { finance house to avoid risks that might crop up. }\end{array}$ \\
\hline Type and size of the project & $\begin{array}{l}\text { The type and size of the project should be such as to sustain the } \\
\text { operational expenses on its own once the production } \\
\text { commences. This means certain sizes (small businesses) may } \\
\text { not be financed through this model. }\end{array}$ \\
\hline Managerial competencies & $\begin{array}{l}\text { Emotional intelligence, leadership styles, soft skills and planning } \\
\text { abilities, knowledge areas, experience }\end{array}$ \\
\hline Environment & $\begin{array}{l}\text { Internal environment; support for entrepreneurs, preparedness } \\
\text { for work, work ethics and remuneration }\end{array}$ \\
\hline Information Gathering: & $\begin{array}{l}\text { Source information from different support institution, coordinate } \\
\text { the information and integrate the communication process. }\end{array}$ \\
\hline Self Confidence & $\begin{array}{l}\text { Belief in one's ability to manage is critical for effective } \\
\text { leadership, it enable assertiveness and strengthens in the face } \\
\text { of economic change }\end{array}$ \\
\hline Conscience & $\begin{array}{l}\text { An entrepreneurs needs to be able to identify pending } \\
\text { problems, understand the feelings of the business environment, } \\
\text { and communicate effectively. }\end{array}$ \\
\hline Influence Skill. & $\begin{array}{l}\text { Influence is the ability to make people support you, work gets } \\
\text { done by people, and the people need to be influenced } \\
\text { positively to be effective. }\end{array}$ \\
\hline Political & $\begin{array}{l}\text { Internal politics; control of resources, coalition, negotiation and } \\
\text { compromises. External; legislation, consumerism, unionism, and } \\
\text { laws governing operations. }\end{array}$ \\
\hline
\end{tabular}

Source: Own construction

Page 94

(c) 2019 Journal of Asia Entrepreneurship and Sustainability Vol XV, Iss 1, June 2019

RossiSmith Academic Publications, Oxford/London UK, www.publicationsales.com 


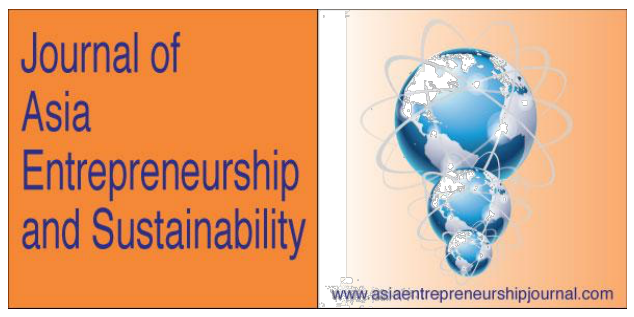

The circumstances under which the indigenous people in South Africa find themselves are extremely pathetic and untenable. Education has not been part of the culture and because they were not allowed to register and run companies in the past, there are high levels of inexperience in business. The low level of education, the absence of role models and the type of education prepares them for a life of servitude. Most go into business with no experience and not willingly, only because they have no job and need to sustain their extended families and themselves. The levels of self-confidence and risk evasion are extremely high. This lowers the morale and increases the fear of failure in the minds of these people without much academic or material reserve for themselves which creates high uncertainty avoidance attitudes.

\section{Conclusion}

In view of the preceding analysis it can be summed up that the greatest need for Africa is a form of a developmental state. This is a form in which the economy is directed by the state with special emphasis on the historical and current condition of the majority of the population. As evidenced by the drastic reduction of poverty in the Asian countries, most of whom had state-led macroeconomic planning, specifically in East Asia. A developmental state has deliberate and visible state intervention sometimes supported by regulation to protect the indigenous 


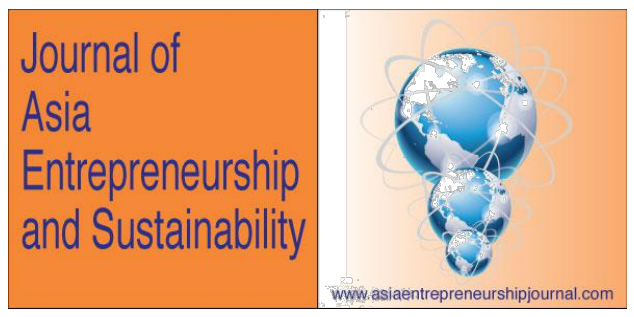

businesses against international predation. Botswana, considered to be a model of poverty eradication on the continent used the developmental state approach to the empowerment of the impoverished population of the desert country. In 2009, the United Nations report indicated that of the poorest 24 countries in the world, 22 of these where in Sub-Saharan Africa. Clearly there is a need to address this situation if the continent is to move out of the current state of economic and social quagmire. For this, a purposeful approach is required in the form of context relevant models. Models should be guidelines and problem solving structures for the entrepreneurial minded citizens adapted to suit the needs of aspirants. The model must be informed by the circumstances surrounding the entrepreneurs and the social structure in which the start-ups take place. Entrepreneurship is the only way of moving Africa from poverty, especially considering that the continent has only $15 \%$ of its population as formerly employed. There is a desperate need to move the continent from producing what they don't consume (mineral resources) and yet do not consume what they produce (importation of finished products) as these products are made from finished goods from exported raw materials from the continent.

With this, it is critical to know that expectations of high levels of entrepreneurship are justifiable only if there is a guarantee to succeed. The government policies that

Page 96

(C) 2019 Journal of Asia Entrepreneurship and Sustainability Vol XV, Iss 1, June 2019

RossiSmith Academic Publications, Oxford/London UK, www.publicationsales.com 


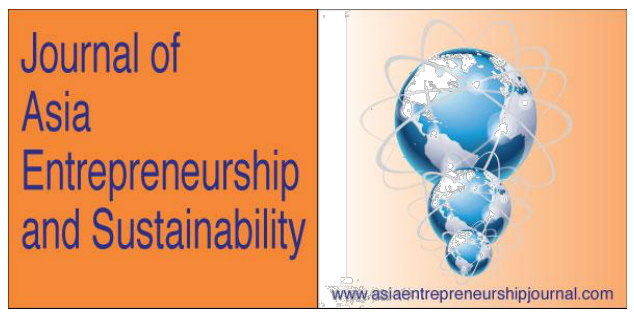

are promulgated have no relevance to the general South African black who is generally considered as unbankable. The citizen has had little education and no work experience with exposure to the operational and supervisory functions of a business. As a community the black populace has very little of "role modelling" from which to learn from except for small street corner kiosks which are purely survivalist operations living from hand to mouth. Too often people employed elsewhere outside of the community have better income than these microoperators. The running of a business therefore remains for the privileged few to the exclusion of the millions that comprise $80 \%$ of the population. When these people are retrenched or when they fail to get a job, then they think of venturing into some income-generating-activity for survival.

The current government programs leave the entrepreneur at the mercy of the banks, though the loan is to be guaranteed by the government agencies. The primary requirement by the banks is to confirm if the individual will be able to pay back the money from their current possessions. These people, historically poor because of where they come from, do not have descent education, 1 out of every 3.4 of them do not afford 3 meals a day. Even where property is available, it is located in the townships and the bank sees no value in that property. If entrepreneurship is what it is said to be, the government has to be entrepreneurial itself and make a bold move

Page 97

(C) 2019 Journal of Asia Entrepreneurship and Sustainability Vol XV, Iss 1, June 2019 RossiSmith Academic Publications, Oxford/London UK, www.publicationsales.com 


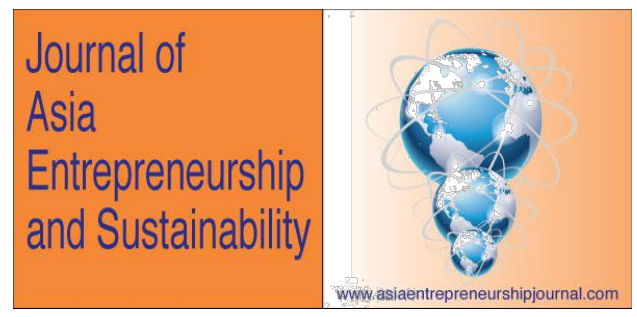

of financing the start-ups directly and not through the banks. Make a deliberate effort to reward those with good and viable ideas with entry level assistance until the entrepreneur is on his / her feet. The model emphasises the importance of viable ideas rather than security for the financing from people who themselves do not own anything. 


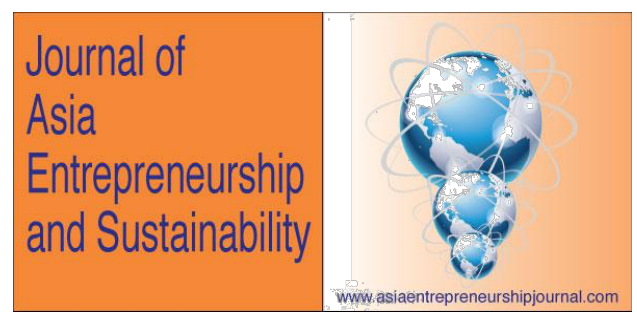

\section{References}

Abass A.2010.Protecting Human Security in Africa. Ed . Oxford University . NewYork

Acss, Z.J., Audretsch, D.B, Braunerhjelm, P. and Carlsson, B., (2004). The missing link: The knowledge filter entrepreneurship in endogenous growth. Central for economic Policy Research, 1-40.

Aina, S.A. and Salao, B.A. (2008). The Role of the three Tiers of Government in Entrepreneurial National Development. Medwell Journals , 2 (4) 122-125

Bento L.V.M., 2010: Welfare Benefits, Taxes and Entrepreneurship: an Economy paradox. Online article.

Bowen, D. and De Clercq, D. (2008). Institutional context and allocation on Bowen, D. and De Clercq, D. (2008). Institutional context and allocation on Entrepreneurial effort. Jornal of International Business Studies.(31):747:76 Brux J.M.2011. Economics Issues \& policy. 5 ed. South -Western CENGAGE Learning. United States of America.

Central Intelligence Agency report 2008.

Cilliers, J., Hughes, B. and Myer,J. (2011) African Futures 2050: the next forty years. Institute for Security Studies.(1) p: 1-63

Crane F.G and Crane E.C., (2007). Dispositional Optimism and Entrepreneurial success. The Psychologist-Manger Journal.(1):p.13-25

river, A, Wood, E, Segal, N and Herrington, M. Global Entrepreneurship Monitor 2001 Executive Report. Graduate School of Business, University of Cape Town Drucker. F . 2007. Innovation and Entrepreneurship. London: Elsevier Linacre House

Dusiki, A.W (2008) Banking for the poor: the role of Islamic banking in microfinance initiative. Journal of Emerald.(24):p 49-60

Eweje G.2009. Labour Relation and Ethical Dilemmas of Extractive MNEs in Niger, South Africa and Zambia 1950-2000. Journal of Business ethic. (2).p;207223 


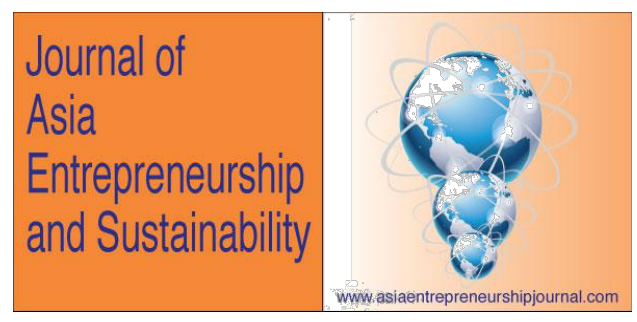

Fatoki O. (2011). The Impact of firm and Entrepreneurial characteristic on access to finance by SMEs in King Williams'Town, South Africa. International Journal of Business and Management.(8).p: 170-179Green A., Preston J. and Sabares R. (2010).Education, Equality and Social Cohesion: A distributional Approach. Taylor and Francis online.

Hau Y., 2001. Entrepreneurship in Hong Kong. http://www.mit.edu/afs.

Herrington, M., Kew, J., \& Kew, P. (2009). Global Entrepreneurship Monitor, South African report. [Online]

Hisrich R.D., Peters M.P and Shepherd D.A. 2005. Entrepreneurship. 6 ed.

McGraw-Hill International. Singapore

Isaacs S.2007. ICT in education in South Africa.

Jung K. 2002. An Upsurge of Entrepreneurship in Korea and its possible Reason.

Kingdom and Knight, 2002. Are Searching and Non-searching Unemployment

Distinct States when Unemployment is High? The Case of South Africa. Journal of European

Kingdom G.G., and Knight J. 2004> Unemployment in South Africa : The Nature of the best. Elsevier. (3) 391-408

LemonA., and Battersby-lennard J. 2010. Overcoming the Apartheid legacy in Cape Town school. Wiley jounal (1). P: 517-538

Luiz J. and Marriotti M. 2008. Entrepreneurship in an Emerging and Cultural Diversity Economy: South Africa Survey Perceptions. South Africa Journal of Economy and Management Science (SAJEMS) (1) 49-65

Mahadea D., and Simson R. 2011. Challenges of Employment creation in South Africa . Conference Paper [7-9 September 2011]. University of Stellenbosch Mahadea, D. and Pillay M.K., 2008. Evironmental condition for SMME development in A South African province. SAJEMS NS 11(4), 431-448. McEnrue, M.P (2011). Government Policies to Enhance Entrepreneurial Activities among Scientific in Kenya.Global Entrepreneurship Conference [6-8; 2011] Washington 


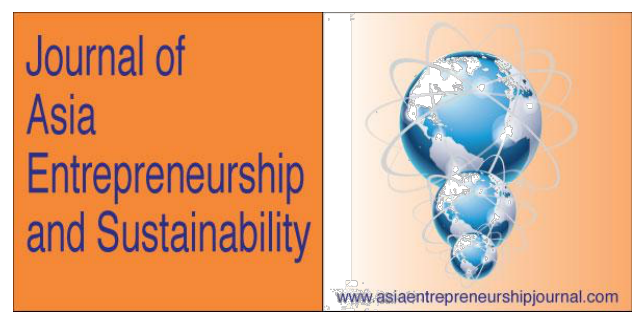

Migliorini, E.B.E.(2006) Entrepreneurship and Women: The making of a business plan for the creation of a distribution business in Danmark. Master Thesis. Aarhus School of Business.

Mok K H. 2005. Fostering entrepreneurship :Changing role of government and higher education government in Hong Kong. Eslevier . available online at www.sciencedirect.com. 537-554

Mok,K.M. (2005) Fostering Entrepreneurship: challenging the role of government and high education governance in Hon Kong. Elsevier (4).p:537-554

Nieman G., Hough J., and Nieuwenizen C. 2003. Entrepreneurship: A South Africa perspective. 3 ed. Van Schaik.Pretoria.

Nieuwenhuizen C, Kroon J (2002). "Identification of Entrepreneurial Success Factors to Determine the Content of Entrepreneurship Subjects", South Africa. International Research Journal (3): 157-166.

Olawale F., Garwe D. 2010.Obstacle to the Growth of SMEs in South Africa principal component analysis approach. Africa Journal of Business Management.

(5) 729-738)

Olufunso, O., F. 2010. Graduate Entrepreneurial Intention in South Africa: Motivation and Obstacle. International Journal of Business and Management. (9) 87-97

Orford,J., Henrington,M. and Wood,E. 2004. General Entrepreneurship Monitor: 2004 South Africa Report

Peter. R.M and Brijlal P. 2011. The relationship between level of education of entrepreneurs and their business success: a case study of the province Kwazulunatal. South Africa. Industry and High Education(4)p:265-275

Ray E, N, 2010. Small Business Entreprise (SME) Finance In South Arica : Implication ofPrivatSector-LEDDevelopment.DelhousieUniversity http://hdl.handle.net/10222/13151 pdf.

Ray, E. N. 2010. Small and Medium Enterprise (SME) Financial in South Africa: Implication for Private Sector-led Development. Dalhouse University. 


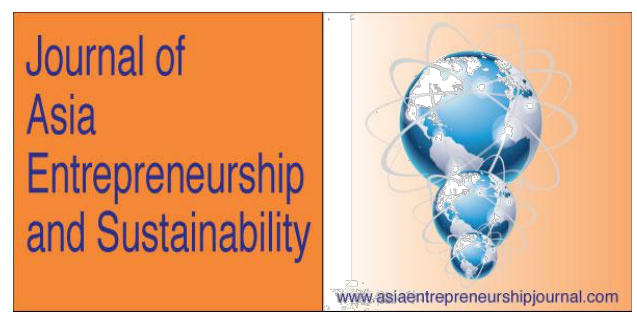

Richards A. D. 2006. Sustainable Micro-entrepreneurship to ensure Positive Economic Growth in the Western Cape. Cape Peninsula University of Technology. Rogerson C.M. 2007. SMME Development in South Africa's Priority Sector. Report for the Department of Trade and Industry. Tshawne: the dti. Rwigema, H. \& Karungu, P. 1999. SMME development in Johannesburg's Southern Metropolitan Local Council: an assessment. Development Southern Africa,. (1), 1-25

Rwigema, H. and Venter, R. (2004), Advanced Entrepreneurship, Oxford University Press, Cape Town.

Seo S. 2010. Macro-Structure for Democratization in South Africa: Racial and Ethinical Cleavages in Apartheid Peiod. SAGE journal (1). P: 127-155 Shelton G. 2009. Korea and South Africa : Building a Strategy Partnership. Institute For Global Dialogue .Occasional paper(61)1-58

Sholtz,L.(2009). A study to determine to what extent companies in South Africa are prepare to use Corporate Social Responsibility as a development tool to alleviate pauverty. Master Thesis . Stellenbosh University.

Statistic South Africa. 2010. Statistic release P0318 General Householders Survey 2010.

Tau, T. M., 2003. Entrepreurial Infrastructure in Singaore: Development a Model and Mapping Participation .Journal of entrepreneurship. (1) 1-32

Taylor M., Dalmin S.B., Kagoro H., Jinabhai., and De Vries. 2009. Understanding High School Students Risk Behaviors to Help Reduce the HIV/AIDS Epidemic in, South Africa. Journal of School Health.(3). P: 97-100

Taylor V.(2008). Social Protection in Africa: An overview of the challenges. Epironline

The Heritage Foundation. 2010 .Gabon Economic Freedom: the link Between Economic and Prosperity. The heritage Foundation \& wall Street Journal ,199200.

William E.2010. South Africa's New Segregation : the Continuation of racial Isolation in Post-Apartheid Era. 


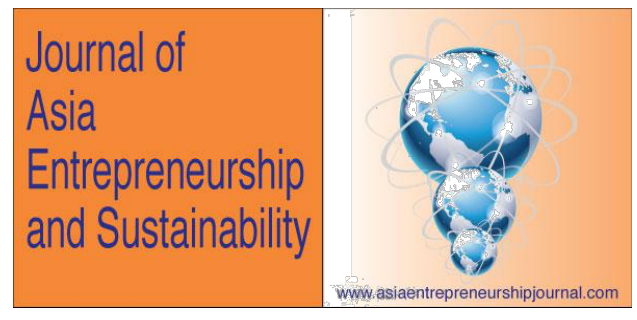

Witbooi M., Cupido C., and Ukpere W. 2011. Success factors of entrepreneurial Activities in the Overberg region of Western Cape in South Africa. Africa Journal of Business Management. (5) 1936-1941

Yu D. 2012. Youth in South Africa labour market since the transition : A study of changes between 1995 and 2011. Department of economics and the bureau for economic research Stellenbosh University.

Zindiye, S., and Mwangolela, T.F., 2007. Entrepreneurship a Key to Poverty Reduction and Socio-Economic Development, 1st International Business Conference. Pretoria, 1-12. 


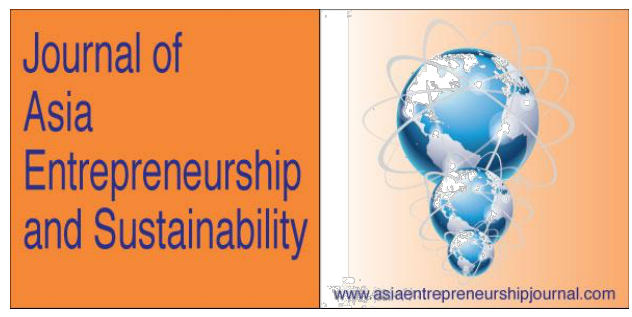

\title{
The role of the international community in preventing conflicts and establishing peace in North Macedonia
}

\author{
Xhyla Çeliku \\ University of Tirana, Albania \\ gjylaceliku@gmail.com
}

\begin{abstract}
This article discusses the role of the international community in preventing conflicts and establishing peace, especially after the Macedonian-Albanian conflict in 2001. This article also reviews the process and aid of North Macedonia's integration into the Euro-Atlantic structures.
\end{abstract}

The strong presence of the United States and European Union has been needed to maintain inter-ethnic cohesion in Macedonia. The presence has also worsened the aggravated political situation in the absence of genuine democracy such as the 


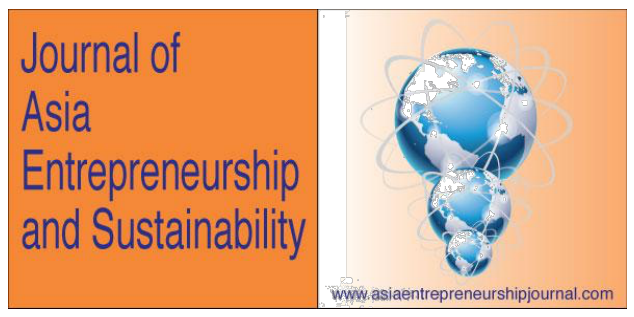

cessation of the Russian and Turkish influences that threatens to turn the country back to the dark past of a perpetual authoritarianism and will guarantee the country a widespread and deserved integration in the great European family to which it belongs.

\section{The social and political arena after the independence of Macedonia in 1991}

With the collapse of Yugoslavia, Macedonia, based on the constitution of 1974, declared its independence in 1991. Although Macedonia physically was separated from the Yugoslav Federation, and avoided war with Serbia, the political mentality didn't change. The first government (run by the Party of Social democrats of Macedonia, LSDM) didn't take into consideration the position of other ethnicities, especially Albanians as they are the largest community in Macedonia. In the Yugoslav Constitution of 1974, article 7, The Socialist Republic of Macedonia belonged to Macedonians, Albanians, Turks and others. It was also a pure multiethnic state. Under the new Constitution of January 17 1992, Preamble, Macedonia belonged exclusively to Macedonians and others, so the new government turned from the multi-ethnic character to a mono-ethnic state. This caused much disaffection among the Albanian community in the new state of Macedonia. It was evident that the new state will have internal problems too; the external ones were present since 1945, when Tito created the Republic of Macedonia "to prevent the 


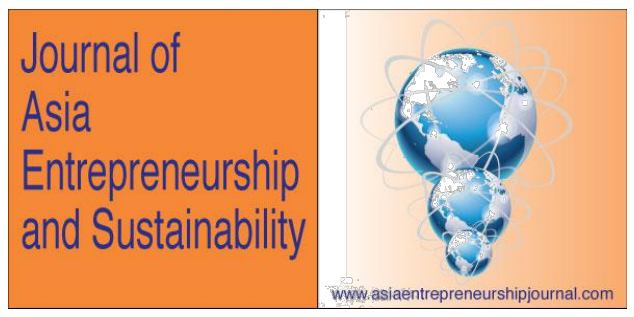

Serbian and Bulgarian influence in Yugoslavia" (see Wheithmann 2000:230), but also to marginalize the autochthonous Albanian population in Macedonia, in order not to dominate this territory.

The new state of Macedonia faced many external and internal problems. The first external problem came from Greece which didn't recognize the constitutional name of the country. Greece referred to Macedonia as Former Yugoslav Republic of Macedonia (FYROM) and this caused not only political problems, but also economical ones because of the embargo Greece put on Macedonia. Additionally, Bulgaria had territorially aspirations for the region of Macedonia and didn't recognize the Macedonian language. Till today, Serbia does not recognize the autonomy of the Autocephaly Macedonian Orthodox Church.

The first internal problem came in 1992, when the Albanians were unhappy with their secondary status in the new state of Macedonia. Albanians living in Macedonia had no rights to education, the use of Albanian language and Albanian symbols and were not represented in the state administration, came to the idea of organizing a referendum to achieve political and territorial autonomy within Macedonia. Although the Albanian population voted $97 \%$ for and declared the Republic of Ilirida, a federal model within the Republic of Macedonia for resolving 


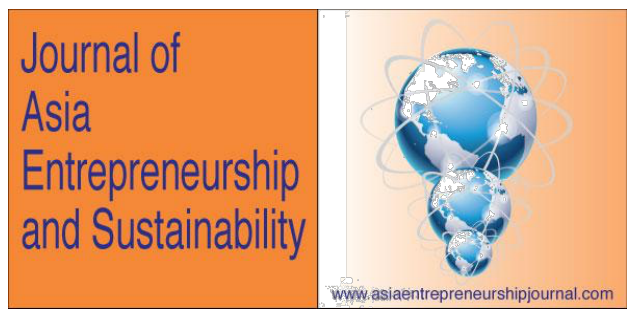

the Albanian question, the referendum failed because of the influence of still strong ex-Yugoslav intelligence structures in the first Albanian political party in pluralism PPD (The Party for Democratic Prosperity). PPD was successful in dividing leadership and promoting the idea that Albanians can only achieve national rights within the system (for more see the Interview of Mersin Pollozhani, deputy of PPD, daily newspaper "Ina-Online”, 08.04.2017).

The second internal problem happened in 1994, when a group of Albanian intellectuals, who mainly studied at the University of Prishtina (Kosovo), came to the initiative to establish an Albanian university in the city of Tetova, WestMacedonia. Even the intervention of police forces over the Albanian population that ran to the streets to protect the University and during this conflict, a young Albanian man was killed. The regime couldn't shut down the University, but the University of Tetova wasn't recognized by the State of Macedonia until 2004.

The third problem happened in 1997, when the Mayor of the city Gostivar, Rufi Osmani raised the Albanian flag in sign of protest for prohibition of Albanian symbols by the state. The police forces were ordered to intervene and similar to the incident in Tetovo, one young Albanian man was killed along with hundreds of protestors arrested. 


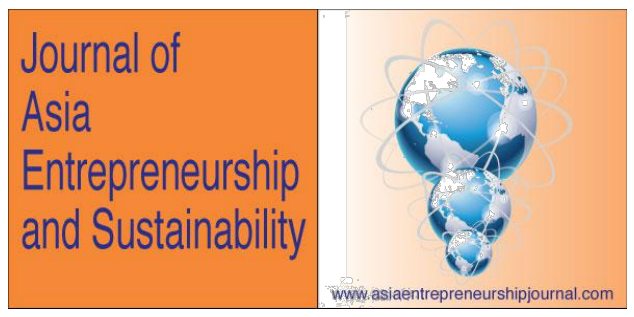

After these inhumane incidents, a continuous state repression against Albanians in ex-Yugoslavia and in the new state of Macedonia, Albanians continued to fight for national legitimate rights. The fourth largest issue faced Macedonia in its young history as a state: the armed conflict in 2001. Through international mediation, war was avoided. All parties came to a compromise, called the Ohrid Framework Agreement, which ended the conflict and created a platform for inter-ethnic dialogue in Macedonia.

The last problem Macedonia faced was in 2015-2017, called the political crisis in Macedonia, which threatened again the inter-ethnic cohesion and the whole economic, political and social system of the country.

\section{The role of the international community in inter-ethnic balance in}

\section{Macedonia}

Right after the independence in 1991 and in the beginning of political pluralism, the first president Kiro Gligorov tried to represent Macedonia as an "oasis of peace", a kind of propaganda in international opinion: that all ethnicities live together and in peace. But, as discussed before, you cannot create an oasis of peace, a real multi-ethnic state and declaring a pure mono-ethnic constitution:

\section{Page 108}

(c) 2019 Journal of Asia Entrepreneurship and Sustainability Vol XV, Iss 1, June 2019 RossiSmith Academic Publications, Oxford/London UK, www.publicationsales.com 


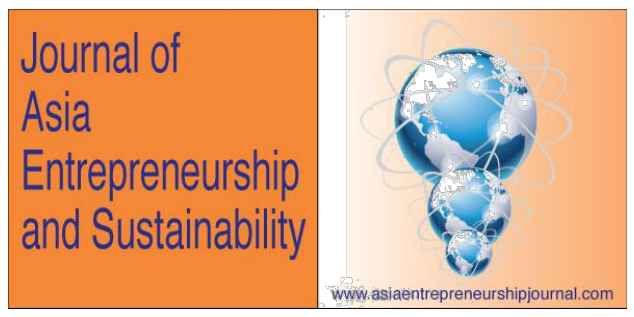

"Macedonia belongs to the Macedonians and the others ..." (Macedonian Constitution, Preamble, 17 January 1992).

The on-going internal problems discussed above like the Declaration of Republic of Ilirida (1992), the foundation of the Albanian University in Tetova (1994) and the raise of the Albanian flag in Gostivar (1997) were on the focus of the international community, but still not a real reason to act. The international community was still passive observer in the inter-ethnic confrontation in Macedonia until the conflict in 2001.

The armed conflict in 2001 between Macedonians and Albanians was the right time and reason to act. The international community knew that the conflict could spread throughout the Balkan region and the Macedonia couldn't exist anymore. The Ohrid Framework Agreement was directly mediated through the State Department and European Union and it was meant as a compromise agreement for achieving peace and keeping an inter-ethnic balance in Macedonia.

For a decade and a half, the impression was created that the overall social-political situation in Macedonia consisted of problems of ethnic character. Even the discourse that had consistently imposed on both Macedonian and Albanian political parties had created a local and international image that the socio-political 


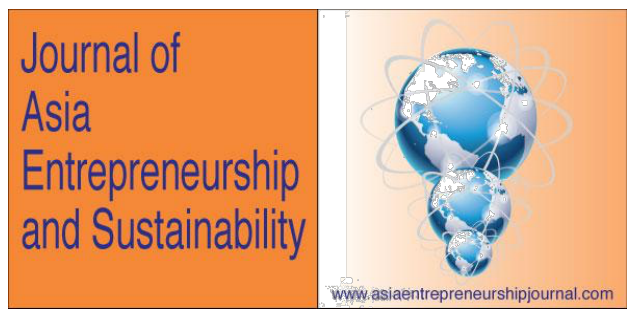

crisis in Macedonia was largely ethnic. On the other hand, both the ruling parties: VMRO-DPMNE in the Macedonian bloc and the DUI in the Albanian bloc promoted their integration into Euro-Atlantic structures; meanwhile they also continued to have international support.

VMRO led by Gruevski in 2006, promoted economic reform and Euro-Atlantic integration in front of the electoral body, managed to take its political rival, the Social Democratic Union of Macedonia (SDSM), into opposition. However, since 2008 , convincingly winning the then-early elections, after entering into a coalition with Ali Ahmeti's DUI, Gruevski and his party changed the political course and established a nationalist-autocratic agenda. They created a general image that the governing partner, DUI, were in constant enmity, not in co-governance.

This type of policy-making, whether intentional or not, created a marked interethnic polarization: on one hand Macedonians feared that after the compromise of the 2001 conflict, the Albanians would slowly take over the state, and felt secure under the national plan under the VMRO. On the other hand, this policy-making fuelled the bloodshed of the Albanian population, who was convinced that Gruevski and his party turned the state of affairs before the 2001 conflict. DUI began to assume a neutral role, which was the first time in history and was causing a revolt of Albanian voters and public opinion. 


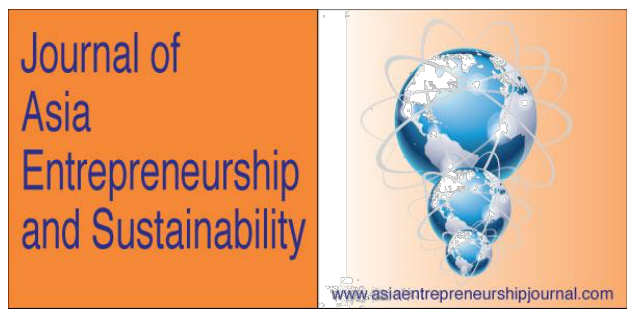

Due to this discourse characterized by hate speech and the persecution of political opponents by Gruevski and his party, it led to a series of parliamentary boycotts between 2007-2015. This situation was not well received either by the international community, the EU and the US who, since 2001, through the Ohrid Framework Agreement had invested so much energy and resources in creating interethnic confidence and in maintaining stability and peace. Therefore, since 2014, the annual progress of the European Commission for Macedonia as a country has opened accession negotiations since 2005 has been consistently negative (see European Commission, 2016a).

The international community, being aware of the danger of this populist-nationalist politicization, which could quickly lead to the imbalance of inter-ethnic relations in the country, so fragile, tried to mediate an agreement between the position and the opposition: "The EU was determined to fill the gap that political actors in Macedonia created in the political process" (Markovikj and Damjanovski 2015: 21). As a consequence, the EU turned into an active actor in creating a political balance in Macedonia, which Kacarska (2015:112) characterizes with the epithet of 'arbiters', promoting the normal functioning of the socio-political process in the country. 


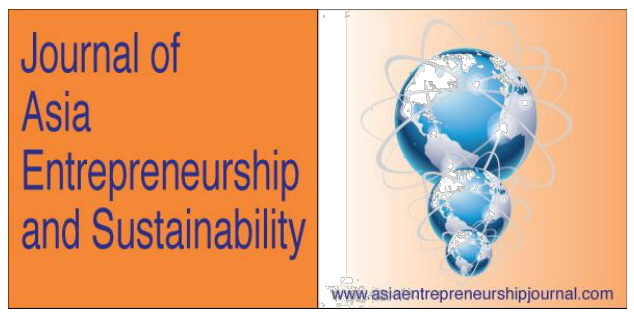

In particular, the notorious Skopje 2014 project revealed a lot of truths about the fact that patriotic discourse had been just a farce. Through this project, which cost less than 700 million euros from the state budget, Gruevski and his clique had managed to cash in large sums of money and VMRO-DPMNE had probably become the richest party in Europe. Since the project consisted mostly of statues, mainly in the center of Skopje, and the construction of these statues is counted as artwork, so their cost is inexcusable, and the contracts that had been signed with Italian artists in Florence amounted to over 1 million euros per statue. The opposition and public opinion were aware of this manipulative tract and began to vex the blood from 2012 to 2015, when Zaev, the Macedonian opposition leader, began to plummet the so-called political 'bombs'.

\section{The beginning of the political crisis and the effort of the international community in restoring political normality}

In January 2015, when current Prime Minister Zoran Zaev and SDSM leader signalled he had a huge secretive archive containing controversial information about Nikola Gruevski's regime, a major political crisis broke out in Macedonia, which could have major consequences for the country. Political Bombs, as they called Zaev, were recorded illegally by the secret service over a period of more than 4 years and included conversations of more than 20,000 people, including 


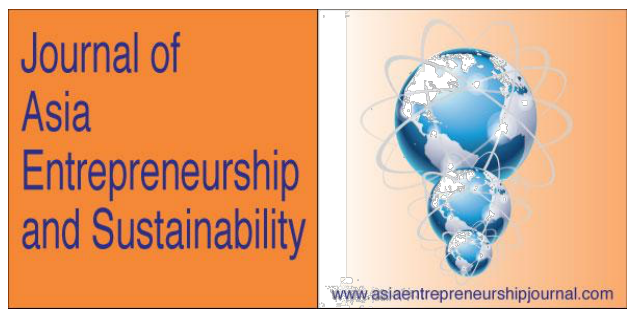

journalists, opposition figures, ambassadors, and some of government ministers. In a word, political bombings exposed a great deal of systematic abuse of power by invoking electoral manipulations, corrupt affairs, revenge against political opponents in various forms, mounted political prisoner cases, and the intent to cause inter-ethnic tensions through the case Monstra, for which innocent Albanians still suffer imprisonment.

The European Commission, faced with this difficult political situation in Macedonia, ran to work, seriously addressing the problem. Thus, the Commission's political experts developed a two-way approach to addressing the political crisis: the first was called 'systemic methods', which included the spectrum of experts, and the second 'mediating method', which included the political spectrum (see Fonck 2018:1312).

The expert group, led by Commission Retired Director, Reinhard Pribe, was tasked with carrying out a profound crisis analysis and offering a set of valuable recommendations to overcome the situation. Later, the work of the expert group was summarized in the phrase 'Urgent reform priorities' (see European Commission, 2015). 


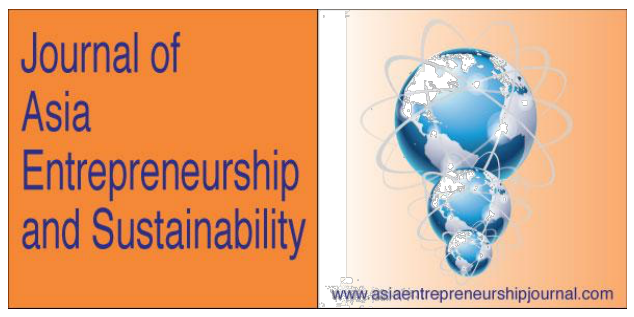

Working in parallel, the political group focused on finding a solution through mediating talks between the position and the Macedonian opposition. Thus, Commissioner Johannes Hahn on February 17, 2015 paid an official visit to Skopje and proclaimed the European Commission-supported dialogue among the four largest parties in Macedonia: VMRO-DPMNE, SDSM, DUI and DPA. However, Hahn, without widespread consultation with EU bodies and with the assumption that the situation was not so critical, failed to get things right. Macedonian controversial President Gjorgje Ivanov called a meeting of leaders for dialogue, but was rejected by opposition party leaders.

\section{Initiation of a viable international mediation agreement to overcome the political crisis}

The political scandal in Macedonia was so large that fears emerged again after 2001 that serious stability and peace could be seriously hurt in Macedonia, which was achieved with much international effort and commitment. Thus, the EU proposed to lead talks on the exit from the political crisis, however, also seeking US assistance in this complex political process (see Fonck 2018:1313).

Thus, three different rounds of talks were organized. The first two rounds of talks (March 30 and April 15, 2015), both held in Brussels, developed separately with representatives of VMRO-DPMNE and SDSM and mostly served to identify the 


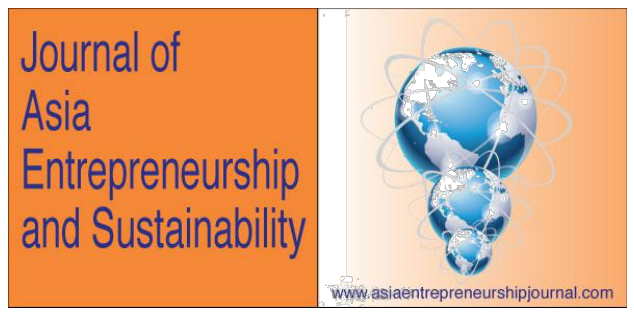

requirements, the differences and the sensitive issue of both sides. The third round of talks was held in Strasbourg on May 19 and was more crucial in terms of two issues. First, the talks passed on to an inalienable stage for both sides and the opposition's request for the formation of a transitional government was updated. Second, for the first time, Gruevski and Zaev agreed that the talks would be held in the presence of both, not separately.

Thus, in the process of tripartite talks: the European Parliament (as a supervisor), the Commission and the Macedonian actors, Parliament was asked to participate more actively, as Commissioner Hahn, who played the role of a neutral party, did not enjoy enough faith of SDSM (see Fonck, Ibid, p. 1313). The direct involvement of the European Parliament was a counter-argument that Commissioner Hahn did not defend or support VMRO-DPMNE. Therefore, and to intensify the talks and reach a faster resolution, the European Commission invited the representatives of the European Parliament, namely the left and the right, to participate, where SDSM is linked to the Socialist Party (PES), while VMRO-DPMNE is a member of the European People's Party (EPP), with the aim that the representatives of these two political groups have influence over the two protagonists of the crisis, Gruevski and Zaev. Thus, a negotiating team was created: Richard Howitt of Great Britain and member of the S \& D Socialist Group, Eduard Kukan from Slovakia and a 


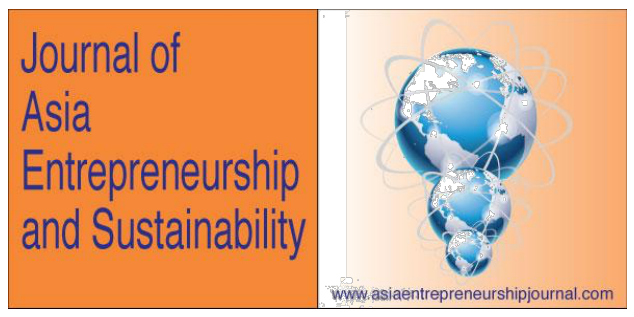

member of the conservative EPP group, and Ivo Vajgl from Slovenia and a member of the liberal group ALDE in the role of impartial in this complex process of negotiation.

The involvement of the Commission, the European Parliament directly and the tripartite troupe team in the process of talks to emerge from the crisis, outlined the appropriate political lines that an agreement would soon be reached between the parties to the VMRO-DPMNE conflict on the one hand, and SDSM on the other.

\section{Arranging the Political Agreement (May-July 2015)}

After the third round of talks organized by the European Parliament on May 19, the Commission took over the leadership and put the parties in conflict at great pressure, especially after the outbreak of all-round protests across the streets of Skopje and in the case of Kumanovo, where nine police officers and 18 members of the so-called Kumanovo Group were killed.

Considering that the situation in Macedonia was too critical, talks were held almost every day in Skopje, led by an engaged mediator of the EU delegation to Skopje (conversation with French Ambassador in Skopje, Mr. Timonie, 15 September 2017). After a few weeks, the so-called Conciliation Agreements were reached, 


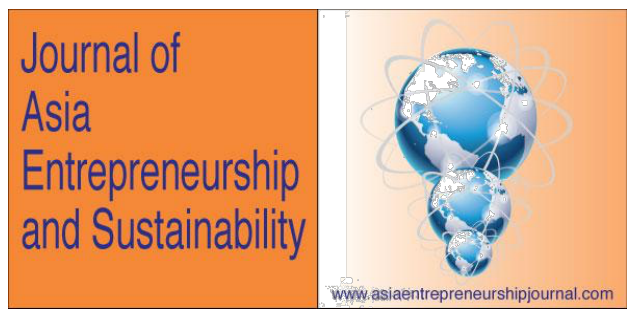

according to a suburban neighbourhood in eastern Skopje, where leaders' meetings were organized in the presence of international representatives, namely June 2 and July 15 . The signing of the final agreement was signed by four leaders of the largest parties (VMRO-DPMNE, SDSM, DUI and DPA) at the residence of the EU Ambassador in Skopje, in the presence of Commissioner Hahn and EU Ambassadors and Ambassador USA in Skopje.

By signing the agreement, four major party leaders agreed that SDSM would stop boycotting and return to parliament, forming a parliamentary commission tasked with investigating an illegal interception scandal, forming a transitional government, to reform the Central Election Commission (CEC), to clean up the manipulated election list, and to lay down the resignation of Prime Minister Nikola Gruevski 100 days before the parliamentary elections scheduled for April 2016. The most important point reached in the deal was the formation of the Special Public Prosecution, which would have full autonomy in the investigation of illegal wiretapping (see June 2015 Agreement; July 2015 Agreement).

Although at first glance it seemed that the role of the European Parliament actors was insignificant in reaching an agreement in Macedonia because the ambassadors of the EU countries and the US ambassador in the country had the task of reducing 


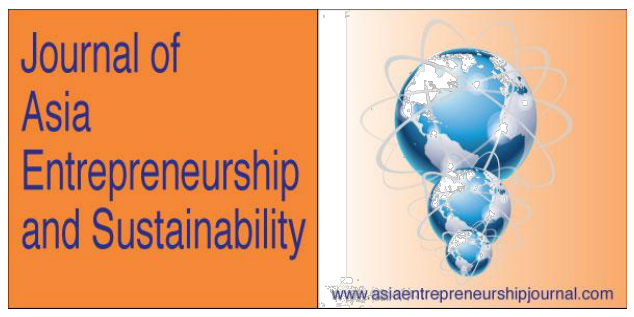

the slander. It must be stated that the European Parliament did its work properly, because the interaction with all actors and executive diplomats was at the level of greater readiness to overcome the crisis in Macedonia, proving political legitimacy and high mediation skills (conversation with ambassador French Minister in Skopje, Mr. Timonie, 15 September 2017).

\section{The implementation phase of the agreement (July 2015 - May 2017)}

Political arrangements are always difficult to achieve, especially in Balkan countries. It has been proven to be prone to hesitation and failure to fully implement them. The agreement that was reached immediately faced significant difficulties. One of the most controversial actions was the decision of state president Gjorgje Ivanov in April 2016 to pardon 57 political figures (including Prime Minister Gruevski, former country's prime minister and former SDSM leader Branko Crvenkovski, the newly appointed Public Prosecutor's Office, Mrs. Fatime Fetai, etc.), including personalities who had nothing to do with the interception of affairs. Ivanov's action caused a great revolt in public opinion, by which people again set off on the streets in Skopje and across the country to protest (also known as the "Coloured Revolution"). Under the pressure of the nationwide protests, but also under the pressure of the international factor, Ivanov was forced to abolish his decision. 


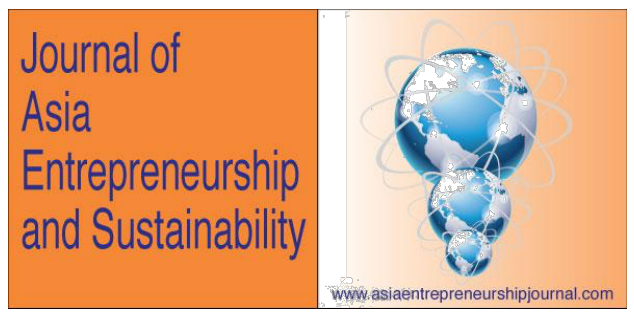

The parliamentary elections, according to the agreement, were set for April 2016, however they were postponed, initially for June and then for December 2016. The December election result, with a weakened VMRO-DPMNE in terms of international support for due to the wiretapping scandal, although it was awarded 1 deputy more than the opposition SDSM and, on the other hand, its partner for 9 years by the Albanian political bloc, DUI also for the first time after its formation as a political party that came out of the conflict in 2012 , lost many deputies, shrinking in total to 10 out of 19 in the last parliamentary composition. It was found under the constant pressure of the international factor (conversation with the French Ambassador to Skopje, Mr. Timonie, 15 September 2017), as well as the Albanian opposition deputies from the Alliance with the Coalition, together with SDSM had the numbers to form a new government, undermining the absolute domination of VMRO-DPMNE.

However, referring to the constitution, President Ivanov consistently refused to give SDSM Zoran Zaev the mandate to form a new government, not even the consecutive visits of EU representatives such as the Council of Europe's President, Donald Task, EU High Representative Mogeherini and Commissioner Hahn in the spring of 2017, but also the ongoing appeal of EU ambassadors and US ambassadors to the country, did not bring any results. Only after the violent events 


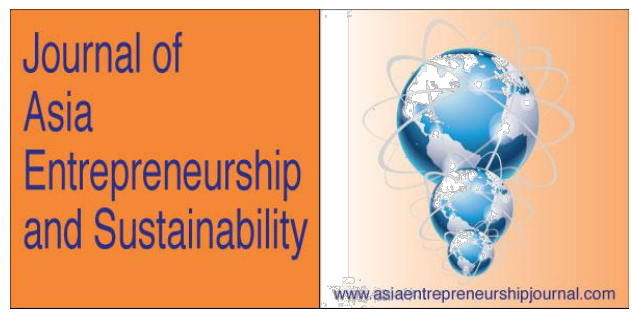

in the Parliament of Macedonia on April 27 2017, where Zoran Zaev and opposition deputies were attacked. Ziadin Sela the leader of the Albanian Alliance suffered the worst. Leader Sela who was beaten and threatened with death, brought the decisive turnaround and finally the new government with coalition LSDM-DUI and Albanian Alliance was established, while Zoran Zaev was elected prime minister of the country.

With the creation of the new government, the one-decade period, possibly the darkest in the history of Macedonia, ended, setting not only a nationalist-populist regime, but also changed political discourse, accompanied by hate speech, marginalization of non-Macedonian communities, especially Albanians, and raised the premise for a civic concept, focusing on the country's integration into NATO and the EU.

The Crowne of 3-Decade International Support to Macedonia was the Prespa Agreement (2019), which solved the name dispute with the Greece and from this year the country has a new name: The Republic of North Macedonia. 


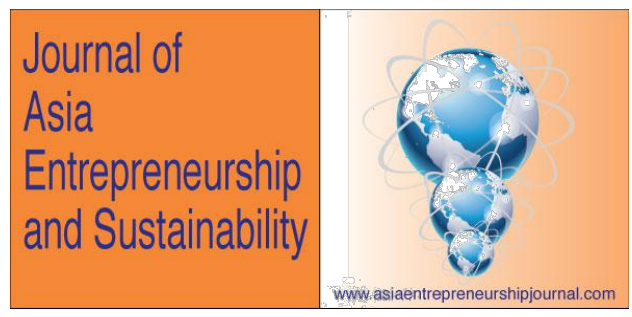

\section{Conclusions}

The historical circumstances, the nationalist spirit and the ethnic relief of Macedonia have influenced this Balkan space to always have problems both internally and externally, which problems have often and have sharply repressed the existence of this state. Consequently, the international intervention led by the United States and the EU in delicate cases such as the 2001 conflict, the 2014-2017 political crisis, and the management of the name constant with Greece, caused Macedonia to resist time as a state and to pave the way for Euro-Atlantic integration, but also to preserve inter-ethnic cohesion and establish permanent peace. 


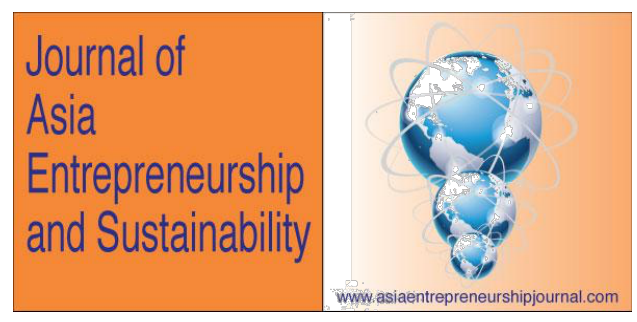

\section{References}

Fonck, D. (2018): "Parliamentary Diplomacy and Legislative-Executive Relations in EU Foreign Policy: Studying the European Parliament's Mediation of the Macedonian Political Crisis (2015-2017). JCMS, Vol. 56, Nr. 6, p. 1305-1322. Kacarska, S. (2015): "The EU in Macedonia: From Inter-ethnic to Intra-ethnic Political Mediator in an Accession Deadlock". In: Keil, S. and Arkan, Z. (eds) The EU ans Member State Building: European Foreign Policy in the Western Balkans. Abingdon:Routledge, p. 18-28.

Markovikj, N. and Damjanovski, I. (2015): "The uncharted political realm - social capital, political values and practices stimulating informal networks in Macedonia", New Balkan Politics, Issue 17, p. 10-28.

Weithmann, Michael W. (2000): Balkan Chronik: 2000 Jahre zwischen Orient und Okzident. Regensburg: Pustet.

\section{Sources}

European Commission Annual Report Progress for Macedonia, 2016a

Ina-Online (2017): Si u themelua dhe harrua Ilirida! April 8. Available online at: http://archive.ina-online.net/si-u-themelua-dhe-si-u-harrua-ilirida-2/

Macedonian Constitutions, 17.01.1992

Yugoslav Constitution 1974.

\section{Interviews}

Interview with the French Ambassador in Skopje, Mr. Christian Timonie, 15 September 2017. 


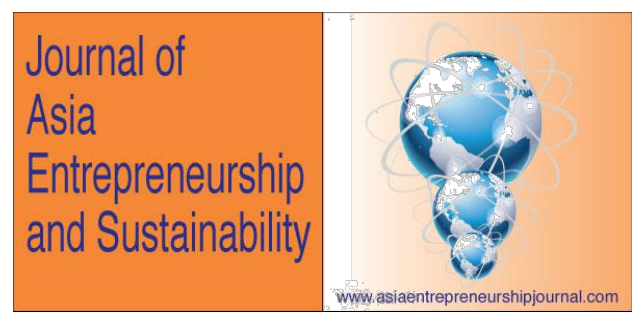

\title{
No is No, Maybe is No, Yes is Maybe: Issues of authenticity and accuracy from interviews with Vietnamese and Mongolian entrepreneurs
}

\author{
Mike Turner \\ Central Queensland University, Melbourne Campus, Australia \\ Richard Pech \\ Spandrel Education Group, Melbourne, Australia
}

\begin{abstract}
The following examines the challenges of cross-cultural entrepreneurship research, with a specific focus on the interview method. Challenges of the interview method are explained with guidelines for conducting cross-cultural research interviews. Examples are taken from the authors' research experiences while interviewing Vietnamese and Mongolian entrepreneurs. Risks and problems as well as solutions associated with qualitative research methods are discussed in an effort to acquire

Page 123

(C) 2019 Journal of Asia Entrepreneurship and Sustainability Vol XV, Iss 1, June 2019 RossiSmith Academic Publications, Oxford/London UK, www.publicationsales.com
\end{abstract}




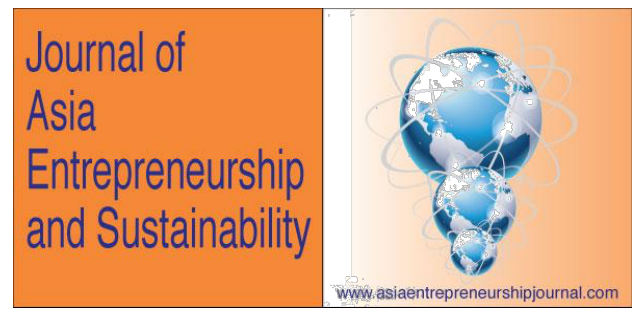

authentic and accurate results through a transparent and scientifically rigour process.

\section{Design}

This work is based on the authors' experiences while interviewing entrepreneurs in Vietnam and Mongolia. An emphasis is placed on examples of mistakes that can be made during the interview process as well as mistakes made in the interpretation and analysis stages and how these can be overcome.

\section{Findings}

The reliability and validity of the research interview is often 'taken for granted' in the business literature and as a research method its challenges are rarely explained. Interviewees will sometimes lie, or exaggerate, or misdirect the interviewer, or their words may be misunderstood. We discuss methods of guiding and managing interpreters, and dealing with issues of culture and language, as well as discussing the challenges of capturing, translating, and reporting truthful, authentic interview data.

\section{Page 124}

(C) 2019 Journal of Asia Entrepreneurship and Sustainability Vol XV, Iss 1, June 2019

RossiSmith Academic Publications, Oxford/London UK, www.publicationsales.com 


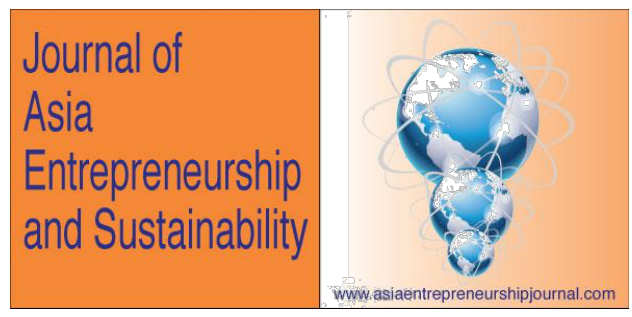

\section{Value}

There is an unspoken belief, particularly amongst business researchers, that interviews provide a relatively simple and accurate method for collecting data and that such data are generally truthful and reflective of the interviewee's reality. Using examples from history as well as our own experiences, we demonstrate that interviews, particularly when conducted in a cross-cultural context, hold many challenges and contain numerous traps for the unwary. We provide examples of these methodological problems as well as providing strategies for minimising their occurrence.

\section{Introduction}

Gephart and Richardson (2008); Young et al (2018), tell us that interviews are perhaps the most widely-used data collection strategy in management and the social sciences, but interviews can suffer from numerous methodological errors that include reliability and validity issues, issues of honesty and cultural sensitivity, and they can be costly and time consuming. Harkess and Warren 1993; Shazia, 2014), point out that interviewing must be regarded as part of a scientific process undertaken with complete strangers on the one hand, while having to establish a strong sense of rapport to establish validity on the other. Potential conflict caused 


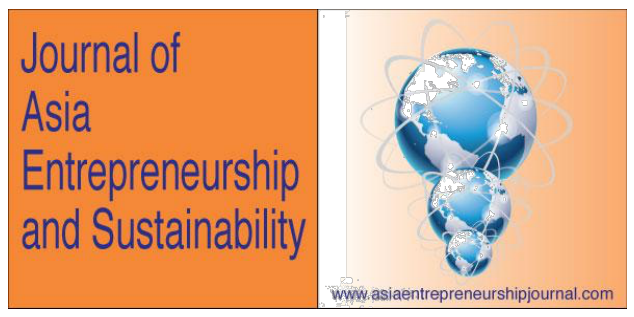

between the search for truth and having to establish rapport by demonstrating a sense of empathy, can create considerable tension for the interviewer.

Design and planning for undertaking interviews is critical to ensure efficiency and to satisfy the need for scientific rigour. For example Coughlin and Venkatesh (2003) discuss advances in research into the entrepreneurial activities of urban street gangs in the United States. Such research raises issues of criminality and violence, gender, codes of behaviour, and race and ethnicity, all of which must be treated with extreme caution and planning, and which may in many ways be as complex as conducting research into foreign cultures. Conducting interviews with members of an urban street gang in an attempt to elicit information about their entrepreneurial activities would be no less challenging than interviewing a Vietnamese village entrepreneur about his or her entrepreneurial activities in a socialist and still somewhat paranoid transition economy.

The following discussion will examine challenges associated with cross-cultural interviews, a research context which can introduce a whole new level of complexity for the researcher. Three decades ago Adler (1983) argued that published articles in cross-cultural management were few relative to the amount of international business activity. The degree and intensity of international business 


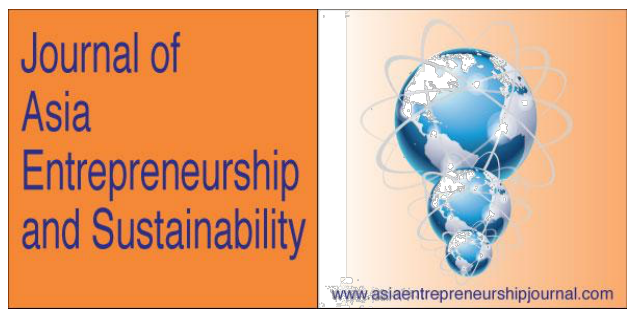

activity has increased considerably since Adler's comment was made and yet, information regarding the conduct of cross-cultural research is still comparatively limited in the business literature (Meuter et al., 2015).

Citing experiences and examples from the Australian authors' interviews of entrepreneurs in the transition economies of Vietnam $(n=55)$ and Mongolia $(n=35)$, issues of cultural and language differences, interview locations, the use of interpreters, researcher and interviewee expectations, and issues of honesty and the influence of introduced bias will all be examined. The interviews were conducted over several visits to Vietnam and Mongolia spanning a period of three years. Rather than confine potential subjects to a rigid set of definitional rules involving traits and behaviours, entrepreneurs were selected on the more loosely defined basis that they must be the founders of their business and for greater ease of identification, must have achieved local recognition for their business successes.

\section{The need for a rigorous and culturally appropriate interview process}

Veal (2005) claims that up to 80 per cent of management research has been conducted by North American researchers on Americans in American organisations. While attempts have been made to introduce a broader sample of nations to improve the cross cultural reliability of the entrepreneurial orientation 


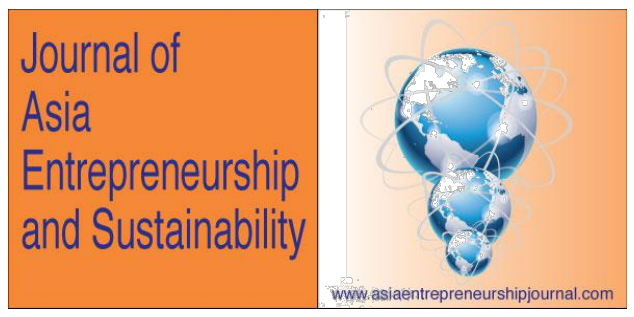

scale (for a detailed review, see Kreiser, Marino, and Weaver, 2002), and with the Babson GEM (Global Entrepreneurship Monitor 2017/2018, http://www.gemconsortium.org/) study (which at the time of writing already boasts more than 85 participating countries including Vietnam but not Mongolia), the bulk of these research efforts lack qualitative content and as will be argued, this omission can create a considerable gap in our knowledge of entrepreneurship in non-Western countries. Also, even when non-American cultures are involved in research using interviews as the main data collection method, interview-related issues are rarely discussed. For example, a search of the business research literature found that the complexity and challenges faced by an interviewer in a crosscultural context are rarely discussed. Of all the literature examined, interview guidelines appear most commonly in the medical literature (for example see Jaya, Hindin and Saifuddin, 2008; Schwerdtfeger, 2009) but are more difficult to find in the business literature. This seems surprising. Brämberg and Dahlberg, (2013) state that studies examining methodological concerns in cross-cultural interviews are limited, while randomly selected interview-based research by Benevene and Cortini, (2010), Hobbs, Anderson, and McKechnie, (2009), Hughes-Scholes and Powell (2008), Robinson (2014); and Thai (2010) all describe the authors' findings but give no indication of how or where their interviews were conducted. Such omissions could justifiably cast doubt on the veracity of their findings. According 


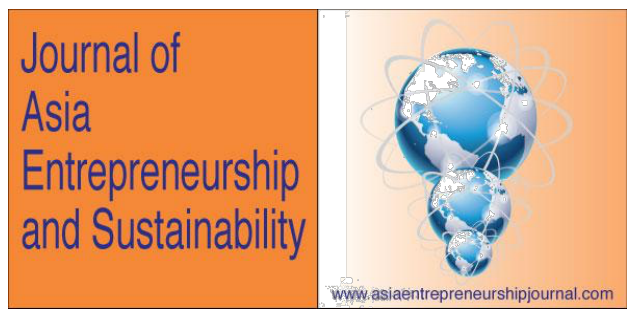

to Freeman (1997) the discipline of anthropology has never recovered from the legacy left by Margaret Mead and ongoing accusations of a lack of rigour in her research. According to Freeman, her mistake was not in forming the wrong narrative to fit her data but in not finding corroborating evidence to support what she had been told by her informants. That she appears to have been deceived by two mischievous Samoan informants and went into print with her apparently mistaken findings describing Samoan cultural promiscuity has, according to Shermer (2005) triggered a century-long anthropology war. Such controversies can and must be avoided in the entrepreneurship field.

\section{The interview method}

The interview method should not be taken for granted, as with any data collection method, inaccuracies or inappropriate application may expose the researcher to a host of potential difficulties. De Jong, Anh Tu, and van Ees (2012) conducted a series of interviews in Vietnam and carefully explained their interview method. This was particularly important as they were researching entrepreneurs and their willingness to bribe government officials. Such sensitive information cannot be gathered in a careless manner. De Jong, Anh Tu, and van Ees (2012) used local university students who were deliberately chosen because they were younger than the entrepreneurs, thus not posing a threat, and they were able to speak in the local 


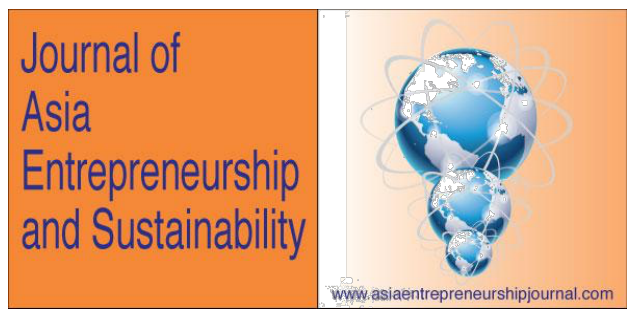

Vietnamese dialect, which was intended as a means of reducing suspicion. By including this important additional information, these authors are able to lessen fears concerning cultural reliability.

Holloway (2005) refers to the qualitative interview as a conversation with a purpose' and as such the intention is to learn something about the person being interviewed rather than simply providing a vehicle for the interviewee to voice a random set of thoughts. Kemmis (1985) explains that the interview process is dynamic in that the researcher is actively engaged in a learning procedure during the interview, gaining a new perspective on the respondent's situation. Holstein and Gubrium (1995) view the interview as a social encounter that leads to the possibility that rather than being a neutral conduit or source of distortion, the interview is a productive source of useful data - but this is only true if the potential pitfalls of the cross-cultural interview process have been managed. In other words, the research interview should be seen as less of a 'panning' process in search of random nuggets of gold, and more of a structured 'mining' operation in search of the mother lode. The mechanism of the interview process cannot therefore be left to luck or chance.

\section{Potential cross-cultural pitfalls and challenges}




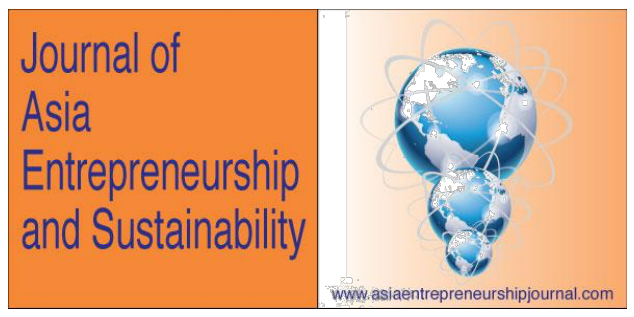

As an example of one of the potential pitfalls of cross-cultural research, an interviewee, a Hanoi-based entrepreneur, confided to the authors that he would have been reluctant to answer any of the questions honestly had he not had a preexisting relationship with the interpreter or the authors. This revelation came about before he responded to the authors' question about failure in business. Crossley (2000) highlights the problematic nature of attempts at openness, explaining that the more distant a relationship, the greater the restraints on how open and honest a respondent may be with a researcher. Without relationships in place the true story may never unfold, and according to Wright and Nguyen (2000) and Tuang and Stringer (2008), working through relationships may be the only feasible way to gain access to respondents from other cultures. In the previous example, the entrepreneur admitted that had the authors interviewed him without the "known and respected" interpreter being present, he would have lied about the failure of his earliest business ventures. When probed further, he explained that he would have wanted to save face in front of a foreigner and also, as there was no tangible relationship in place, he felt no obligation to tell the exact truth.

The above admission was repeated in some form 7 times amongst the 55 Vietnamese entrepreneurs and 4 times amongst the 25 Mongolian entrepreneurs 


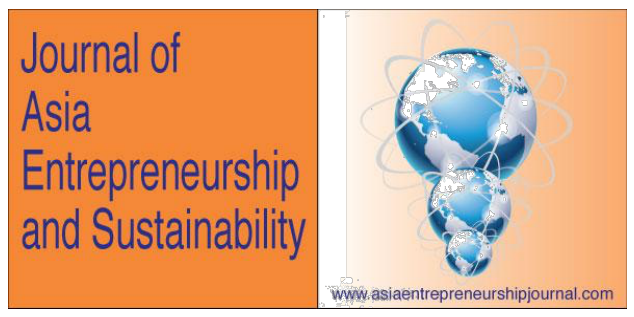

when interviewees were asked about their experiences with venture failures. The topic of business success was readily discussed; the topic of business failure was taboo or only acknowledged reluctantly once interviewees felt completely at ease with the interviewers. They then grudgingly admitted their failures but were quick to add that each failure provided lessons that helped them to start and succeed in their current business ventures. Cultural sensitivities, cultural paranoia, and personal quirks and fears can all influence the reliability of interview data, potentially contaminating the unwary researcher's results. A researcher who has not established a relationship with interviewees could for example be led to believe that business failures in Vietnam and Mongolia are non-existent because information about failure is not freely offered to foreigners (or locals for that matter - unless they have an established relationship).

\section{The problem of introduced bias}

Without an accompanying narrative, cultural artefacts may be easily misinterpreted through introduced bias. Wade (2006) reports an amusing and yet also sobering example when he describes the influence that contemporary ideologies have upon interpretations of the past. He explains that some archaeologists, wishing to 'pacify the past', have interpreted the large number of copper and bronze axes unearthed from late Neolithic and Bronze Age burial sites to be not battle axes but a form of 


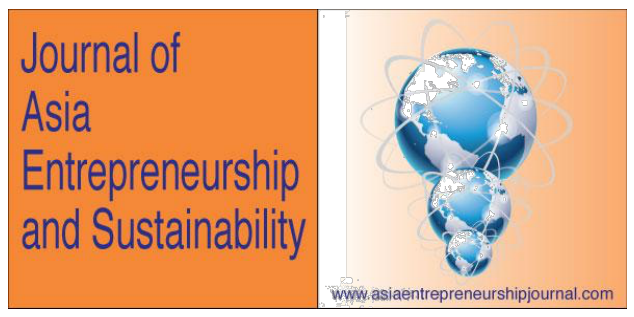

money. He uses the example of the intact 5000 year-old man discovered in a melting glacier in 1991. The well-preserved corpse was found with just such a copper axe and he cites Keeley's (1996) tongue in cheek comment that the corpse was found 'with one of these moneys mischievously hafted as an axe. He also had with him a dagger, a bow, and some arrows, presumably these were his small change' (Keeley cited in Wade, 2006, p. 154). Later x-rays of the corpse revealed a fatal chest wound with an arrow-head, strongly debunking the mistaken view that his was a life of peace and tranquillity. Romanticized notions of the noble savage could finally be put to rest.

Searle (1995) echoes Keeley's concerns when he points out that 'Actual human efforts to get true representations of reality are influenced by all sorts of factors cultural, economic, psychological, and so on. Complete epistemic objectivity is difficult, sometimes impossible, because actual investigations are always from a point of view, motivated by all sorts of personal factors, and within a cultural and historical context.' It is extremely difficult not to superimpose the biases and legacies of ones own cultural heritage when coming into contact with another culture. As argued by Kuhn (1962), it is easy to see what one wants to see when given the option of choosing the data with which to defend a personal paradigm against falsification. 


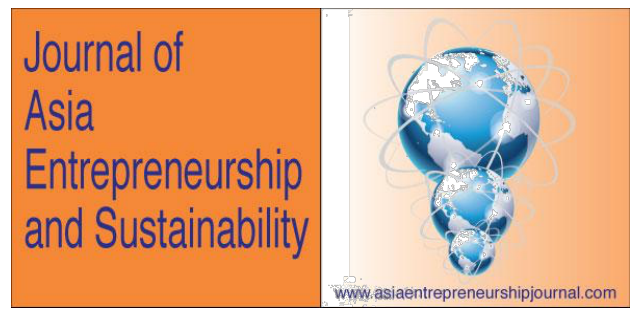

\section{Problems with narrative methods}

The above arguments support Soin and Scheytt's (2006) call for multimethodologies as the best way of injecting rigour into research. Soin and Scheytt (2006) argue a compelling case in support of narrative methods to verify findings by other means, although they too can be fraught with risks.

Narrative methods are always open to interpretation. Statistician Nassim Taleb points out that:

'you can find an infinity of narratives to fit your data' ... and we may sometimes 'concoct empirically flawed narratives to explain past events which may make us overestimate causal links between events' (Taleb, 2006, pp. 50-51).

Taleb's comments point to complications in the narrative method, potentially causing problems for the naïve researcher:

1. Interpretation of such data is subjective and open to bias

2. Apparent patterns may not be patterns at all

\section{Page 134}

(C) 2019 Journal of Asia Entrepreneurship and Sustainability Vol XV, Iss 1, June 2019 RossiSmith Academic Publications, Oxford/London UK, www.publicationsales.com 


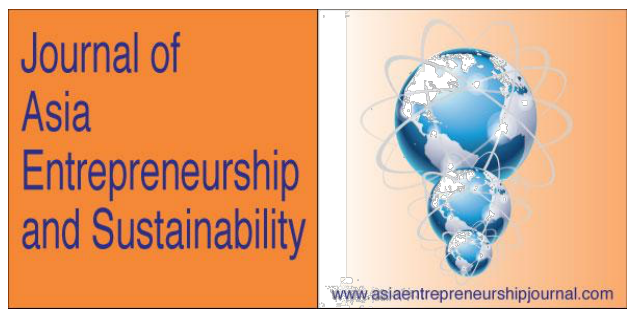

3. Narratives may be unreliable, entirely fictitious, or at best exaggerations of the truth

Under such conditions of uncertainty, the qualitative researcher must find further means of constructing knowledge, hence Soin and Scheytt's (2006) argument for multi-methods as one means of injecting rigour into qualitative research. But what if there are no other means of finding corroborating evidence such as statistical data to suggest the existence of indicative patterns? For example, attempts at acquiring Internet usage data and growth in Mongolia have been met with blank looks and dead ends (Turner in Pech, 2009). Under such conditions of limited data access, the researcher may be forced to use a single-method approach such as interviews, increasing the risk of uncertainty and bias. While a lack of corroborating evidence may pose a problem for researchers, our Vietnamese and Mongolian entrepreneurs viewed such difficult circumstances as opportunities. As an example, one Mongolian entrepreneur described how the shortage of medicines in Mongolia prompted him to grow herbal remedies. His rapid success resulted in expansion into the manufacture and export of a wider range of pharmaceutical products. Upon discovering that there were too few pharmacists and pharmacy outlets to distribute his products, he became instrumental in founding a university in Ulaan Baatar, the capital of Mongolia, so that he could employ graduates with 


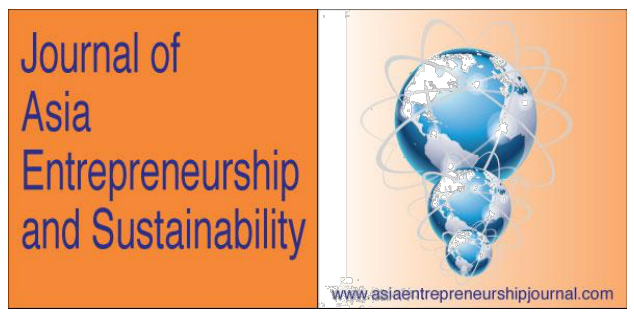

the appropriate pharmaceutical qualifications and thereby continue to grow his business. This entrepreneur's visionary and opportunity maximisation strategy appears clear enough when presented in this discussion. But the entrepreneur did not perceive his actions as planned, or even as an example of entrepreneurship. He simply viewed himself as a problem-solver. His remarkable experiences had to be extracted through numerous iterations of the question, 'what did you do then?' The entrepreneur did not have a prepared narrative of his business experiences and was only able to relate these in a very unstructured manner through the interviewers' constant prompts and questions. In this sense the interviewers became a part of the narrative by providing the narrative structure as well as the analytical lens (entrepreneurship) through which to view this man's innovative and visionary problem-solving skills. Alternative medicine researchers interviewing this man might completely ignore his entrepreneurial skills and frame his achievements purely through a scientific paradigm, perhaps drawing new insights into the science of alternative medicines while remaining completely oblivious to any entrepreneurial/business implications.

Leshkowich (2006) attempts to introduce elements of transparency and scientific robustness into her account of one female Vietnamese entrepreneur by noting the limitations of her research early in her article (pp. 278-279). These correctly

\section{Page 136}

(C) 2019 Journal of Asia Entrepreneurship and Sustainability Vol XV, Iss 1, June 2019 RossiSmith Academic Publications, Oxford/London UK, www.publicationsales.com 


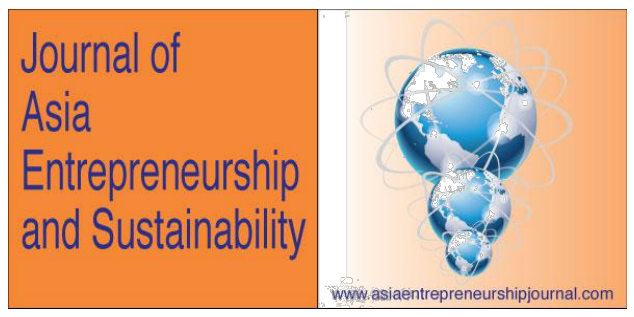

include a description of potential reliability problems associated with her interviewee's description of her own life, the fact that none of the remarks can be verified by observation, and that her account of her own life can not be used to infer similar thoughts and experiences across a greater part of the population. Leshkowich (2006, p. 279) does however cite an interesting quote from LéviStrauss $(1963$, p. 89) in an effort to mitigate any methodological weaknesses, 'What one person's story can do, is offer a rich, unique perspective that is good to think.'

Lévi-Strauss' statement attributes value and significance to one person's story, and this is echoed by Yin $(2003$, p. 39) when he states that 'a single case study is analogous to a single experiment, and many of the same conditions that justify a single experiment also justify a single case study.' But a researcher's problems may commence long before arguing in support of the single case study. Soucy found even that to be a challenge as he couldn't get any Vietnamese women to respond to his research questions because "they did not consider themselves knowledgeable; instead they devalued their own knowledge to the extent that they themselves doubted it ... Their silence was a statement about the feelings they had regarding their position rather than a statement of ignorance' (Soucy, 2000, pp. 183-184). It could therefore be misrepresentative to simply interview those who 


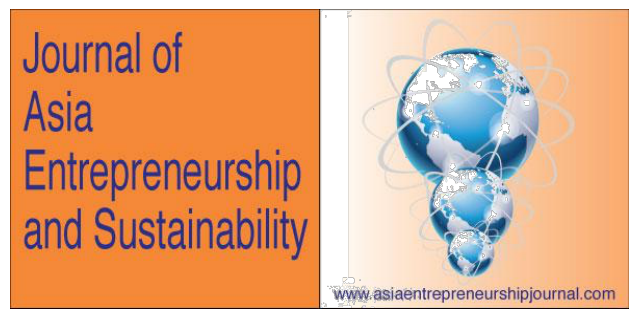

believe they have something to say. Such an approach may exclude people, such as the Vietnamese women, whose opinions and thoughts have been culturally muted, but which are nonetheless valuable as key pieces for understanding the rich mosaic comprising that society.

\section{Truth and accuracy}

Where the researcher is able to find willing interviewees, the truthfulness and accuracy of their statements should also be examined through supporting evidence, and any other means of authentication. Briggs (1986) warns that some researchers base their interview strategies and the way they interpret the data on a number of false assumptions. Relying on their own speech and language routines, they are deprived of a sufficient awareness of how the data they receive fits into the cultural patterns of thinking, feeling and speaking of the respondent.

As an example, Lincoln (2008) reports on the Vietnamese Government's 2008 ban on some street vendors in parts of Hanoi and its consequences upon microentrepreneurs. She explains that with the banning of the street vendors there has been a significant growth in the more well-known fast food firms such as KFC, but that the fastest food on the streets of Hanoi is still in the 'form of the street vendor with her produce running from the cops' (Lincoln, 2008, p. 265). It is therefore not 


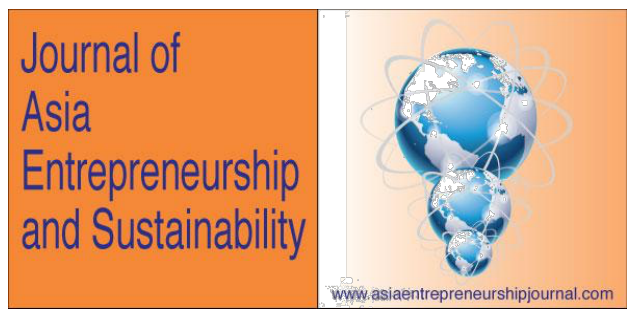

surprising that street vendors in Hanoi are reluctant to talk to strangers about their business practices. A naïve researcher would be unaware of the reasons for the vendor's caginess and her reluctance to be interviewed. Prior knowledge of such cultural idiosyncrasies would be extremely helpful to the researcher. Such cultural nuances, or emic traits, are the phenomena or assumptions specific to a particular culture (Cavusgil and Das, 1997), and these must be understood as a pre-requisite to the study of a culture that is not your own.

\section{Cultural nuances - 'I may say what you want to hear'}

There is ongoing debate on the gradual seepage of Western culture into Asian cultures. Phongpaichit (1999) suggested that Western ideas and colonial practices have been eagerly adopted throughout Asia in an attempt to become 'modern'. That being said, there remain distinct cultural nuances in both Vietnam and Mongolia of which the researcher must remain acutely aware.

Unlike the general view held by Westerners, there is within Asian cultures a propensity to please and as such people do not like to say "no" (Talib, 2010). This issue of "reflexivity" or as explained by Everett (2002, p. 71,), "the need to consider one's relation to the research object" requires the researcher to be acutely aware of his or her contribution to the construction of meanings throughout the 


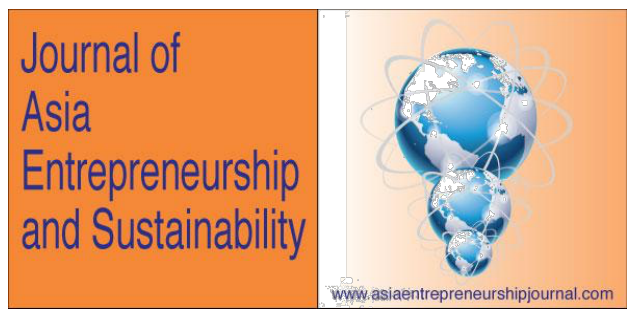

research process. According to Hardy, Phillips and Clegg, (2001), reflexivity involves reflecting on the way in which research will be carried out and understanding how the process of conducting research may shape its outcomes. Therefore prior to conducting research in Vietnam and Mongolia, the researcher must acknowledge that it is impossible to remain impartial and must reflect on the ways in which personal values, experiences, interests, beliefs etc. may influence the research (Avison and Wood-Harper, 1991; Huxham and Vangen, 2003).

In an attempt to recognise that it is psychologically impossible to remain impartial and objective while conducting research Nightingale and Cromby, (1999, p. 228), suggest that reflexivity encourages the researcher "to explore the ways in which a researcher's involvement with a particular study influences, acts upon and informs such research."

In addition, Asian cultures command respect for elders and as such older people are held in high esteem and always treated with respect (Giles, et al., 2003). This may pose a problem in that it is possible that the majority of respondents in both countries will be younger than the researcher. People in both Vietnam and Mongolia are respectful to elders and therefore naturally agree to whatever may be said even if they have doubts about its accuracy. Therefore when conducting 


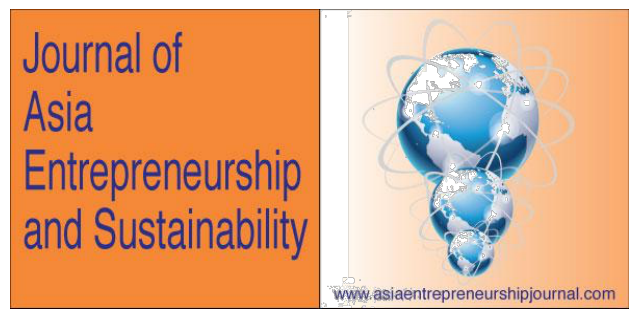

research, it will be important to understand that it may not be what is said, but how it is said, that will provide the correct message.

Cultural research and understanding may therefore be inhibited as:

1. the interviewee may be unable or unwilling to accurately and/or freely communicate his or her reality,

2. the interviewer may be unable to interpret or receive what the interviewee is attempting to communicate, and this may sometimes be due to ethnocentrism where one cultural group holds a view of their own culture's superiority or through some other form of introduced bias,

3. cultural taboos, inhibitions, and practices may deter an interviewee from relating an activity or event in its entirety or as it actually occurred,

4. the interviewee may, for a variety of reasons ranging from cultural politeness through to fear or deliberate deception, give entirely inaccurate accounts of motivations, activities, or events, and

5. the interviewer may identify only willing participants whose stories are nonrepresentative.

Emic traits or political and cultural sensitivities must be understood, and carefully 'managed' before the cultural researcher can hope to embark on a journey of true 


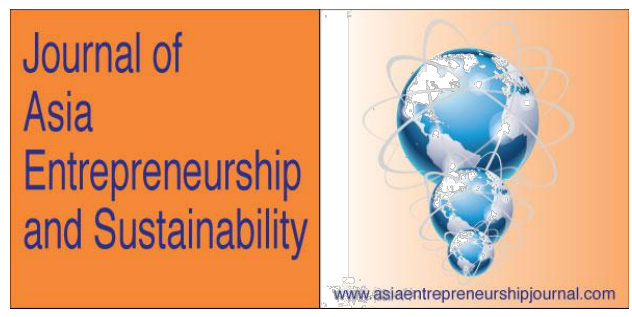

and accurate discovery. As one means of managing such sensitive issues, Gephart and Richardson (2008, p. 35) recommend the use of critical postmodernist techniques to improve understanding and identify potentially constructed, or contradictory reality as well as hidden interests and alternatives.

Gephart and Richardson (2008, p. 35) explain that critical postmodern research uses qualitative methods to examine discourse and to uncover evidence of reified structures and hidden contradictions, and alternative interpretations - a useful paradigm for meeting the challenges of cross-cultural research. Such an approach attempts to probe beneath superficial, confusing, or suspicious interview responses, examining not only their validity, but also the reasons for giving such responses.

The research process must therefore be a carefully planned investigation, which should commence with a thorough understanding of the culture about to be placed under scrutiny. One method of doing this, aside from vicariously studying any literature describing the culture, is through the use of interpreters. 


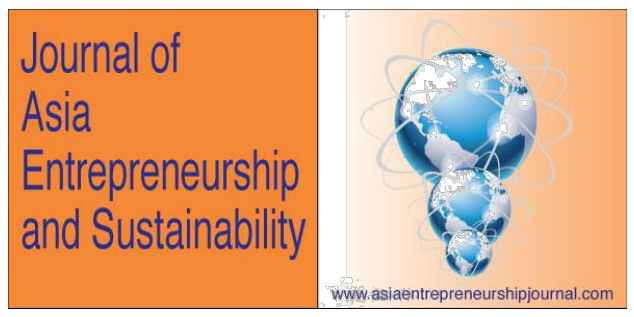

\section{Interpreters: providing cultural context}

According to researchers such as Kong, (1998); Lim (2010); Napier, Hosley and Nguyen (2004) and Noble, (2005), the concept of providing information to strangers is not acceptable in Vietnam and other Asian nations. Hussain, Scott, Harrison and Millman (2010) add that although there is an open door policy throughout Asia, in many destinations foreigners are still perceived as exotic and unfamiliar and are therefore not trusted. Suspicions of foreigners' motives, high levels of personal machismo and ethno- and male-centrism, fears of prying and corrupt governments, and concerns about the actions of unethical competitors may serve to feed deeply-seated fears that collectively engender a sense of paranoia within foreign business communities and engender a reluctance to participate in an all-revealing interview (Beals and Woolfolk 2006; Holstein and Gubrium 2003; Luo, 2002; Smith, 2006). The establishment of trusting relationships could take time that the researcher cannot afford, hence the need for a trusted interpreter who will not only mitigate the effects of cultural paranoia, but can quickly facilitate a relationship of trust and acceptance that will encourage a useful dialogue between interviewer and interviewee.

Relationships dominate all aspects of life and as such personal introductions are critical. The credibility of those making the introductions is all-important and it 


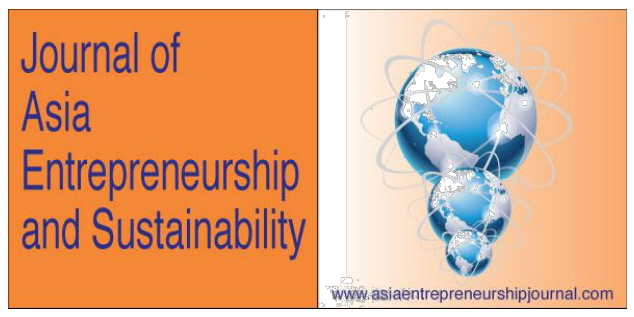

enables the researcher to gain access to people who otherwise would have been unwilling to meet with strangers. Because Mongolian and Vietnamese people hold common suspicions about strangers and in particular foreigners, trust in a researcher can be granted vicariously through the relationship that already exists between the respondent and the interpreter (Dana, 2000; Friedland and Penn, 2003; Suzuki, Ahluwalia, Mattis and Quizon, 2005). Javier (2007) proposes that in multilingual communities such as in Vietnam, the need for translation of information becomes inevitable for the non-Vietnamese researcher.

In all of the Mongolian and Vietnamese research interviews undertaken by the authors, the respondents had no obligation to participate, however they did so willingly due to their connection with and trust in the interpreters. Numerous researchers recommend that interpreters should have well-established links with their respondents and that the researcher should confirm that they are respected and trusted by them (Temple and Edwards, 2002; Wallin and Ahlstrom 2006; and Witzel, 1989). This was evident in all interview situations undertaken by the authors. As such, the interpreters proved valuable in providing a cultural context to this study beyond the basic task of interpreting. Welch and Peikkari (2006) point out that interpreters are often able to establish deeper rapport with the interviewees than a researcher can achieve and that this provides interviewees with the 


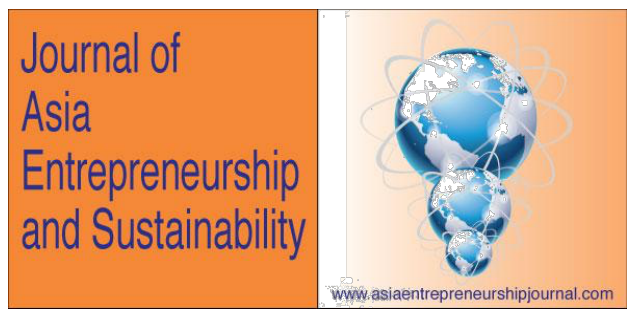

opportunity to express themselves in their native language, thereby producing more authentic answers that exhibit 'more subtle nuances' (p. 428).

Sometimes even an understanding of the language is not enough for the researcher. A study by Locander, Sudman and Bradburn (1976) found that falsification to responses increased sharply as the perceived threat to the interviewee increased. Stamboulidis (2009) warns that within a research interview context, elements of deliberate deception may be difficult to avoid. As such, without trusting relationships in place, data may at best be flawed or at worst, totally useless. According to Soin and Scheytt (2006), in essence the researcher is attempting to interpret relevance from respondents' stories in that they echo the voice, thinking, and perceptions of a larger group of people. From a researcher's perspective, truth, openness and honesty are critical as anything less may invalidate or corrupt the research and thereby justifiably open it up to criticism and debate, as was the case with parts of Margaret Mead's Samoan-based research.

Scott, Miller and Lloyd (2005), three young, non-Vietnamese, and female doctoral student researchers, identified three factors that inhibited their ability to secure participation from respondents in their study of ethnic Vietnamese groups. The factors were: 


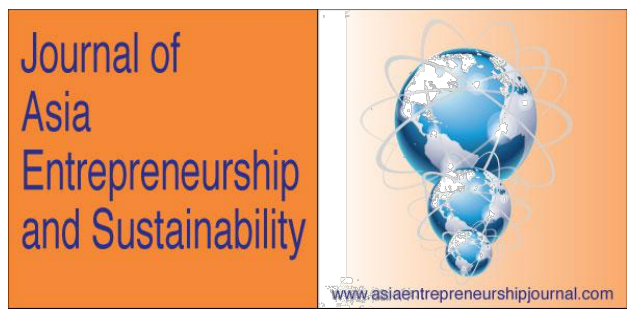

- The length of time required to cultivate appropriate levels of trust

- Raising the expectations of respondents that their participation would lead to tangible benefits

- Asking respondents to give up their time for an interview that would possibly not result in the return of specific benefits to participants.

Scott, Miller and Lloyd's (2005) experiences raise another dilemma for the researcher's goal of securing accurate and authentic data. Potential respondents in Vietnam and Mongolia may be willing to submit to an interview because by doing so they hope to receive some type of tangible benefit. If the researcher is perceived to be unable to provide such benefits, then potential respondents may be difficult to find.

This problem was identified during the authors' research in Vietnam and Mongolia. Business owners were happy to volunteer to be interviewed, provided that in turn they were able to receive marketing and management advice from the authors. This created a dilemma, as respondents became over-zealous in their efforts to please the authors and speed through the interview so that they could ask their own questions, increasing the probability of interviewees incorrectly responding to the research questions and thereby corrupting the data. To offset any 


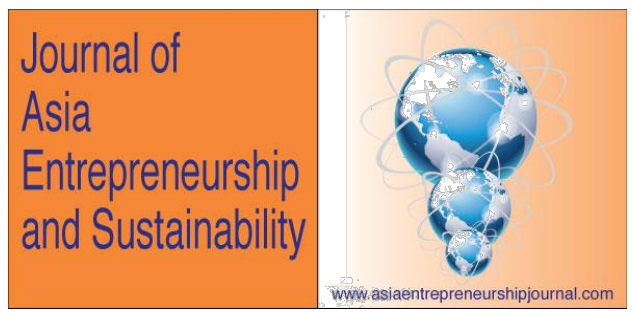

over-zealous willingness to please, the interpreters were instructed to ask the respondents to cooperate fully and answer as if the interpreters personally required the information. Most of the interpreters took this instruction further and requested that the authors be treated as confidants and friends. They suggested that the authors be accepted into the circle of friendship that existed between the interpreter and respondent. Following the interviews the authors provided consultative services at no charge in order to meet their interviewees' cultural expectations for reciprocity. In both countries business consultation is out of the financial reach of small business owners. Any opportunity to gain knowledge is highly prized and these business owners made it very clear that they expected to receive access to the authors' business knowledge in 'payment' for their participation in our research project. It was found that the interpreters were the key link to defuse any potential interviewee expectations of the interviewer but even they were unable to procure useful and willing respondents without the offer of free business advice from the authors.

\section{Language}

According to Kluckhohn (1954), "culture is to society what memory is to individuals" and as such successful intercultural communication is very difficult to achieve. It may be very difficult to gather valid and reliable data using English in a 


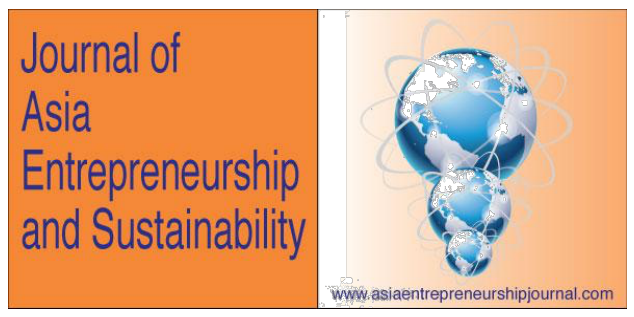

non-English speaking environment (Briggs, 1986; Hussain, Scott, Harrison and Millman, 2010). Bridging the gap between people who employ an interpreter because they do not speak the same language can be a very delicate task (Pistillo, 2003-2004). What is said may not be as important as how it is said and how it is interpreted in the target culture. It may be what separates research that will add to the body of knowledge from data that is inaccurate and therefore useless (Herdman et. al, 1998, cited in Sidani et al., 2010: Hussain, Scott, Harrison and Millman, 2010). Understanding how language and culture can impact research and finding ways to minimise cultural barriers in the research process is a critically important task for the researcher (Berrell, Wright and Tran, 1999; David and Rhee, 1998; Bird, Wiles, Okalik, Kilabuk, and Egeland, 2009).

In conducting cross-cultural research, Jentsch (1998) suggests that language has been recognized as a methodological issue that requires careful assessment by a researcher. Westermeyer and Janca (1997) support this where they suggest that the choice of language in which to interview becomes an important consideration especially in Asian cultures where self esteem and face can intrude. In countries such as Vietnam and Mongolia it is therefore desirable to conduct interviews in the language of the interviewees. Alvesson and Sköldberg's (2000) warning that data translation is messy, thus providing limited capacity to convey 


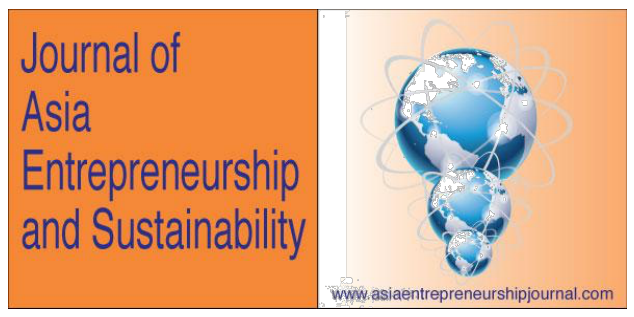

knowledge of a purely empirical reality, further serves to strengthen the role of the interpreter as more than someone who simply translates words. They must attempt to convey the full emic implications that underlie the responses or stories of the interviewee, and are therefore critical for interviewee introductions, relationship establishment, communication of the actual interview, and translation of the interview data.

\section{The interpreter as active contributor to the research}

The role of the interpreter has been strongly emphasised and as Scott, Miller and Lloyd (2005) state, fieldwork is strongly shaped by their role in the process of gathering data. According to Avery (2001) the interpreter should be considered as the manager of a cross-cultural mediated encounter. This defines their role as the facilitator of the communication process between people who do not speak the same language. The goal then is to ensure that the researcher's objectives are met. Gephart and Richardson (2008, p. 41) emphasise that the active approach to interviewing is especially appropriate when the researcher is interested in subjective interpretations or processes of interpretation. Pitchforth and van Teijlingen (2005) revealed in their study that using an interpreter in a traditional passive role introduced tensions into their research interviews and was burdensome for the participants. The authors then stated that they adopted an alternative 'active- 


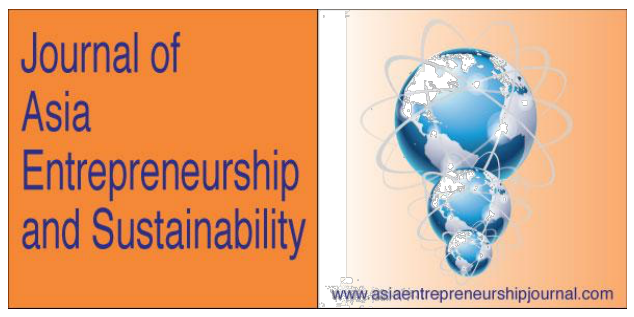

interpreter' model (Pitchforth and van Teijlingen, 2005, p. 4) that gave the impression of overcoming these tensions but did so by effectively excluding the researcher for part of the interview. Interpreters should be active in that they negotiate between two cultures and establish ties of trust and respect but they must also keep the researcher involved and informed in the entire process.

As an example, during one of the authors' interviews in Vietnam the interpreter did not immediately decode and disseminate what was said by the interviewee. Instead she engaged in a conversation that went back and forth for several minutes. The researchers were totally ignored during both discussions. After these exchanges the interpreter then related the information to the researchers. Following the first occasion on which this happened, the interpreter was asked (during a post interview debrief session as suggested by Wallin and Ahlstrom, 2006) what had transpired. The interpreter replied that she did not believe the information offered was a true representation of the interviewee's situation. Therefore she asked him to reconsider the question and answer in the spirit of co-operation and friendship to her and to the researchers.

It was revealed that the interviewee wanted to embellish on the wealth earned in his business, when the interpreter knew it was an exaggeration. The interpreter 


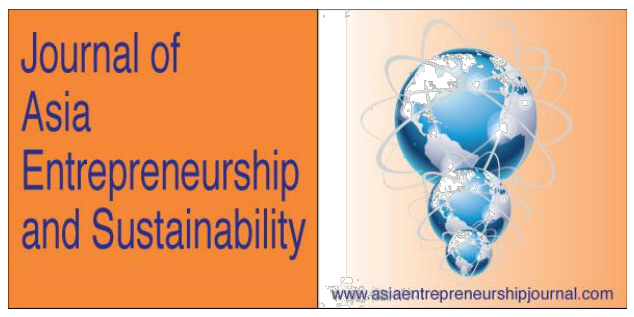

could have simply interpreted the interviewee's claims or told the truth without translating however she wanted the respondent to supply the information without influencing the flow of the interview. On a second occasion the interviewee wanted to make light of a question and deceive the researchers. The interpreter would not tolerate this type of behaviour and appeared to let the respondent know in no uncertain terms that his frivolity could jeopardize the quality and accuracy of the research. Such corrective feedback would never be possible if respondents were simply to complete a survey or other form of quantitative data collection.

The above examples support the role of interpreters and their importance to a researcher. In taking a passive role, an interpreter's efforts may have resulted in data inaccuracy (Kaufert and Koolage, 1984). However, according to Davidson (2000), it is the interpreter as the only conversational participant, who is able to follow both sides of the cross-linguistic discourse. They are uniquely positioned to control the flow and quality of information. They are also able to employ interrogative techniques as defined by Zikmund, Babin, Carr and Griffin (2010, p. 114) where answers can be revisited with multiple what, where, who, when, why, and how questions.

Van Rekom, van Riel, and Wierenga (2006, p. 181) describe an interrogative technique called laddering where the interviewer might ask 'what do you do in 


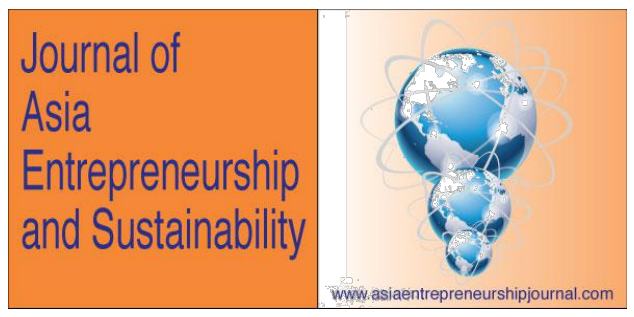

your work?' This might be followed with questions such as 'why do you do it that way?' and 'why is that important to you?' According to the authors, this technique is designed to uncover 'whole ladders of means and relations'. Such comprehensive interrogative techniques are not available to survey methods and therefore demonstrate the advantage of interviews as a means of collecting extremely detailed and possibly more reliable information.

Interpreters must therefore be briefed with the intent of establishing the importance of the study and the relevance of maintaining data integrity by probing the interviewees for accuracy and deeper meaning using methods such as laddering techniques. Interpreters must accept their roles as linguistic and social intermediaries. Far from merely conveying the words of a researcher and the interviewee, they are central to the achievement of the interactional goals and as such a significant degree of responsibility rests on their shoulders (Davidson, 2000). Ideally they should see their function as not only providing cultural context but also as supports to a researcher by acting as cultural consultants (Goldstein, 1995; McCaffrey, 1999-2000). The generation of accurate data is at all times the objective. But sensitivity to the manner in which that data are presented can add a depth of understanding that would otherwise not be possible from a simple regurgitation of the interviewee's responses. 


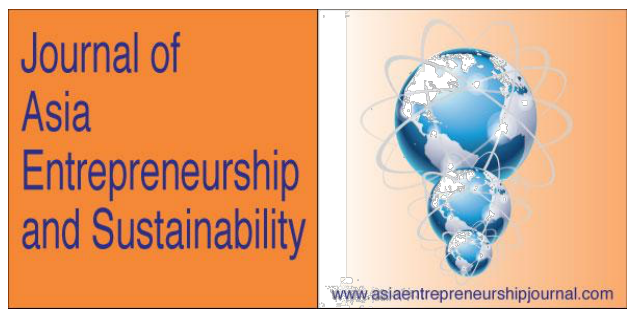

\section{Interpreter skills}

Thus far it has been argued, as Whiteford and McAllister (2006) have stated, that research involving people from other cultural and language groups demands highquality interpretation and that this is a critical component to the outcomes of the study. The role of the interpreter in any cross-cultural research should be to encourage participation, provide an understanding of the methodology, explain customs to the researcher/interviewee and clarify the concepts used within the cultural context (Farooq and Fear, 2003; Mullamaa, 2009; Wallin, 2007; Escotet, 2018).

Laverack and Brown (2003) in their research found that their Fijian interpreters at times tended to lead the discussion and took a directive (railroading) rather than a participatory approach and encouraged discussion but did not try to involve all of the participants (loss of rapport). A major objective of any research interview is to avoid the above pitfalls. In order to do this, there should be a concerted effort to ensure high level understanding of the research aims and to elicit fully supportive buy-in by the interpreters. In addition, before approaching the actual respondents, several "mock" interviews should be held with volunteer subjects. These pilot interviews enable the researcher and interpreter to hone their interviewing skills, and assist in negating the potential for personal bias (Stewart and Shamdasani, 


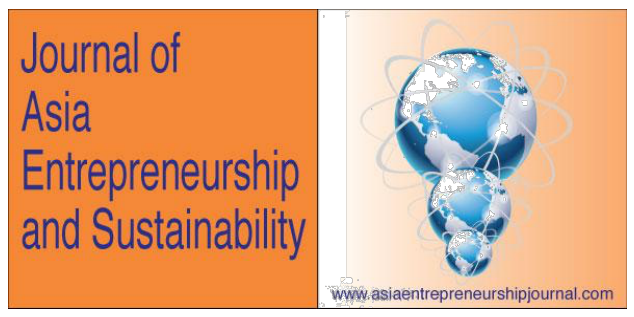

1990; Piekkari and Welch, 2005). Further, they are vital in developing a practiced, consistent and co-ordinated interviewing standard, thereby facilitating internal consistency reliability. This use of a partisan approach to interviewing facilitates the aim of maintaining full engagement during each meeting and capturing actual, useful, and truthful data.

Further, there is a correlation between the level of interpreter-researcherrespondent engagement and credibility, and the degree of data accuracy achieved. The higher the level of engagement, credibility, and methodological robustness, the greater the probability of data and interpretational accuracy. Scott, Miller and Lloyd's (2005) problems with gender and age and their inability to gain quality information from their interviews as well as being unable to guarantee data accuracy could spell the end of their research project.

\section{Age and gender}

Scott, Miller and Lloyd (2005) reported that being young female students created barriers to gathering data. They were able to build rapport with females however as they could speak some Vietnamese, but they were unable to develop an appropriate bond with males. Their experience is supported by the work of Benney, Riesman and Star (1956); Kane and Macaulay (1993); Catania et. al (1996), who found that

\section{Page 154}

(C) 2019 Journal of Asia Entrepreneurship and Sustainability Vol XV, Iss 1, June 2019 RossiSmith Academic Publications, Oxford/London UK, www.publicationsales.com 


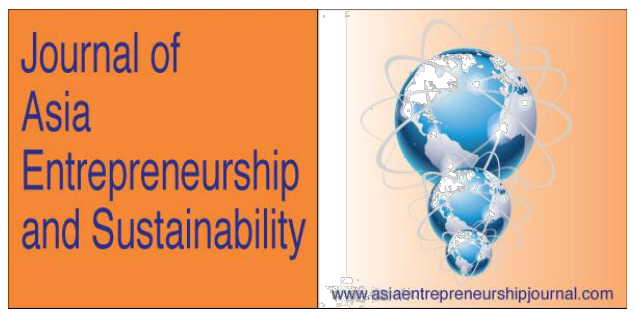

female interviewers obtained their most accurate responses from women in similar cultural environments.

This problem may to some extent be explained through Hofstede's (2001, p. 297) masculinity/femininity dimension of culture where "women are assumed to be more modest, tender, and concerned with the quality of life," whereas in masculine societies like Vietnam and Mongolia "men are supposedly assertive, tough, and focused on material success." In Asian cultures, older persons and men typically have more power. Should they also possess a high level of education or experience, greater authority and influence is bestowed on them (Hwa-Froelich and Westby, 2003a.) Under such conditions, young female interviewers may then be at a distinct disadvantage when attempting to communicate with male respondents. HwaFroelich and Westby (2003b) suggest that they may need an older male to assist during interviews as different genders or age levels carry more seniority and respect in these cultures.

\section{The interview as social interaction}

Locations of interviews also play an important role. The authors conducted all except one of their Vietnamese interviews in relaxed convivial surroundings such as cafes or restaurants. A domestic coffee culture has been in existence since the

\section{Page 155}

(C) 2019 Journal of Asia Entrepreneurship and Sustainability Vol XV, Iss 1, June 2019 RossiSmith Academic Publications, Oxford/London UK, www.publicationsales.com 


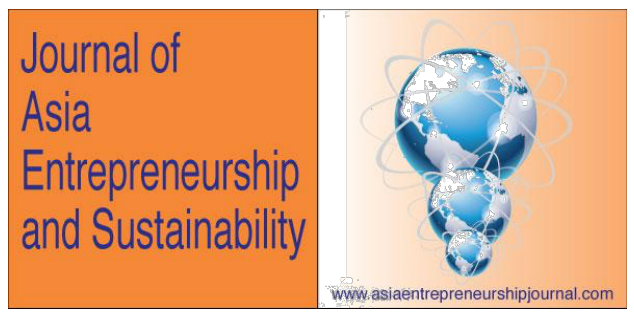

French colonialists brought it to Vietnam. It has a relaxed, non-confrontational aspect to it that facilitates frank discussion. Vietnamese like to meet in such surroundings and many business deals are brokered while drinking coffee or enjoying a meal.

Dana (2000) suggests that cultural sensitivity plays an important part in gaining buy-in from the interviewee. He describes the experience of an interviewer in a Central Asian location where the consumption of kumis (fermented mare's milk) is a traditional practice on each arrival and departure. In this region, refusal of such hospitality is perceived as extremely offensive and as such may impact on the responses received from the interviewee.

This type of cultural idiosyncrasy was also evident but very different in Mongolia where entrepreneur interviewees preferred to conduct research interviews in their offices rather than cafes. The interpreters explained that the entrepreneurs had been successful against the odds in a harsh business environment. They wanted to boast of their achievements in an effort to impress. Consequently before commencing with the interviews there was much clucking over awards and photos that adorned the walls of their premises followed by the obligatory drinking of tea or coffee along with polite conversation. On one occasion the researchers were offered a 


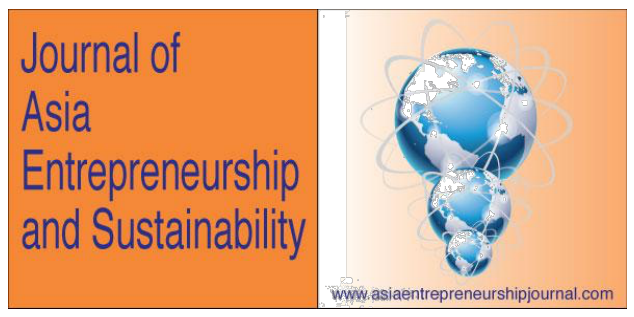

choice of tea, coffee or kumis. The researchers opted for tea but it was noted later in the post interview debrief that the 'tea' response appeared to elicit some sense of cultural offence. The interpreter pointed out that under these circumstances we probably should have responded by accepting the kumis rather than the tea. This mistake was not repeated.

According to De Santis (1980) it is the style of the interview, its purpose, and its socially defined value that all have a significant effect on the quality of the interaction between a researcher and interviewee, with the quality of data having the most impact on the outcome of the interview. Each of the parties plays a delicate and important role that is crucial in developing rapport. Interpreters should not act as either ambassadors for a researcher or the interviewees but as informational facilitators who keep the interview on track (Davidson, 2000).

\section{Some practical applications}

The following guidelines can facilitate capture of authentic and accurate interview data and will help to avoid controversy as well as manage the challenges of the cross-cultural research interview: 


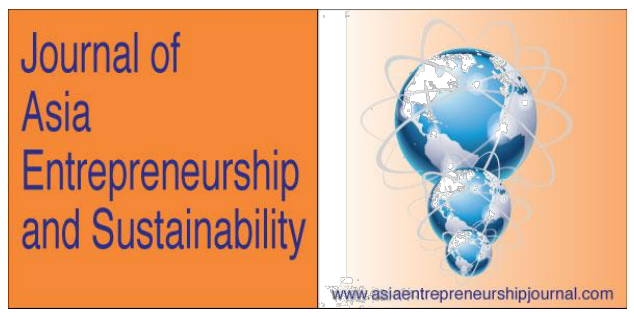

1. Do the necessary background research for an understanding of the culture, geopolitical, local, industry-specific idiosyncrasies, and cultural taboos, as well as any relevant cultural norms and culturally sensitive issues (emic traits).

2. Carefully plan what you need to know and develop strategies for obtaining this information through the interview and interpretation processes.

3. Use a laddering technique to mine for the richest data rather than accepting the first response to your questions. Ask how, when, and why whenever a deeper answer can be solicited from interviewees.

4. Build the interview structure on a theoretical framework, which in this case would be an entrepreneurship framework, but be open to the use of other theoretical explanations, which could include theory from strategy, leadership, communication, and even the sociology and psychology disciplines.

5. Use local knowledge and local people as interpreters and attempt to establish a relationship where the importance of honesty and openness are conveyed to the interviewees.

6. Prepare your interpreters so that they are informed of your objectives, have more than a passing knowledge of your interests, and can convey back to you not only what is said, but also how it is said.

\section{Page 158}

(C) 2019 Journal of Asia Entrepreneurship and Sustainability Vol XV, Iss 1, June 2019 RossiSmith Academic Publications, Oxford/London UK, www.publicationsales.com 


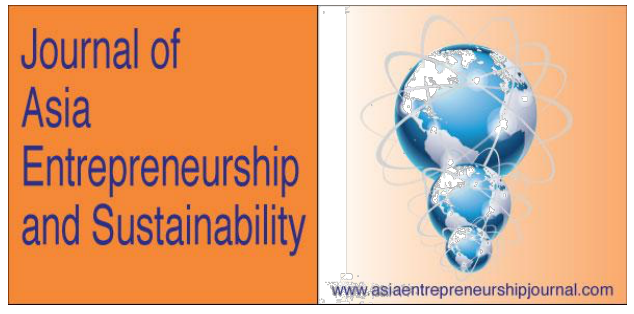

7. Where possible use a multi-method approach to verify details. Where such methods are not available, attempt to confirm your findings through further interviews or by digging deeper into interviewee responses.

8. Cooperation and trust may have to be 'purchased' through an act of reciprocity. The costs of such acts should never exceed their perceived benefits and must not have negative consequences for the collection of truthful and accurate data. Such arrangements must be negotiated or declined before commencing with the interview.

9. Involve the interpreters but do not let them manage the interviews or you may lose control over your research process.

10. Retain your interpreter for the data analysis stage. There may be a default tendency to interpret and understand data through the filters of your own ontological perspective - your values, your upbringing, your education, and the influence of prior research, as well as dealing with the effect of personal bias and memory flaws as well as potential flaws with the manner in which the interview was recorded.

11.The issue of representativeness must be established before concluding that the data speaks for many, some, or only those who were interviewed. 


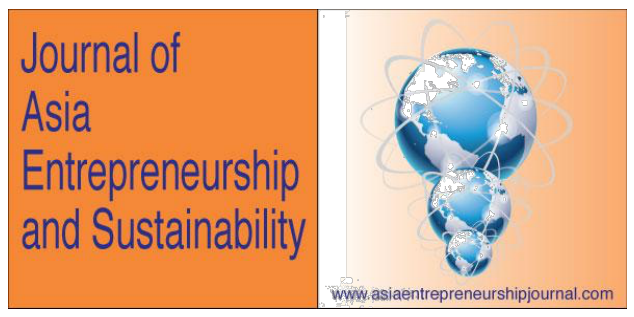

12.Clearly specify whether your research is intended to simply record responses regardless of their truth or accuracy, or whether you have attempted to seek truthful and accurate data.

13. Your research must always clearly and accurately describe the method used.

This will forestall preventable criticism by other researchers, as well as indicating possible limitations, strengths, and providing advice for further research.

\section{Conclusion}

The above points will improve the scientific rigour of cross-cultural interview research. It is argued that this is not only a necessity for reducing the element of uncertainty from the research but also a means of showing respect to those who are the object of our scrutiny.

This discussion has focused specifically upon the cross-cultural interview process as experienced with entrepreneurs in Vietnam and Mongolia. Word limitations prohibit the inclusion of more detailed discussions of our findings except to say that both cultures produced very similar entrepreneurial behaviours. These behaviours focused strongly on opportunity and problem recognition. Both Vietnam and Mongolia are developing nations characterised by inadequacies in 


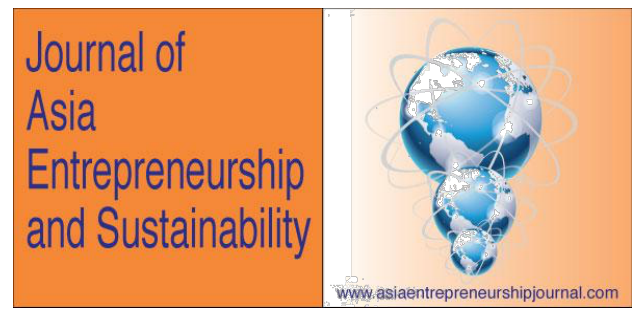

resources and infrastructure. None of those interviewed seemed critical of these deficiencies. Without exception, every interviewee saw these inadequacies simply as a problem to be solved in the most economically beneficial manner possible. Many of the interviewees modestly attributed their success not so much to their own skills and abilities, but more to the opportunities presented by the limitations and unique characteristics of their countries.

\section{Page 161}

(C) 2019 Journal of Asia Entrepreneurship and Sustainability Vol XV, Iss 1, June 2019 RossiSmith Academic Publications, Oxford/London UK, www.publicationsales.com 


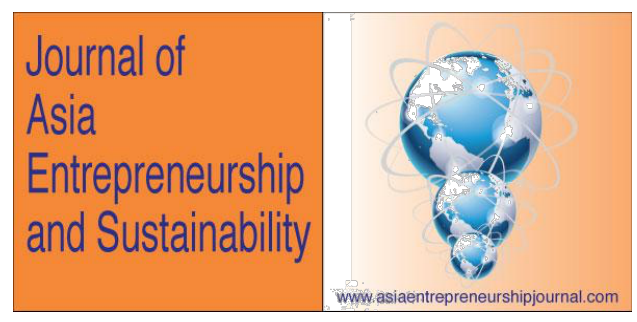

\section{References:}

Adler, N. (1983), 'Cross-cultural management research: the ostrich and the trend', Academy of Management Review. 8, pp. 226-232.

Alvesson, M. and Sköldberg, K. (2000), Reflexive methodology: New vistas for qualitative research, London, Sage.

Avery, .P.B. (2001), 'The role of the health care interpreter: An evolving dialogue', The National Council on Interpreting in Health Care: Working Papers Series, http://www.a2hc.org/articles/The\%20role_of_health_care interpreter.pdf. Accessed on $11^{\text {th }}$ May, 2010.

Avison, D.E and Wood-Harper, A.T. (1991), 'Conclusions from action research: The multiview experience', in Jackson, M.C., (Ed), Systems Thinking in Europe, New York, NY, Plenum Press.

Beals, R. and Woolfolk, A. (2006), Politics of social research, Transaction Books. Benevene, P. and Cortini, M. (2010), 'Interaction between structural capital and human capital in Italian NPOs: Leadership, organizational culture and human resource management', Journal of Intellectual Capital, 11, 2, pp. 123-139. Benney, M., Riesman, D. and Star, S. A. (1956), 'Age and sex in the interview', The American Journal of Sociology. 62, 2, pp. 143-152, http://www.jstor.org/stable/2773344, accessed on $16^{\text {th }}$ May, 2010. Berrell, M., Wright, P. and Tran, T. V. H. (1999), 'The influence of culture on managerial behaviour', Journal of Management Development. 18, 7, pp. 578-589. Bird, S., Wiles, J. L., Okalik, L., Kilabuk, J. and Egeland, G. M. (2009), 'Methodological consideration of story telling in qualitative research involving indigenous peoples', IUHPE - Global Health Promotion. 16, 4, pp. 16 - 26.

Brämberg, E. B., \& Dahlberg, K. (2013). Interpreters in Cross-Cultural Interviews: A Three-Way Coconstruction of Data. Qualitative Health Research, 23(2), 241247. 


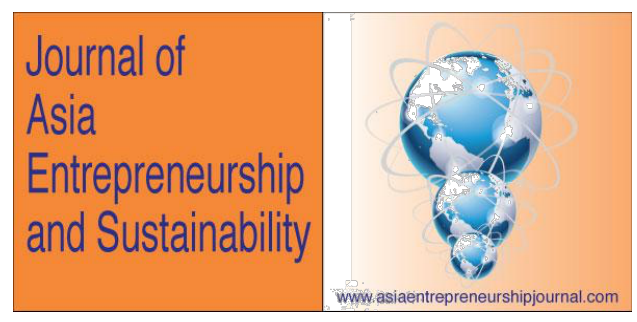

Briggs, C. L. (1986), Learning how to ask: A sociolinguistic appraisal of the role of the interview in social science research, Cambridge University Press.

Catania, J. A., Binson, D., Canchola, J., Pollack, L.M., Hauck, W. and Coates, T.J. (1996), 'Effects of interviewer gender, interviewer choice, and item wording on responses to questions concerning sexual behavior', Public Opinion Quarterly. 60, pp. 345-375.

Cavusgil, S.T. and Das, A. (1997), 'Methodology issues in cross-cultural sourcing research - a primer', Marketing Intelligence \& Planning. 15, 5, pp. 213-220. Coughlin, B.C. and Venkatesh, S.A. (2003), 'The urban street gang after 1970', Annual Review of Sociology. 29, pp. 41-64.

Crossley, M. (2000), Introducing narrative psychology, Buckingham, OU Press. Dana, L. P. (2000), 'Change and circumstance in Kyrgyz markets', Qualitative Market Research: An International Journal. 3, 2, pp. 62-73.

David, R. A. and Rhee, M. (1998), 'The impact of language as a barrier to effective health care in an underserved urban Hispanic community', Mount Sinai Journal of Medicine, October/November, 5 \& 6, 65, pp. 393-397, http://www.vdh.virginia.gov/ohpp/clasact/documents/CLASact/research3/13 Davi d.pdf, accessed on $1^{\text {st }}$ June, 2010.

Davidson, B. (2000), 'The interpreter as institutional gatekeeper: The sociallinguistic role of interpreters in Spanish-English medical discourse', Journal of Sociolinguistics. 4, 3, pp. 379-405.

De Jong, G., Tu, P.A. and Ees, H.V. (2012), 'Which entrepreneurs bribe and what do they get from it? Exploratory evidence from Vietnam', Entrepreneurship Theory \& Practice, 36, 2, pp. 323-345.

De Santis, G. (1980), 'Interviewing as social interaction', Qualitative Sociology, 2, 3, pp. $72-98$.

Escotet, M. A., (2018), 'What do we Mean for Cross Cultural Research in Psychology?', available at http://miguelescotet.com/2018/purpose-of-crosscultural-research-in-psychology/ 


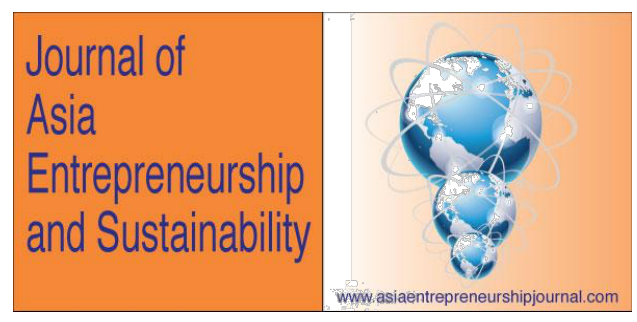

Everett, J. (2002), 'Organizational research and the praxeology of Pierre Bourdieu', Organizational Research Methods, 5, 1, pp. 56 - 80.

Farooq, S. and Fear, C. (2003), 'Working through interpreters', Advances in Psychiatric Treatment, 9, pp. 104-109.

Freeman, D. (1997), 'Paradigms in collision: Margaret Mead's mistake and what it has done to anthropology', Skeptic. 5, 3, pp. 66-73.

Friedland, D. and Penn, C. (2003), 'Conversation analysis as a technique for exploring the dynamics of a mediated interview', International Journal of Language \& Communication Disorders, $\underline{38}, \underline{1}$, pp. $95-111$. Gephart, R.P. Jr. and Richardson, J. in M.M. Harris (Ed) (2008), Handbook of research in international human resource management, New York, Lawrence Erlbaum Associates.

Giles, H., Noels, K. A., Williams, A., Ota, H., Lim, T-S., Ng, S. H., Ryan, E. B. and Somera, L. (2003), 'Intergenerational communication across cultures: Young people's perceptions of conversations with family elders, non-family elders and same-age peers', Journal of Cross-Cultural Gerontology, 18, 1, pp. 1-32. Goldstein, T. (1995), 'Interviewing in a multicultural/multilingual setting', TESOL Quarterly, 29, 3, pp. 587-593.

Hardy, C., Phillips, N., and Clegg, S. (2001), 'Reflexivity in organization and management theory', Human Relations, 54, 5, pp. 531-60.

Harkess, S. and Warren, C.A.B. (1993), 'The social relations of intensive interviewing: Constellations of strangeness and science', Sociological Methods \& Research. 21, 3, pp. 317-339.

Herdman, M., Fox-Rushby, J., and Badia, X. (1998), 'A model of equivalence in the cultural adaptation of HRQoL instruments: The universalist approach', Quality of Life Research, 7, pp. 323-335, as cited in S. Sidani, S. Guruge, J. Miranda, M. Ford-Gilboe, and C. Varcoe, (2010), 'Cultural adaptation and translation of measures: An integrated method', Research in Nursing \& Health, 33, pp. 133-143. 


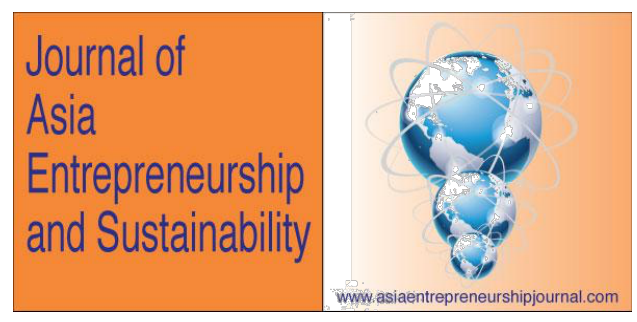

Hobbs, S., Anderson, S. and McKechnie, J. (2009), 'Exploring risks faced by child workers in Britain', International Journal of Sociology and Social Policy. 29, 3/4, pp. 176-185.

Hofstede, G. (2001), 'Culture's consequences: Comparing values, behaviors, institutions, and organizations across nations', 2nd ed. BeverlyHills, CA. Sage Publications.

Holloway, I. (2005), Qualitative research in health care, Open University Press. McGraw - Hill Education.

Holstein, J. A. and Gubrium, J.F. (1995), The active interview, Sage Publications. Holstein, J. A. and Gubrium, J. F. (2003), Inside interviewing: New lenses, new concerns, Sage Publications.

Hughes-Scholes, C. H. and Powell, M. B. (2008), 'An examination of the types of leading questions used by investigative interviewers of children', Policing: An International Journal of Police Strategies \& Management, 31, 2, pp. 210 - 225. Hussain, J.G., Scott, J.M., Harrison, R.T. and Millman, C. (2010), 'Enter the dragoness: Firm growth, finance, guanxi, and gender in China', Gender in Management: An International Journal, 25, 2, pp. 137-156.

Huxham, C. and Vangen, S. (2003), 'Researching organizational practice through action research: Case studies and design choices', Organizational Research Methods, 6, 3, pp. $383-404$.

Hwa-Froelich, D. A. and Westby, C. E. (2003a), 'A Vietnamese head start interpreter: A case study', Communication Disorders Quarterly, Winter, 24, 2, p. 86.

Hwa-Froelich, D. A. and Westby, C. E. (2003b), 'Considerations when working with interpreters', Communication Disorders Quarterly, Winter, 24, 2, p. 78. Javier, R. A. (2007), The bilingual mind: Thinking, feeling and speaking in two languages, series: Cognition and language: A series in psycholinguistics, $\mathrm{New}$ York, Springer. 


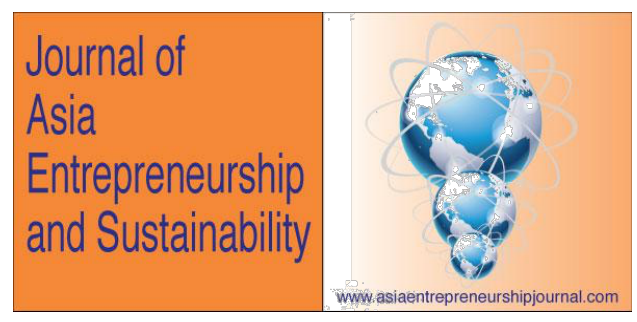

Jaya, Hindin, M. J. and Saifuddin, A. (2008), 'Differences in young people's reports of sexual behaviors according to interview methodology: A randomized trial in India', American Journal of Public Health. 98, 1, pp. 169 - 175.

Jentsch, B. (1998), 'The 'Interpreter Effect': Rendering interpreters visible in crosscultural research and methodology', Journal of European Social Policy, 8, p. 275. Kane, E.W. and Macaulay, L.J. (1993), 'Interviewer gender and gender attitudes', Public Opinion Quarterly, 57, pp. 1-28.

Kaufert, J. M. and Koolage, W. K. (1984), 'Role conflict among 'culture brokers': The experience of native Canadian medical interpreters', Social Science \& Medicine. 18, 3, pp. 283-286.

Keeley, L.H. (1996), War before civilization, Oxford University Press.

Kemmis, S. (1985), 'Action research and the politics of reflection', In: D. Boude et al (1985), Reflection: Turning experience into learning, London. Kogan Page.

Kluckhohn, C. (1954), 'Culture and behaviour', in T. S. Kuhn (Ed.) (1962), Handbook of social psychology, The structure of scientific revolutions, Chicago, Illinois, University of Chicago Press.

Kong, L. (1998), 'Refocusing on qualitative methods: Problems and prospects for research in a specific Asian context', Area, 30, 1, pp. 79-82.

Kreiser, P.M., Marino, L.D., and Weaver, K.M. (2002), 'Assessing the psychometric properties of the Entrepreneurial Orientation Scale: A multi-country analysis', Entrepreneurship Theory \& Practice, summer, pp. 71-94.

Kuhn, T.S. (1962), The structure of scientific revolutions, University of Chicago Press.

Laverack, G. R. and Brown, K. M. (2003), 'Qualitative research in a cross-cultural context: Fijian experiences', Qualitative Health Research, 13, p. 333. 


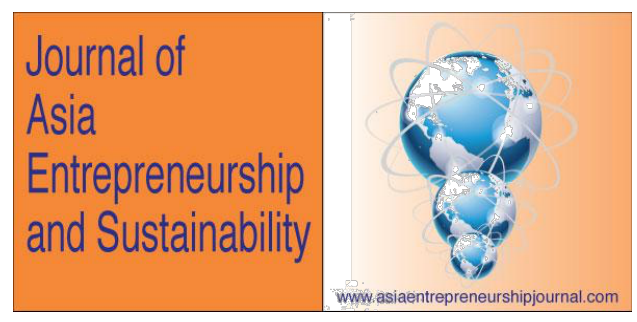

Leshkowich, A.M. (2006), 'Woman, Buddhist, entrepreneur: Gender, moral values, and class anxiety in late socialist Vietnam', Journal of Vietnamese Studies. 1, 1-2, pp. 277-313.

Lévi-Strauss, C. (1963), Totemism, Beacon Press, Boston.

Lim, F. K. G. (2010), 'Southeast Asian lives: Personal narratives and historical experience (review)', Sojourn: Journal of Social Issues in Southeast Asia, 25, 1, pp. 133-138.

Lincoln, M. (2008), 'Report from the field: Street vendors and the informal sector in Hanoi', Dialectical Anthropology, 32, 3, pp. 261-265.

Locander, W., Sudman, S. and Bradburn, N. (1976), 'An investigation of interview method, threat and response distortion', Journal of the American Statistical Association. 71, 354, pp. 269-275.

Luo, Y. (2002), 'Building trust in cross-cultural collaborations: Toward a contingency perspective', Journal of Management. 28, pp. 669 - 694.

McCaffrey, A. (2000), 'Don't get lost in translation: Teaching law students to work with language interpreters', Clinical Law Review, 6, pp. 347 - 399.

Maurer, S. D. (2002), 'A practitioner-based analysis of interviewer job expertise and scale format as contextual factors in situational interviews', $\underline{\text { Personnel }}$ Psychology, 55, 2, pp. 307- 328.

Meuter R. F., Gallois, C., Segalowitz, N. S., Ryder, A. G., Hocking, J., (2015), 'Overcoming language barriers in healthcare: A protocol for investigating safe and effective communication when patients or clinicians use a second language', $B M C$ Health Services Research Journal. 15:371, Sep 10. doi:10.1186/s12913-015-10248 


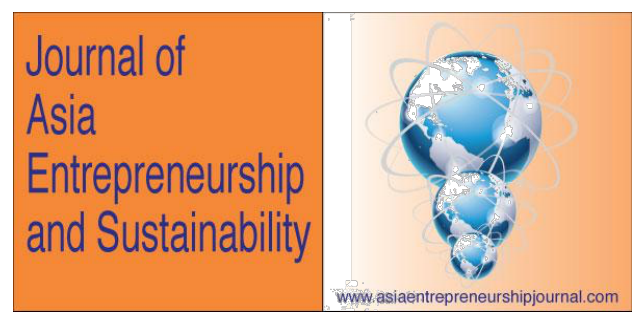

Napier, N. K., Hosley, S. and Nguyen, T.V. (2004), 'Conducting qualitative research in Vietnam: Ethnography, grounded theory and case study research', in R. Marschan-Piekkari, and C. Welch, (Eds.), (2004). Handbook of qualitative research methods for international business, Edward Elgar Publishing. Nobel, G. (2005), 'The discomfort of strangers: Racism, incivility and ontological security in a relaxed and comfortable nation', Journal of Intercultural Studies. 26, 1 \& 2, pp. $107-120$.

Pech, R.J. (2009), Entrepreneurial courage, audacity, and genius, Sydney, Australia, Pearson Education.

Phongpaichit, P. (1999), 'Cultural factors that shape governance in South East Asia, Essay written for UNESCO, pioneer.netserv.chula.ac.th/ ppasuk/culturalgovernance.doc, accessed on $20^{\text {th }}$ November, 2009.

Piekkari, R. and Welch, C., Eds., (2005), Handbook of qualitative research methods for international business, Edward Elgar Publishing. Pistillo, G. (2003-2004), 'The interpreter as cultural mediator', Journal of Intercultural Communication. 6. http://www.immi.se/intercultural/nr6/pistillo.htm, accessed on $7^{\text {th }}$ May, 2010.

Pitchforth, E. and van Teijlingen, E. (2005), 'International public health research involving interpreters: A case study from Bangladesh', BMC Public Health. 5, pp. $1-7$.

Robinson, O. C., (2014), Sampling in Interview-Based Qualitative Research: A Theoretical and Practical Guide, Qualitative Research in Psychology, 11:1, 2541, DOI: $\underline{10.1080 / 14780887.2013 .801543}$

Schwerdtfeger, K. (2009), 'The appraisal of quantitative and qualitative traumafocused research procedures among pregnant participants', Journal of Empirical Research on Human Research Ethics, 4, 4, pp. 39-51. 


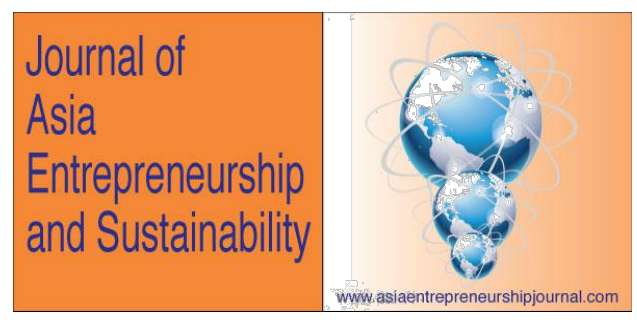

Scott, S., Miller, F. and Lloyd, K. (2005), 'Doing fieldwork in development geography: Research culture and research spaces in Vietnam', Geographical Research, 44, 1, pp. 28 - 40.

Searle, J.R. (1995), The construction of social reality, London, Penguin Press. Shazia, J., (2014), "Qualitative research method-interviewing and observation" Journal of basic and clinical pharmacy vol. 5,4 (2014): 87-8. Shermer, M. (2005), Science friction: Where the known meets the unknown, New York, Times Books.

Smith, J. N. (2006), 'Research report: Maintaining margins: The politics of ethnographic fieldwork in Chinese Central Asia', The China Journal, 56, pp. 131147.

Soin, K. and Scheytt, T. (2006), 'Making the case for narrative methods in crosscultural organizational research', Organizational Research Methods, 9, 1, pp. 5577.

Soucy, A. (2000), 'The problem with key informants', Anthropological Forum, 10, 2, pp. 179-199.

Stewart, D. W. and Shamdasani, P. N. (1990), Focus groups: Theory and practice, London, Sage.

Suzuki, L. A., Ahluwalia, M. K., Mattis, J. S. and Quizon, C. A. (2005), 'Ethnography in counseling psychology research: Possibilities for application', Journal of Counselling Psychology, 52, 2, pp. 206-214.

Taleb, N.N. (2006), 'You Can't Predict Life's Black Swans', New Scientist, 1 July, pp. 50-51.

Talib, M. A. (2010), 'Cultural influences and mandated counselling in Malaysia', Asian Culture and History, 2, 1, pp. 28 - 34. 


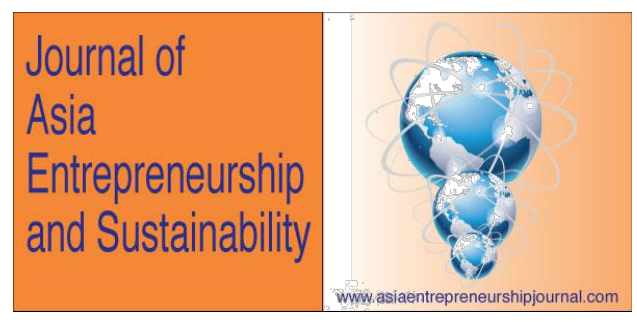

Temple, B. and Edwards, R. (2002), 'Interpreters/translators and cross-language research: Reflexivity and border crossings', International Journal of Qualitative Methods, 1, 2, http://www.ualberta.ca/ iiqm/backissues/1_2Final/html/temple.html, accessed $6^{\text {th }}$ June 2010.

Thai, M.T.T. (2010), 'The influences of Vietnam's administrative reform on entrepreneurial orientation in micro enterprises, The Business Review, Cambridge, 15, 2, pp. 110-116.

Tuang, A. and Stringer, C. (2008), 'Trust and commitment in Vietnam: The industrial distributor's perspective', International Journal of Emerging Markets, 3, 4, pp. 390-406.

Turner, M. (2010), An Investigation into Entrepreneurship in the Transition Economies of Vietnam and Mongolia and the Complexities of Conducting Research in Culturally Different Countries, $\mathrm{PhD}$ thesis, La Trobe University, Melbourne, Australia. van Rekom, J., van Riel, C.B. and Wierenga, B. (2006), 'A methodology for assessing organizational core values', Journal of Management Studies, 43, 2, pp. 175-201.

Veal, A.J. (2005), Business research methods: A managerial approach, Pearson, Frenchs Forest, NSW, Australia.

Wade, N. (2006), Before the dawn: Recovering the lost history of our ancestors, New York, Penguin Press.

Wallin, A.M. and Ahlstrom, G. (2006), 'Cross-cultural interview studies using interpreters: systematic literature review', Journal of Advanced Nursing, 55, 6, pp. 723-735.

Wallin, A.M. (2007), 'Diabetes: A cross-cultural interview study of immigrants from Somalia', Journal of Clinical Nursing, 16,11c, pp. $305-314$. 


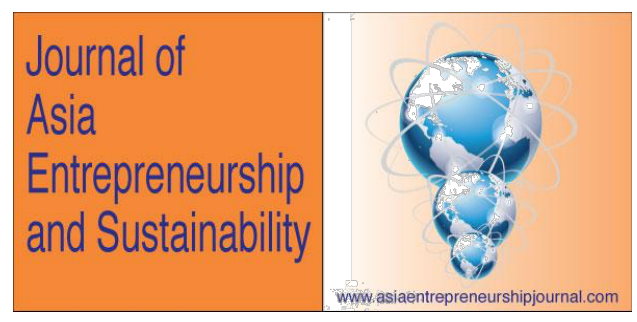

Welch, C. and Piekkari, R. (2006), 'Crossing language boundaries: Qualitative interviewing in international business', Management International Review, 46, 4, pp. 417-437.

Westermeyer, J. and Janca, A. (1997), 'Language, culture and psychopathology: Conceptual and methodological issues', Transcultural Psychiatry, 34, 3, pp. 291311.

Witzel, A. (2000), 'The problem-centered interview', Forum QualitativeSozialforschung / Forum: Qualitative Social Research, 1(1), Art. 22, http://nbnresolving de/urn:nbn:de:0114-fqs0001228, accessed 5th June, 2010

Whiteford, G. E. and McAllister, L. (2006), 'Politics and complexity in intercultural fieldwork: The Vietnam experience', Australian Occupational Therapy Journal, 54, 1, pp. 74 - 83.

Wright, P.C. and Nguyen, V.T. (2000), 'State-owned enterprises (SOEs) in Vietnam - Perceptions of strategic direction for a society in transition', International Journal of Public Sector Management', 13, 2, pp. 169-177. Yin, R. (2003), 'Case study research: Design and methods', $3^{\text {rd }}$ ed., Thousand Oaks, California, Sage Publications.

Young, J.C., Rose, D. C., Mumby, H.S., et al., (2018), 'A methodological guide to using and reporting on interviews in conservation science research'. Methods Ecol Evol., 9:10-19. Available at https://doi.org/10.1111/2041-210X.12828

Zikmund, W., Babin, Carr, J. and Griffin, M. (2010), Business research methods, $8^{\text {th }}$ ed., Mason OH, South-Western CENGAGE Learning. 


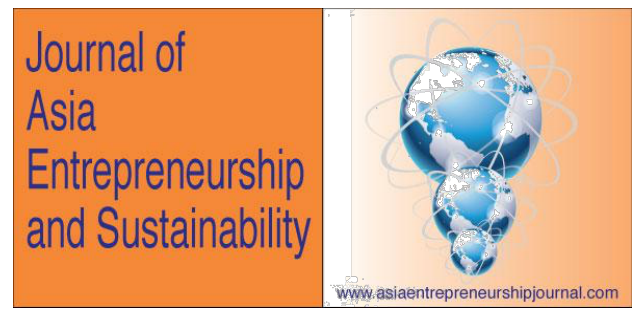

\title{
The Effect of Religiosity, Spirituality and Family Power Influence on Family Business Sustainable Values
}

\author{
Zazli Lily Wisker \\ Marketing Department \\ Pacific International Hotel Management School \\ 4 Henwood Road, Bell Block, New Plymouth, New Zealand \\ lilyw@pihms.ac.nz \\ Vikinta Rosinaite \\ Liberal Arts Department \\ American University of the Middle East, Kuwait \\ Balakrishnan Muniapan \\ School of Business and Administration, Wawasan Open University, Malaysia
}

\begin{abstract}
Family businesses are distinct from non-family businesses due to the families' involvement in managing and influencing the business. The influence can take several forms. This study examines if religiosity, spirituality and power influence

Page 172

(C) 2019 Journal of Asia Entrepreneurship and Sustainability Vol XV, Iss 1, June 2019

RossiSmith Academic Publications, Oxford/London UK, www.publicationsales.com
\end{abstract}




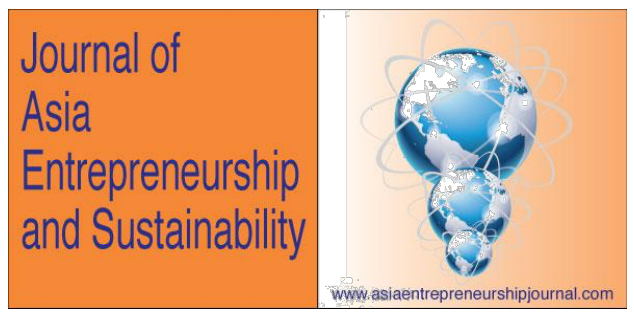

of the owning family business affect the family businesses' corporate social responsibility towards their customers, employees, shareholders and societies. The study hypothesises positive effects of religious belief, religious practice, spirituality and power influences on family business corporate social responsibility. Data was collected among 251 family members from 84 small to medium-sized family businesses in the North Island of New Zealand. The relationships were significant for spirituality and religious practice (negative effect). Ultimately, discussion and practical implications are discussed.

\section{Introduction}

Family businesses represent key contributors to many countries' economies worldwide (Senegovic et al., 2015). According to the Family Enterprise Research Academy (2015), family businesses represent $80 \%$ to $95 \%$ of all private companies worldwide. They contribute to new job creation and sustain the business beyond two and three family generations (Ramadi and Hoy, 2015). Given the importance of family businesses to the global economy, the study of ethics on these businesses is undoubtedly significant (Vazquez, 2018). Family businesses are fundamentally different from non-family businesses (Chrisman, Chua and Sharma, 2005; Sharma and Sharma, 2011). More exclusively, the literature has acknowledged the differences in embracing business ethics and values between family businesses and 


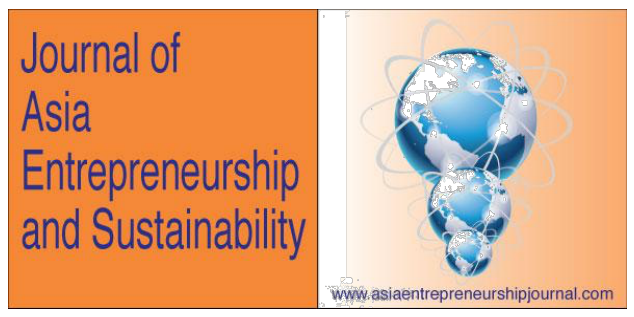

non-family businesses (Yazici, McWilliams and Erca, 2018). In family businesses, the values are often imposed by the beliefs and values of the owning family. Indeed, Sorenson (2013) has observed that a family owning a business often transfers their beliefs and values to shape the business organisational structure and system. This is because family businesses are often managed by a dominant coalition (Sharma and Sharma, 2011). The dominant comes from the founder, family members who work in the business, and employees hired through nepotism (Chua, Chrisman and Sharma, 1999). On the positive side, the studies have found that family businesses tend to be more socially responsible than non-family businesses because they want to build a positive reputation in society and to enhance their family reputation image (Dyer and Whetten, 2006; Godfrey, 2005). The ethical practice in a family business is often influenced by the owning family and the founder through the involvement of the owning family, inclination to socio-emotional wealth, and social interaction (Vazquez, 2018). This is not surprising, as a family often combines closeness and individual authenticity (Huisman, 2014) with a strong sense of belonging and loyalty to the birth family (Ellingsen, Stephens and Storksen, 2012). Family businesses can sometimes to forgo economic wealth in order to sustain the business for a longer period of time (Sharma and Sharma, 2011). 


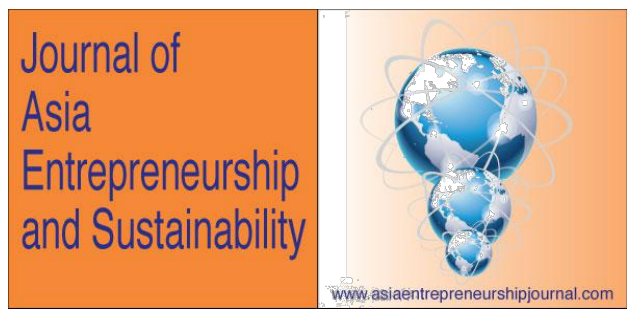

Research on spirituality and religiosity has been widely studied for decades in psychology, health science, human resource management, and marketing. Studies include the effect of spirituality and religiosity on health science and phycology (Delaney, 2005), on decision-making (Anathram and Chan, 2016) spirituality and marketing (Ali,2005), religiosity and work ethics (Wisker and Rosinaite, 2016) and religiosity and attitudes towards co-workers (Bazeman and Murdock, 2007), religiosity and economic growth (Campante and Yanagizawa-Drott (2015), among others. Nonetheless, the study on the effect of spirituality and religious values on family businesses' systems is scarce and underdeveloped (Vazquez, 2018). The question also remains if the family business's ethical values and beliefs are guided by the religiosity and spiritually that the owning family and the founder embrace. If so, how do these values and beliefs affect the organisational system of the family business? The broad aim of this paper is to evaluate the effects of religious values and spirituality on a family business's sustainable ethical value and power influence. Our study makes three contributions to the family business literature. First, our study aims to fill the gap as identified by Vazquez (2018) that the study on family business spirituality and religiosity and its effect on the business system is scarce. Second, as observed by Kellermanns (2013), family business values may be influenced by the level of spirituality and religious beliefs of the owning family. We expand this knowledge by empirically testing the effects of religiosity, 


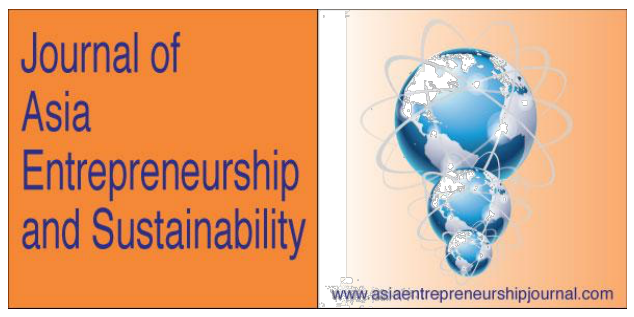

spirituality and power influence of the owning family and partners on the company's business values towards their customers, employees, stakeholders, and society. We believe the relationship among the owning family's religious beliefs and spirituality and business values in family business is positive. Our notion is supported by the studies that family businesses are often governed and controlled by the dominant owning family, hence the family business possess cultural features such as expression of spirituality and religious values more than non-family business (Paterson et al., 2013; Rao et al., 2018). Third, as observed by Durendez and Madrid-Guijarro (2018), family influences on the family business tends to differ based on the structural differences off the business (whether it is small to medium -sized or private versus public listed), our study contributes to the literature by examining private small to medium-sized family businesses.

\section{Framework}

We define a family business "as a company governed and/or manage by a family or a small group of families to pursue the vision of the business and to be sustainable across generations" (Chua, Chrisman and Sharma, 1999, p. 25). Accordingly, the family business consists of either family members or a combination of family and non-family who are recruited by the controlling family. This would translate into a strong influence of the family on the non-family 


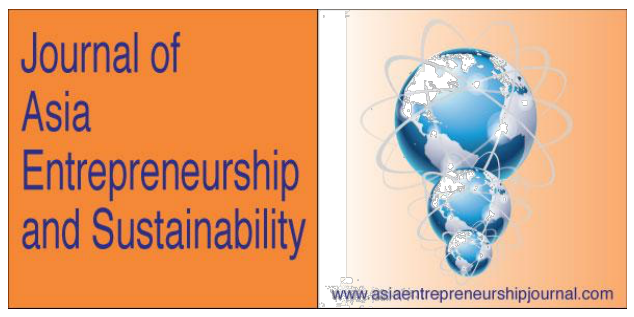

employees. Sharma and Chua (2013) have elaborated the concept of family members in a family business. All in all, family members in a family business involvement include relationships by blood, marriage, adoption, nuclear family, extended, blended, and other family structures such as cohabiting couples (Sharma and Chua, 2013). Honouring this concept, we have excluded single-owner businesses as the subject of our study. We do this simply to minimise the skew of the results.

We base our conceptual model on the F-PEC scale family business theory developed by Astrachan et al. (2002) that suggested in a family business, the business is often influenced by the family power domains, family members' experiences and also family's culture. Translating this to a family business that practices sustainability, the spirituality and religious values of the owning family should influence the company's intention to behave ethically towards corporate social responsibility as defined by its customers, employees, stakeholders, and society. Additionally, the family power domain as defined by the percentage of members sitting on the board and senior management position would increase the influence on the business processes and systems. 


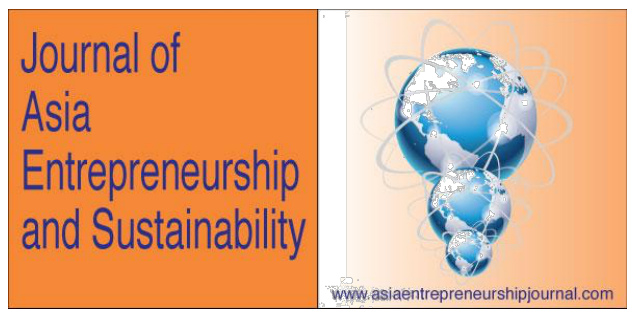

\section{Spirituality}

Although spirituality has its roots in religion, the spirituality literature has conceptualised it somewhat differently from religion (Burkhardt and NagaiJacobson, 2002; Delaney, 2005; Dyson, Cobb and Forman, 1997). Religion arguably has a narrower conception of organisational system of belief; in contrast, the concept of spiritually is broader and encompasses multiple dimensions. The concept of spirituality represents a more holistic approach and the personal values of oneself towards others and the environment (Fox, Webster and Casper, 2018). In studying the literature, we found that the concept of spirituality is consistently held to have three dimensions: self- discovery or self-awareness, relationships with others, and connection with the environment or eco-awareness (Delaney, 2005; Fox et al, 2018; Giacalone and Jurkiewicz, 2003). The early spirituality scholar Frankl (1959) has suggested that the major problem of society in the $21^{\text {st }}$ century is that society has lacked knowledge of meaning in life, which he termed an existential vacuum. Frankl's (1959) argument is echoed by several others such as Rozuel and Kakabadse (2010) and Vice (2003), who argue that human beings are complex individuals, are often affected by conflicting drivers, or might not have good sense of direction, resulting to follow a different moral code inside the workplace from that of everyday life. 


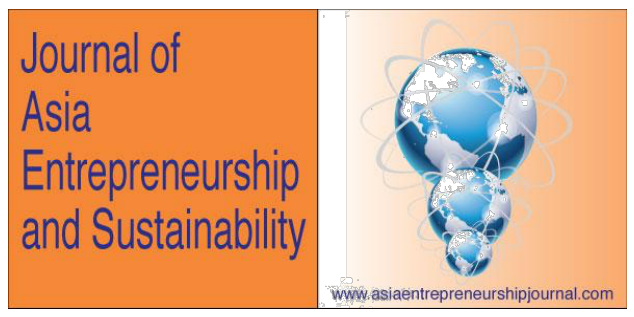

Spirituality is the highest form of human potential and involves a search for unity, connectedness, and transcendence (Pargament, 1999). Spirituality is also argued to orient one's life towards something nonmaterial beyond oneself, as well as acknowledging some dependence upon a higher power or spirit (Martin and Carlson, 1998). It encompasses the relationship with the universe or cosmos that brings a feeling of connectedness, sense of satisfaction with the self, others, and the universe without having to compromise one's values (Layder 2004). Spohn (1997) suggests spirituality as being either "lived spiritualities" or "reflective spiritualities". Whilst lived spiritualities manifest in everyday life, interpretation and communication of experience constitutes reflective spirituality.

\section{Religiosity}

Although the definition of religiosity varies (Ferm, 1963; King, 2007; Weber, 1958), and some consider it to be lacking (Barnet, Bass and Brown, 1996), religiosity has often been associated with religious cognition in terms of knowledge, beliefs, values, and emotional attachmenst such as affiliation with a particular house of God, reading (scripture), and praying (Cornwall et al., 1986; Roccas et al., 2002) that resulted in a set of behaviour and meanings which are often ascribed to religious people (Ferm, 1963). King (2007) defines religion as a "set of beliefs, feelings, dogmas and practices that provides an ethical and moral 


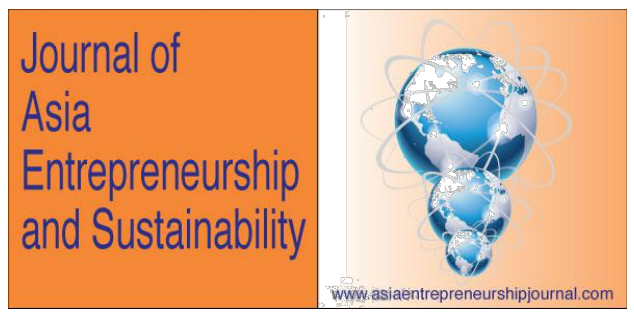

framework for understanding, motivation, and behaviour" (p. 104). A given religion is defined by the material and practices of its community of adherents: dogma, sacred books, rites, worship, sacrament, moral prescriptions, interdicts, and organizations (Johnson et al., 2001). In this study we have classified religiosity as having two dimensions: religious practice and religious belief (Lewis and Kasyap, 2013). We note that this definition also puts us in line with Chowdhury (2018), who classifies religiosity as intrinsic (religious beliefs) or extrinsic (religious practice). Religious belief is about believing in God and the need to be affiliated with certain religion beliefs, while religious practice is about worshiping and rituals such as daily prayer, attending weekly services, and reading scriptures. The literature argues that religion is a crux of most cultural values (Ferm, 1963; Weber, 1958). This is perhaps not a new discovery, as almost all religions call for fairness, truthfulness, and trusteeship, and a broad conceptualisation of the brotherhood of stakeholders, to speak in corporate terms. For example, "Love one another as I (God) have loved you” (Bible, John, 14:24), "Give full measure when you measure out and weigh with a fair balance. This is fair and better in the end" (Qur'an 17:35), "The universe is built on kindness" (Torah 89: 3). The other values worth mentioning are the concepts of simplicity and moderation called for by most religions, which are the roots supporting corporate social responsibility. "One should abstain from acquisitiveness" (Acarangasutra, 2:119), "You cannot be slave 


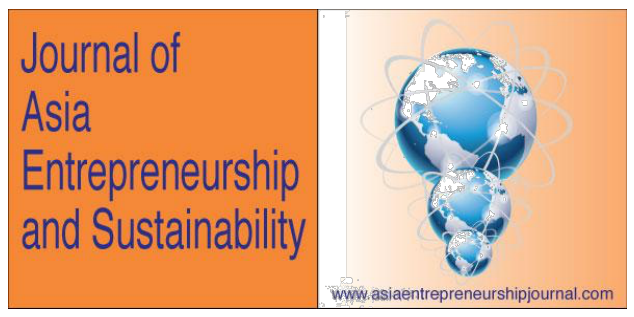

of both God and money" (Matthew 6:24) and "Eat and drink but waste to access" (Quran 7:31). Given these religious values regardless of the different faiths, one would expect these values to implicate the practice of social corporate responsibility at workplaces.

\section{Family Power Influence}

The early theory of power dimension in family businesses was established by Astrachan et al. (2002). Astrachan et al. (2002) conceptualised power influence in a family business as having three dimensions; the percentage of ownership, percentage of family members on the governance board and finally the percentage of member members holding a senior managerial role. The family business literature has established that family businesses are distinct from non-family businesses because family involvement influences the way business systems and policies are managed (Rau et al., 2018, Klein et al., 2005; Sharma and Sharma, 2011). The family businesses are different from non-family business due to the commitment and the contribution of each family member who work in the business resulted to improved competitive advantage (Discua Cruz et al., 2012). Sharma and Sharma (2011) argue for the lack of a significant relationship between managerial values/beliefs and strategies among family businesses reported in some studies because previous research ignores family control as the variable in the relationship 


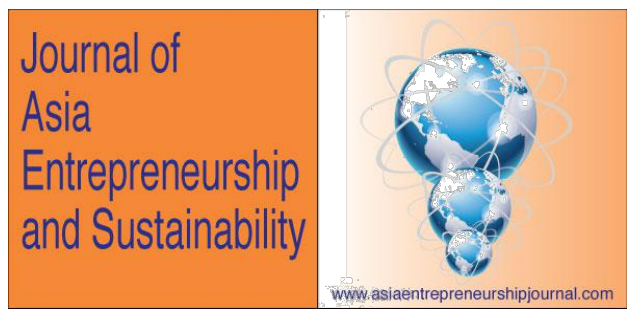

model. They conclude that family businesses are unique because (1) the members can influence decision-making in the business through its dominance and its involvement in ownership and/or management of the organisation, (2) the businesses are likely to act in a particular manner when the business vision is for the longer term, to retain family control, are more likely to substitute economic wealth for socio-emotional wealth, (3) family involvement contributes to the building of competitive advantage and social capital, and (4) family involvement can also be dysfunctional to the business due to its complexity and conflicts. Rau et al. (2018) suggest that family influence can be wielded on three levels: (1) individual level through skills, experience, and psychological ownership, (2) group level through board diversity, qualification, and interaction between families, and (3) organisational level through governance structures and laws. Ownership of the business allows family members to control the values and beliefs that become widespread within the family business and is done via long interaction and continued involvement of junior generations in the identification and pursuit opportunities (Cruz et al., 2012). To sum up, the literature has acknowledged that family members do indeed influence the processes and systems of the family businesses. 


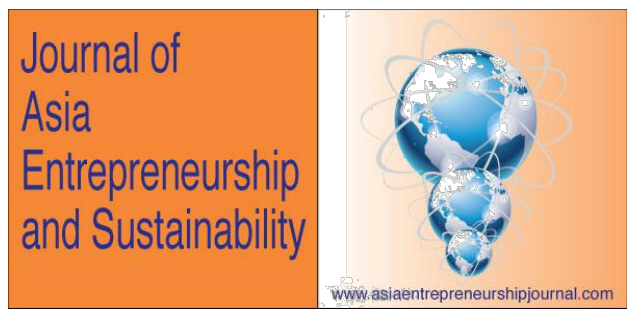

\section{Dependent Variable - Corporate Social Responsibility}

In this study, we define corporate social responsibility (CSR) as "the contextspecific organisational actions and policies that take into account stakeholders' expectation and triple bottom line in economic, social, and environmental performance" (Aguinis, 2011, p. 855). In analysing 37 definitions of corporate social responsibility, Dahlsrud (2008) observed that 88 percent of the domain concerns interaction with stakeholders such as employees, suppliers, customers, and communities. Consistent with the literature, we are especially interested to measure family business corporate social values towards its employees, customers, stakeholders (shareholders), and society in terms of commitment to environmental orientation and society at large. We use Perez and del Bosque's (2013) scale to measure corporate social responsibility.

\section{Spirituality and Corporate Social Responsibility}

The linkage between spirituality and work ethics has been documented for decades (Driscoll and McKee, 2007; Giacalone and Jurkiewicz, 2003; Issa and Pick, 2010; 2011; Wisker and Rosinaite, 2016). For example, spirituality has been observed as the driver to seek for deeper meaning in life through the way an individual works and lives (Giacalone and Jurkiewicz, 2003), as a means to boost productivity and performance at work (Karac-Kakabadse et al., 2002), as a motivator to engage in

\section{Page 183}

(C) 2019 Journal of Asia Entrepreneurship and Sustainability Vol XV, Iss 1, June 2019 RossiSmith Academic Publications, Oxford/London UK, www.publicationsales.com 


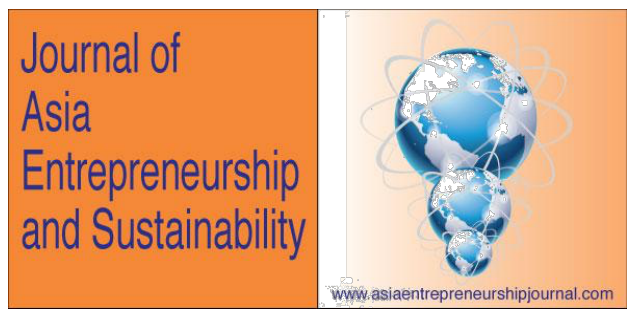

conspicuous consumption (Stillman et al., 2012) and an influence on job satisfaction and career success (Sengupta, 2010). At the corporate level, managers' spirituality has been seen to enhance relationships with employees, resulting in improved organizational performance through a meaningful work-life balance, employees' well-being, and a sense of interconnectedness between managers and employees (Karakas, 2010). Managers who have high level of spirituality can also influence ethical thinking, attitude and behaviour of employees as they understand the sense of personal values and connectedness (Driscoll and McKee, 2007). Other studies that have linked spirituality and employee performance include Ashmos and Duchon (2000), Garcia-Zamor (2003), Giacalne and Jukiewicz (2003), and Fox et al. (2018). It is worth noting, however, that the effect of spirituality at work is not always rosy. Ayoun, Rowe and Yassine (2015) found no correlation between the level of spirituality and ethical perception, ethical judgement, or moral intensity. Nonetheless, our argument supports the earlier studies; hence, we hypothesise the following:

H1 - Spirituality of the owning family positively affects the family business's sustainable values. 


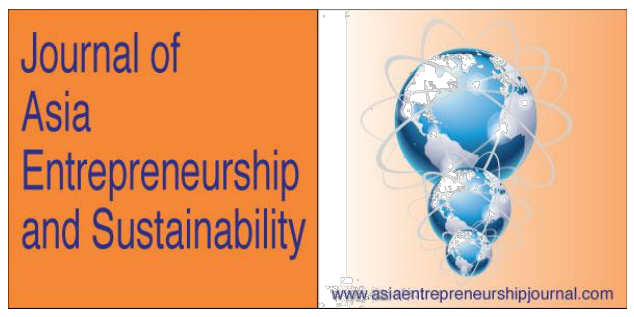

Family Business Religiosity, Power Influence and Corporate Social Responsibility The early work of the Christian Protestant Weber (1958) on work ethics has a long discussion of religion and its influences on attitude, behaviour, and individuals' work ethics. At the micro-level, religion has been inevitably linked to many aspects of human life, including personality (Ali, 2005; Wisker and Rosinaite, 2016), wellbeing (Chowdhury, 2018), behaviour towards working hard and the need for recognition (Elci, 2007), attitudes towards society and the environment (Yang and Hung, 2018), and productivity (Heaven and Ciarrochi, 2007; Saroglou, 2002). Others have established that religious values correlate positively with positive traits such as morality (Stankov and Lee, 2016), kindness, compassion, forgiveness (Heaven \& Ciarrochi, 2007), and simplicity (Chowdhury, 2018). At the corporate level, religious values have been observed as keys to practise ethics, handle a variety of business issues, and define success (Paterson et al., 2013). Indeed, Brammer, Williams, and Zinkin (2007) have observed that religion plays a significant role in shaping individual perceptions of corporate social responsibility. The effect of religiosity on corporate social responsibility spans from attitudes towards business growth and entrepreneurship (Audretsch, Boente and Tamvada, 2007), employees (Bozeman and Murduck, 2007), customers, and society (Brammer et al., 2007). Others have also found that religious practice is associated with economic outcomes and growth (Campante and Yannagizawa-Drott, 2015) 


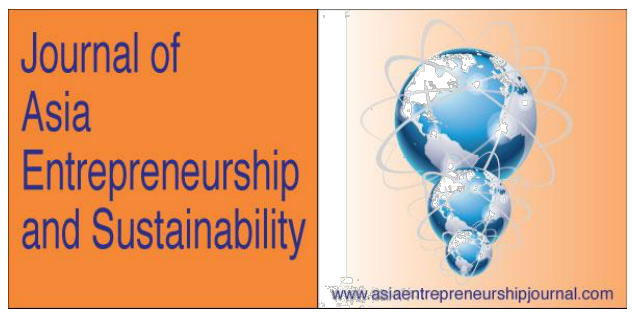

and human capital accumulation (Becker and Woessmann, 2009). In the family business literature, Bhasi, Renuka and Rajkumar (2017) studied 151 businessowning families in Kerala, India and observed how religion has influenced the family-owning business in terms of succession and inheritance.

Discussing the concept of religiosity thus far, we argue that religious beliefs and practice could influence corporations and businesses to act ethically. If religion is a value that guides one's ethical and moral values in understanding right and wrong (King, 2007), it is fair to argue that religious belief and practice of the owning family affect the family business systems and values in terms of corporate social responsibility. Hence, the following hypotheses:

$\mathrm{H} 2$ - Religious belief of the owning family positively affects the family business's sustainable values.

H3 - Religious practice of the owning family positively affects the family business's sustainable value.

\section{Family Power Influence and Sustainability}

The family business can be influenced by the number of family members working in the business and also the number of family members on the board, the bigger the 


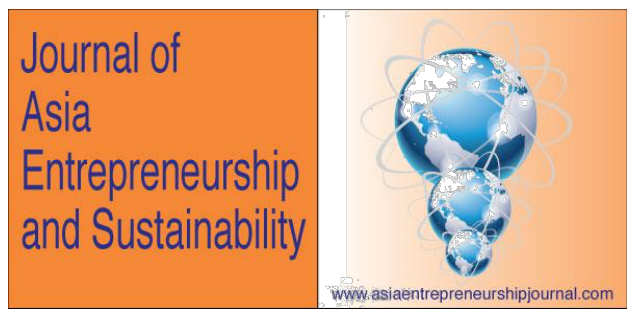

influence, the bigger the effect would be on systems and policies (Astrachan et al., 2002). Several empirical studies that examined the relationship between family power dimension and its system and processes have found positive effects. For example, Jara Bertin and Lopez. (2014) conducted a study on Spanish family businesses and found the power structure in family business is a critical factor in developing its system and processes such as the policies towards their investment. Ghosh and Tang (2015) observed positive results between family business ownerships and financial reporting. Similarly, Durendez and Madrid-Guijarro that studied 252 small and medium sized Spanish family found the relationship between family power and the way they established process and system in reporting their financial statements. Given the discussion thus far, we argue there is a positive relationship between family power influence and the practice of corporate social responsibility towards their employees, stakeholders, customers and society.

Therefore, we posit the following hypothesis;

H4 - Power influence of the owning family positively affects family business's sustainable values. 


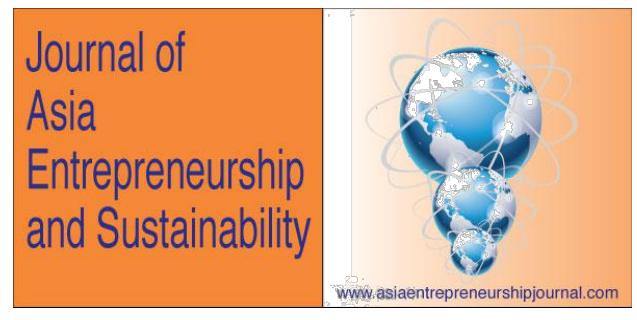

Fig 1: Framework

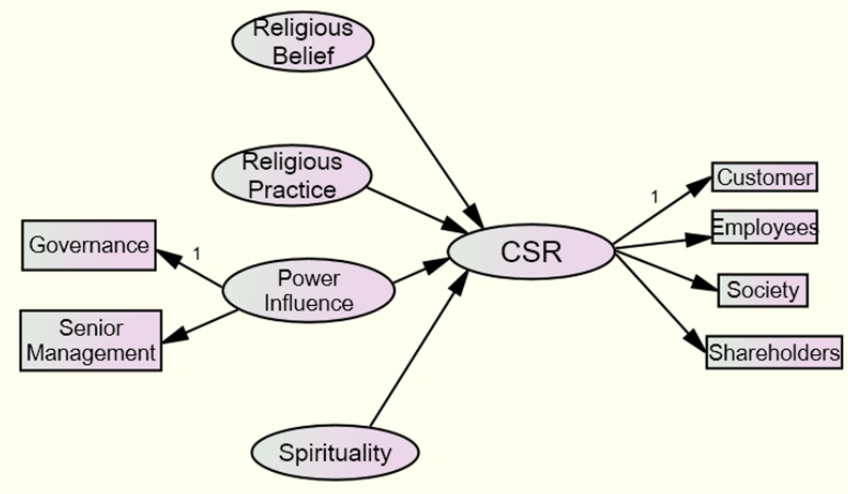

\section{Methodology}

\section{Research Setting}

We recognise New Zealand as the perfect research setting for our data collection, as family businesses in New Zealand are growing faster than their counterparts in Australia, with $42 \%$ growth in 2016 compared to $26 \%$ in 2014 (PWC Family Business Survey, 2017). Data was collected from the major regions in North and South Island, New Zealand. The study was was approved by the Ethics Committee of Pacific International Hotel Management School, New Plymouth, New Zealand (PIHMS 18/04). Due to the dispersion of the family businesses in New Zealand, we have used a combination of cold call and online survey. We set up two

\section{Page 188}

(c) 2019 Journal of Asia Entrepreneurship and Sustainability Vol XV, Iss 1, June 2019 RossiSmith Academic Publications, Oxford/London UK, www.publicationsales.com 


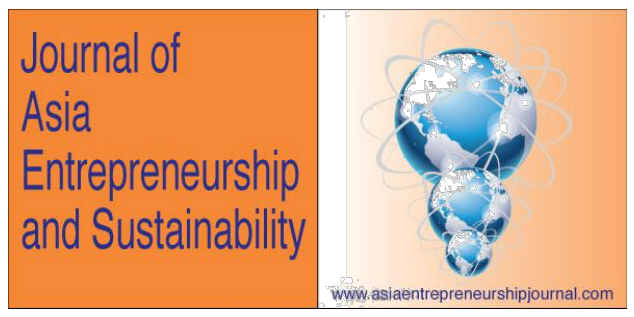

predetermined requirements for the sampling frame; that the business has to be a family business, but need not be run only by a husband or wife, and the respondents can be the founder, owner, member of the board of directors, a business partner, or other family members who work in the business. We believe these respondents are appropriate because they are the most important decisionmakers in family businesses (Sharma and Sharma, 2011). We have used several means to secure the list for family businesses; (1) New Zealand Registered Company, (2) cold calls in three major cities in North Island through our three research assistants, and (3) attending trade events. Prior to distributing the online link, we called the potential family businesses that were registered with New Zealand Company Registrar for permission to access the family members who work in the business and serve on the board. The cold calls were conducted in three major cities in North Island: Auckland, Wellington and Palmerston North. With three research assistants, we approached retailers and distributed the survey questionnaires or links to the online survey, whichever was preferred by the respondents. This is because we have strict requirements for the respondents. Participants were asked to complete the consent form and the survey within a week, and a thank-you card was also attached to the questionnaire. The completed questionnaires were collected in person. Additionally, we attended agricultural 


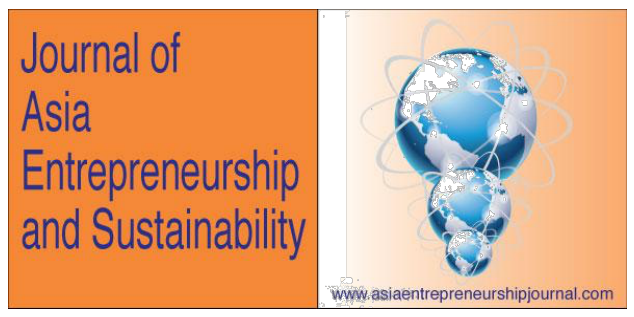

trade events in North Island because many farming, agricultural, and winery businesses in New Zealand belong to family businesses.

Subsequently, we received 272 responses from the 693 distributed questionnaire/links, yielding a 39.2 percent response rate. Of 272 responses, 21 were ineligible because the business did not fall under the definition of family businesses, or respondents were not affiliated with any religion. Following the suggestion of Cohen (1992) in calculating the sample size, we have selected an alpha $(\alpha)$ of .05 to minimise the possibility of Type 1 errors. Cohen (1992) also recommended aiming for a power $(1-\beta)$ of .8 or more to get an 80 percent or more chance of success. With regard to effect size (r), Cohen (1992) specified that large effects correspond to effect sizes of .5, medium effects correspond to effect sizes of .3 , and small effects correspond to effect sizes of .1 (Cohen, 1992). We have chosen small-to-medium effect size, i.e., .2 for this study. To sum up, the sample size of 251 respondents is able to detect almost $95 \%$ probability respectively at the effect size (r) of .2 and an alpha ( $\alpha$ ) of .05. Fifteen non-responding respondents were contacted by telephone and email to ascertain reasons for non-response. This revealed that the main reasons were (1) ineligibility, such as not being a family member, or (2) time constraints that prevented participation in the survey. 


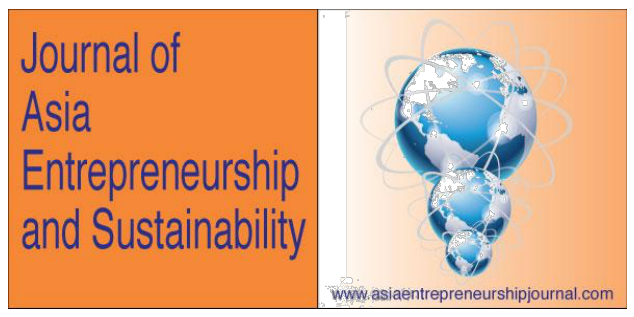

\section{Measures}

We measure spirituality using Delaney's (2005) Spirituality scale. The scale has 22 items in total and comprises three domains: Self-discovery (4 items), Relationships (6 items) and Eco-Awareness (12 items). Items include "I am happy about the person I have become" (Self-Discovery), "I value maintaining and nurturing my relationships with others" (Relationships) and "I believe there is a connection between all things that I cannot see but sense" (Eco-Awareness). The responses were measured on a 5 -point Likert scale $(1=$ strongly disagree, $5=$ strongly agree $)$. Religious practice and religious belief were measured using Lewis and Kashyap's (2013) scale. We used this scale because it is applicable to many religious beliefs. These scholars have used and validated this measure in Britain through various religious beliefs, namely Muslims, Christian, Jewish, Hindu, Sikh, and Buddhist. Religious practice comprises three items and was measured in terms of attending weekly services, daily prayers, and reading scripture daily. Religious belief also comprises three items, including "I am absolutely sure I believe in God". Similar to the spirituality scale, these were measured on a 5-point Likert scale. Family power influence was measured using F-PEC (Astrachan, Klein and Smyrnios, 2002). There are three items in total, including percentage of family members in managing positions in the firm, percentage of family members on the board, and percentage of family-owned stocks. We have dropped the percentage of 


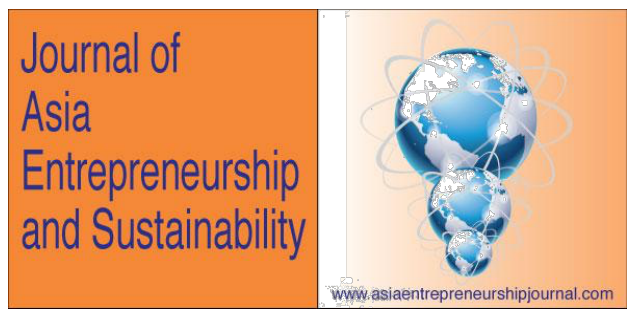

stocks item because family ownership in the study accounted for $100 \%$ (e.g., none is listed as a public company), so this item is constant in the sample.

The ethical values towards corporate social responsibility were measured using Perez and del Bosque's (2013) scale. The scale has 20 items in total and comprises four domains: ethical values toward customers ( 5 items), ethical values toward employees (5 items), ethical values toward stakeholders (4 items) and ethical values toward society (6 items). Items include "establishes procedures to comply with customers' complaints" (customers), "treats employees fairly without discrimination or abuse" (employees), "tries to ensure its survival and long-term success" (stakeholders) and "concerns with respecting and protecting the natural environment" (society). These were also measured with a 5-point Likert scale. We have dropped three items from the spirituality scale and one item from ethical values toward society due to low factor loadings $<.4$ (Hair et al., 2006). We also added a few demographic questions for the participants and also the company pertaining to size, age, type of industry, and religious affiliation. All religious affiliation except "no particular religion" and "other" were kept in our estimation model. 


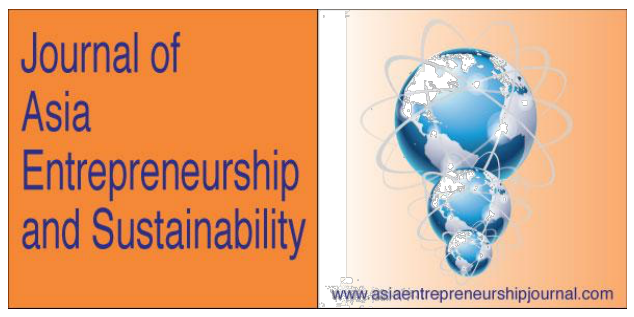

\section{Results}

We have used structural equation modelling (SEM) based on AMOS to test our posited hypotheses. We performed three major types of analyses: (1) correlation, (2) building baseline model and measurement model validation, and (3) testing posited hypotheses including mediation evaluations. Following Little et al.'s (2002) suggestion, since we are not interested in examining the effects of independent variables on each dependent variable separately, we have parcelled 20 items of customers, employees, stakeholders, and society into fours and called the latent Corporate Social Responsibility and the indicators as CUS, EMP, SOC, and SH. A similar process was conducted for spirituality indicators, as we are not interested in examining each domain of spirituality, we have parcelled the indicators into 7 items based on the factor loadings. The measure of Maximum Likelihood was chosen, and the parameters were freely estimated. Ultimately, the measurement model is built to assess the confirmatory factor analysis (CFA) on five latent variables and 19 indicators ( 3 indicators for religious practice, 3 indicators for religious beliefs, spirituality 7 , family influence power 2 , and corporate social responsibility 4 . The initial model (Model 1) was found to be slightly insignificant $(\mathrm{CFI}=.824, \mathrm{NFI}=.803, \mathrm{CMIN}=785.78, \mathrm{DF}=281$, $\mathrm{CMIN} / \mathrm{DF}=2.689, \mathrm{RMSEA}=0.085)$. Then we assessed the modification indices for covariance between estimated errors. We found item 2 and item 3 of religious 


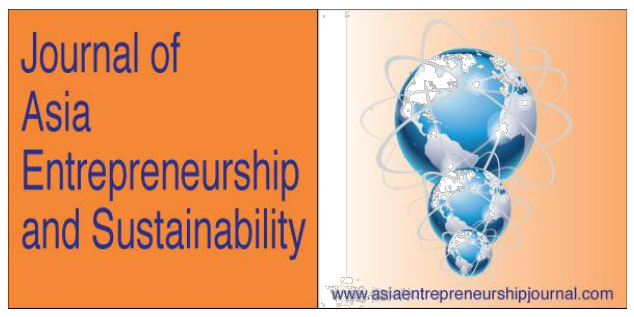

practice had extremely high modification index (71.24) indicating that the two items measured the same thing, resulting in dropping item 2. After that, we re-ran the model. The final model shows model fit. d.f. $\chi^{2}=758.80 ; \mathrm{df}=540 ;(\chi 2 /$ d.f $)=$ 1.405; Normed Fit Index $(N F 1)=.901$; Non-normed Fit Index $(N N F 1)=.917$; Comparative Fit Index $(\mathrm{CFI})=.911$; Root Mean Squared Error of Approximation $($ RMSEA $)=055 ; \mathrm{p}-$ Value $\leq .01$. We also estimated construct reliability and Cronbach alphas and found all to be above the construct threshold $(\geq .7)$ as recommended by Nunnally $(1978 ; 1988)$. A summary of the measurement model is depicted in Table 1. Table 2 shows the demographic results, and Table 3 shows the correlation results. Then we tested the posited hypotheses, concurrently including the effects of indirect variables. We adopted Byrne's (2001) procedure for testing mediation/indirect variables using SEM in AMOS. To sum up, we found positive effect of spirituality on corporate social responsibility. Surprisingly, the effect of religious practice was negative whilst the effect of family power domain and religious beliefs on sustainability were insignificant. The results are shown in Figure 2 and Table 3. 


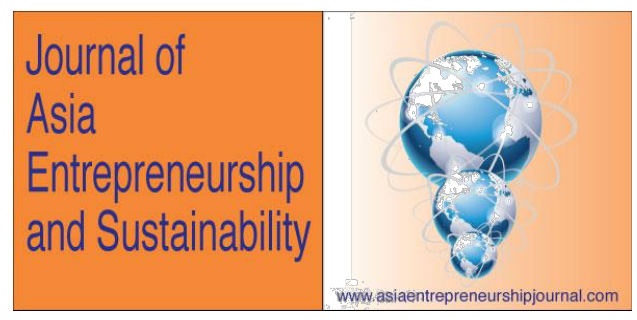

Fig 2: Regression Results

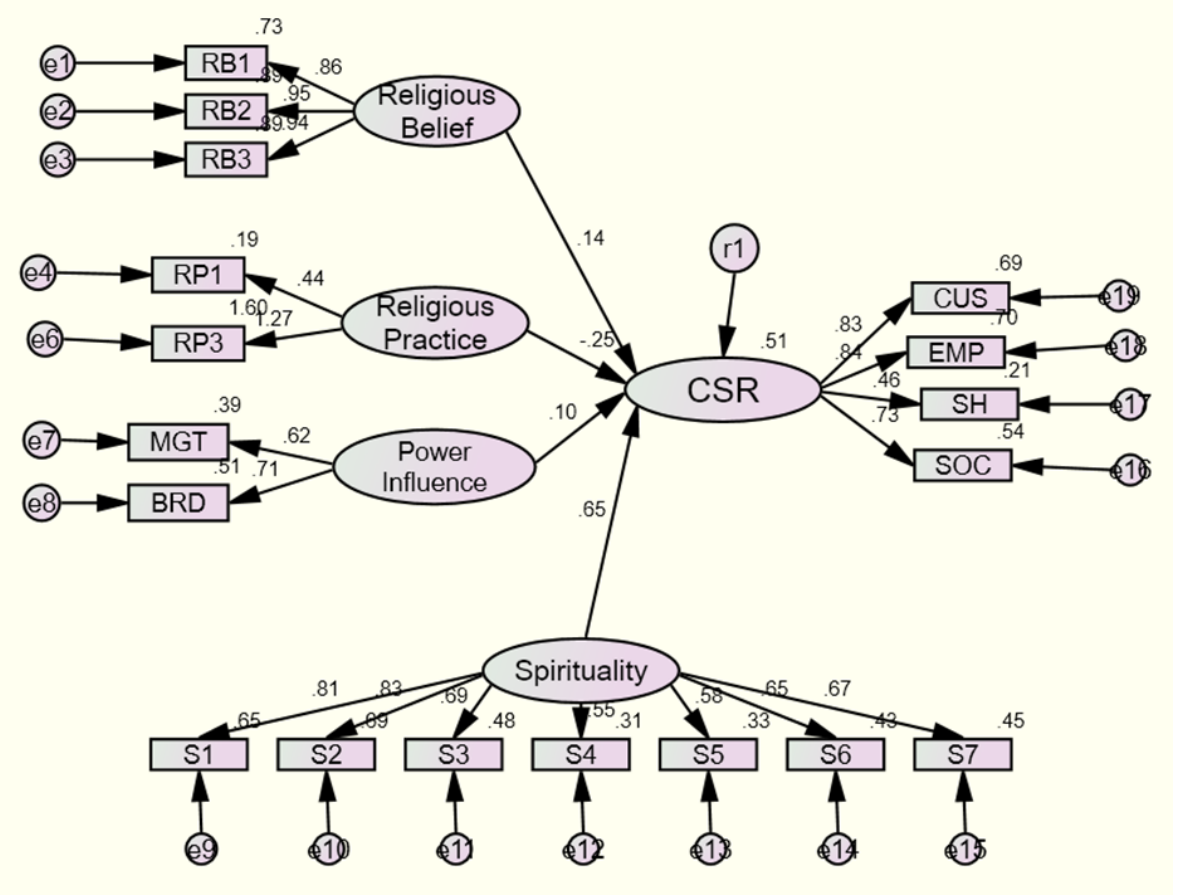

Page 195

(C) 2019 Journal of Asia Entrepreneurship and Sustainability Vol XV, Iss 1, June 2019

RossiSmith Academic Publications, Oxford/London UK, www.publicationsales.com 


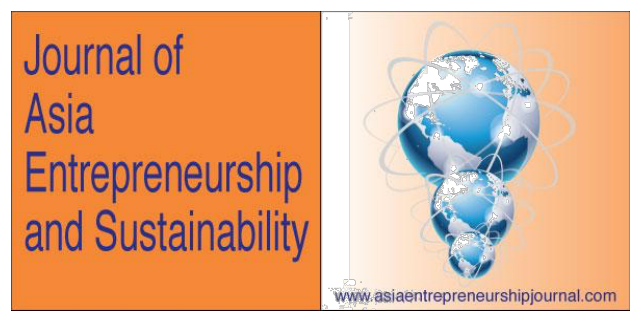

Table 1: Measurement Model

\begin{tabular}{|c|c|c|c|c|c|}
\hline Censtruets/Trems & Losding: & (e) & AVE & Mesn & SD \\
\hline Spirituality (S) & & 84 & 39 & 3.948 & 301 \\
\hline Find mesuning in Ifo experiance S01 & .68 & & & & \\
\hline Hanv a sana of parpoia $\$ 02$ & .79 & & & & \\
\hline Haggy abour the pervon I bave become $\$ 03$ & .76 & & & & \\
\hline Ses sacretuen of everyday lifo $\mathrm{SO} 4$ & .60 & & & & \\
\hline Bebeve all living cresture dererve respect SOS & .69 & & & & \\
\hline Valus mointaining and mutring with others S05 & .65 & & & & \\
\hline Belierve nanre abould be respectad 507 & .65 & & & & \\
\hline Am able to recaivo lowe from other $\$ 08$ & .76 & & & & \\
\hline Stive to contect avcenes in mp lifentyle $\$ 09$ & $\$ 1$ & & & & \\
\hline Rerpect dinerivity of people $\$ 010$ & .67 & & & & \\
\hline Maditato to min imer mecess SOII & .78 & & & & \\
\hline Livo in harroum with nahue SO12 & .73 & & & & \\
\hline Beberv thare is counaction botuean all things 5013 & SS & & & & \\
\hline Lifo is a procen of becouning 5014 & 78 & & & & \\
\hline Earth is sacted $\$ 016$ & 77 & & & & \\
\hline Use vilant to ast in tonch with novelf $\$ 017$ & .75 & & & & \\
\hline Spuinality wivo mo imper strencth $\$ 019$ & .68 & & & & \\
\hline Prayer is integnl purt of pintinality nature S021 & .65 & & & & \\
\hline 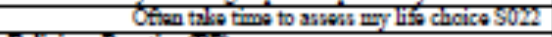 & .65 & & & & \\
\hline Retipious Practice (RP) & & .736 & .78 & 3.004 & 909 \\
\hline Artad services weolky RPI & 71 & & & & \\
\hline Pray doily $R P 2$ & .53 & & & & \\
\hline Bead vcripture dvily RP3 & 61 & & & & \\
\hline Relipious Belief (RB) & & 949 & .66 & 3.685 & 1.033 \\
\hline Balierv in God RIBI & 91 & & & & \\
\hline Raligicn important in donylifo RE2 & 90 & & & & \\
\hline Religico important to sease of valf RB3 & 79 & & & & \\
\hline Customers (CUS) & & 904 & .65 & 4.011 & .803 \\
\hline $\begin{array}{r}\text { Eatsblishas procedure to comply with customer } \\
\text { complaims } \mathrm{Cl}\end{array}$ & .66 & & & & \\
\hline Trests customers bosontly $\mathrm{C}_{2}$ & .68 & & & & \\
\hline Offen conplete infermaticn about comperste products C3 & .77 & & & & \\
\hline Une customer satisfacticu as indicater to imrorono CA & 72 & & & & \\
\hline MShe an effort to luow cubtomer need CS & $\overline{82}$ & & & & \\
\hline Sharebolders (SH) & & .740 & .46 & 3.973 & 390 \\
\hline Tries to movimise profits SHI & 71 & & & & \\
\hline Feep a striet control avar its cont SH2 & .75 & & & & \\
\hline Fnares its rarvival and long-torm success SA33 & .66 & & & & \\
\hline Thforme economic whution to stakebolders SH4 & 95 & & & & \\
\hline Employes (2MI) & & 909 & .64 & 4.054 & .837 \\
\hline Pay bir salsnas EPI & .75 & & & & \\
\hline Ofex wafety at wodk EP2 & .67 & & & & \\
\hline Treats enployw firly EP3 & $\$ 2$ & & & & \\
\hline Offer trining and carosr ogpontanitios EP4 & .66 & & & & \\
\hline Offer plassant work emiromment EPS & & & & & \\
\hline Society $(\$ O C)$ & & SSI & 38 & 3.529 & .724 \\
\hline Help soks social problem SCI & .63 & & & & \\
\hline 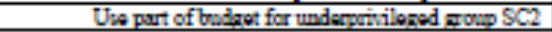 & .90 & & & & \\
\hline Conpribute to cuinnal and rocial erent: SC3 & .69 & & & & \\
\hline Pler rolo in the wociery borend eccoomic benefit SC4 & .52 & & & & \\
\hline Concerned improting meneral woll-baing of society SCS & .78 & & & & \\
\hline
\end{tabular}

Page 196

(C) 2019 Journal of Asia Entrepreneurship and Sustainability Vol XV, Iss 1, June 2019

RossiSmith Academic Publications, Oxford/London UK, www.publicationsales.com 


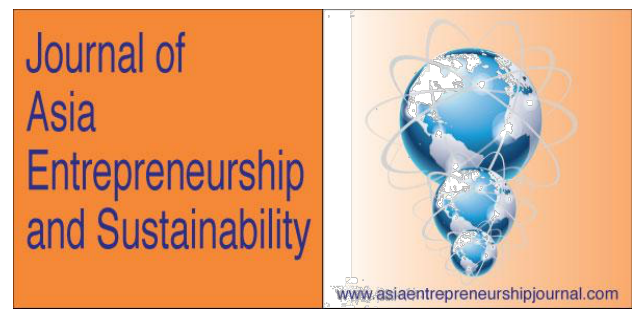

Table 2: Demographic Statistics

\begin{tabular}{|c|c|c|c|}
\hline Variable & & Frequency & (\%) \\
\hline \multicolumn{4}{|c|}{ Relationship to Family } \\
\hline \multicolumn{4}{|l|}{ Business } \\
\hline & $\begin{array}{l}\text { Family Member (By } \\
\text { blood) }\end{array}$ & 200 & 79.7 \\
\hline & By Marriage/De facto & 48 & 19.1 \\
\hline & Others & 3 & 1.2 \\
\hline \multicolumn{4}{|l|}{ Position $(\mathrm{N}=251)$} \\
\hline & Owner/Partner & 100 & 39.8 \\
\hline & CEO & 16 & 6.4 \\
\hline & Senior Manager & 55 & 21.9 \\
\hline & Middle Manager & 30 & 12.0 \\
\hline & Others & 50 & 19.9 \\
\hline \multicolumn{4}{|l|}{ Gender $(N=251)$} \\
\hline & Male & 158 & 62.9 \\
\hline & Female & 93 & 37.1 \\
\hline \multicolumn{4}{|l|}{ Religion $(\mathrm{N}=251)$} \\
\hline & $\begin{array}{l}\text { Christian (all } \\
\text { denominations) }\end{array}$ & 144 & 57.4 \\
\hline & Islam & 46 & 18.3 \\
\hline & Hindu & 36 & 14.3 \\
\hline & Buddhism & 20 & 8.0 \\
\hline & Judaism & 5 & 2.0 \\
\hline \multicolumn{4}{|c|}{ Age Group $(\mathrm{N}=251)$} \\
\hline & $18-24$ years old & 24 & 9.6 \\
\hline & $25-34$ years old & 42 & 16.7 \\
\hline & $35-44$ years old & 66 & 26.3 \\
\hline & $45-54$ years old & 83 & 33.1 \\
\hline & $55-64$ years old & 30 & 11.9 \\
\hline & $65+$ years old & 6 & 2.4 \\
\hline
\end{tabular}

\begin{tabular}{|c|c|c|c|c|c|c|c|c|c|c|}
\hline Variable & Mean & SD & $\mathrm{RP}$ & & & & & CSR3 & CSR4 & POUFP \\
\hline Religious & 3.004 & .909 & 1 & & & & & & & \\
\hline $\begin{array}{l}\text { Practice RP) } \\
\text { Religious }\end{array}$ & 3.685 & 1.033 & $.643^{* *}$ & 1 & & & & & & \\
\hline $\begin{array}{l}\text { Belief (RB) } \\
\text { Spirituality }\end{array}$ & 3.948 & .501 & $.583^{* *}$ & & 1 & & & & & \\
\hline & & & & & & & & & & \\
\hline $\begin{array}{l}\text { Customer } \\
\text { (CUS) }\end{array}$ & 4.011 & .803 & .071 & $.275^{* * *}$ & $.437^{* *}$ & 1 & & & & \\
\hline $\begin{array}{l}\text { Shareholder } \\
\text { (SH) }\end{array}$ & 3.973 & .590 & -.066 & .093 & $.206^{* *}$ & $.473^{* *}$ & 1 & & & \\
\hline $\begin{array}{l}\text { Employees } \\
\text { (EMP) }\end{array}$ & 4.054 & .837 & .090 & $.283^{* *}$ & $.463^{* *}$ & $.693^{* *}$ & $.275^{* *}$ & 1 & & \\
\hline Society (SOC) & 3.529 & .724 & $.298^{* *}$ & $.278^{* *}$ & $.556^{* *}$ & $.531^{* *}$ & $.270^{* *}$ & $.275^{* *}$ & 1 & \\
\hline Power & .46 & .995 & $.165^{*}$ & .095 & $.270^{* *}$ & .122 & $.225^{* *}$ & $.144^{*}$ & .087 & 1 \\
\hline
\end{tabular}

Page 197

(C) 2019 Journal of Asia Entrepreneurship and Sustainability Vol XV, Iss 1, June 2019

RossiSmith Academic Publications, Oxford/London UK, www.publicationsales.com 


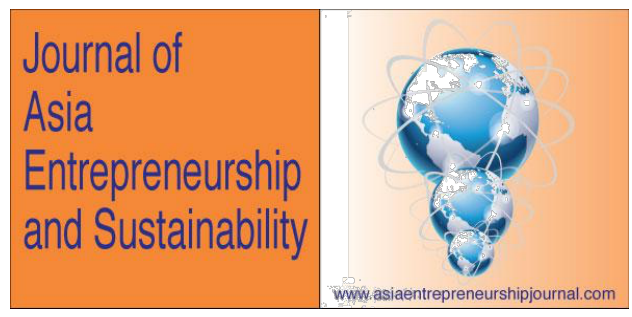

\section{Discussion}

\section{Contribution to Theory}

The primary finding of the study is humbling. We found the level of spirituality of the owning family and partners positively affects the business corporate social responsibility as measured by attitudes toward employees, customers, society, and stakeholders. There is a straightforward explanation; although some would argue that spirituality is a complex phenomenon (Delaney, 2005), others agree that spirituality is about relationships - human to human, human to nature, and human to cosmic reality (Caleb, 2003). Therefore, it is not unexpected to see the positive effect of spirituality on corporate social responsibility among family businesses. The finding of this study also advances the literature on spirituality and corporate social responsibility in family businesses by signifying that the concept of spirituality is indeed different from religiosity.

Perhaps one of the most surprising findings of our research is that we found no significant effect of the level of family influence on the family business's towards corporate social responsibility. Our finding contradicts Klein et al. (2005) and Sharma and Sharma (2011) studies that found positive relationship between these two variables. We can offer two possible explanations for the phenomenon. First, our study is conducted in New Zealand, a developed country that has strict 


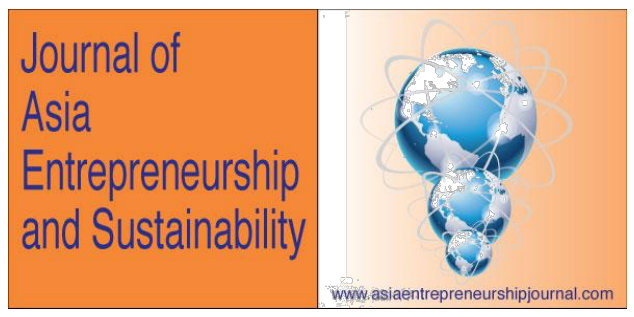

regulations towards its environment, employees and customers' rights. The majority of family businesses in this study have committed to corporate social responsibility regardless whether the family power influence is low or high. Indeed, the average mean of the corporate social responsibility practice towards employees and societies were significantly high at 4.011 an 4.054 respectively. Second, the average of the family power domain that was measured by the percentage of family members on the board and senior management position in this study was relatively low at 46 percent. Therefore, they might not be strong enough to influence the businesses' systems and policies towards the practice of corporate social responsibility. It is worth noting that studies have found the success of family businesses in New Zealand to be determined mainly by the balance of specialist management teams and family members working in the positions for which they are most qualified (Shanahan, Robb and Lord, 1999).

The study also observed the impact of religious practice on family business corporate social responsibility was in negative relationship. Our study contradicts qualitative study by Paterson et al. (2013) that have observed family business is all about God and how religion influences and shapes their business. It is worth noting that the means for religious practice in our study are somewhat low (3.004 on the scale 1 to 5), indicating that respondents are not really religious (practicing 


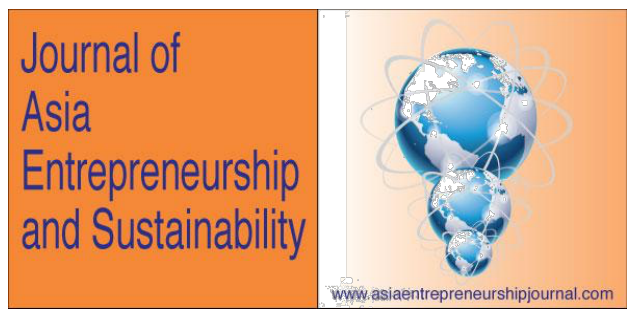

religion) as defined by Lewis and Kasyap's (2013) scale. We have also found that the regression effect between religious practice and family power influence is small. There are several potential explanations for this phenomenon. Firstly, the overt practice and emphasis on religion can lead to conservatism (Stankov, 2016). When a person is too focused on a particular stream, they tend to be stubborn in their views, resulting in neglecting others. Strong religious practice has also been linked to strongly manipulative, nasty, or otherwise negative behaviour (Stankov and Lee, 2016). The work of Vitell et al. (2007) also observed that religious practice (or, as they term it, extrinsic religiosity) had a negative correlation with consumer ethics and activities. Translating this to a family business management, if the organisation were overly controlled by a certain religious practice, it could lead to conservatism and conflict, which resulted in corporate governance problems. Additionally, if these beliefs are not shared equally by other family members or senior partners, it may cause conflict in the longer run. As observed by Morck and Yeung (2003), corporate blindness due to seeing and hearing the same ideas could lead to cynical management and low firm performance. Indeed, studies have also found negative correlations between religious behaviour like attendance at religious services and economic growth (McCleary and Barro, 2006). 


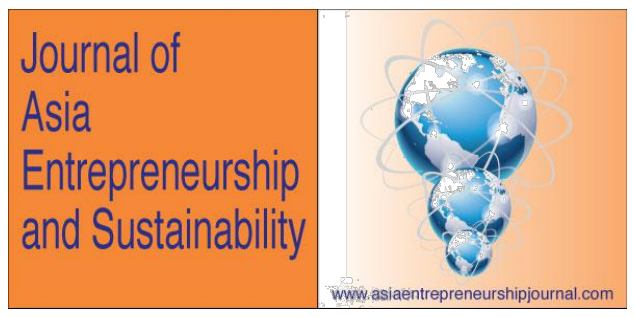

Secondly, the literature has recognised that family businesses always strive for stability and long-term survival. Due to the desire to sustain the business for generations, they are likely to act rationally in a particularistic manner beyond the religious practice of the founder. Indeed, as questioned by Rau, Astrachan and Smyrnios (2018), "when a company is growing, highly profitable, has low debt, happy customers and suppliers, paying good dividends, and living the values desired by the family, for what reasons would family exert high levels of influence?" (p. 202). We believe this could be the case with our findings. Thirdly, the explanation could lie in the high percentage of participating family members across multiple generations and employees with diverse religious backgrounds and values, which could lead to conflict at work if only one set of religious values is imposed. A participating family with multiple generations might have different levels of education and exposure than the founder. When a person acquires higher education, they tend to be associated with fewer religious beliefs, resulting in becoming less religious (Sherkat and Ellison, 1999). Though it is not the main objective of our study, we have also discovered that the effect of globalisation and diverse customer needs have led family businesses to adjust their business systems for long-term survival. 


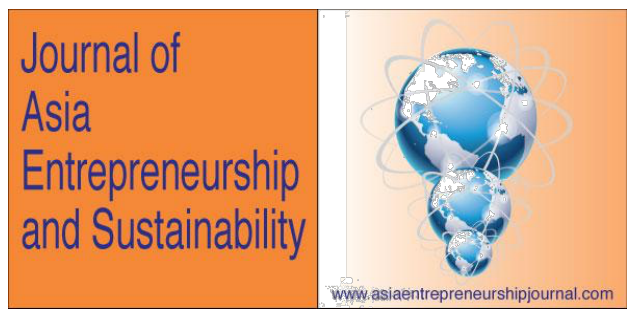

\section{Practical Implication}

The findings of this study provide several implications for managers who work in family business and other external stakeholders dealing with family businesses. There is a relationship between spirituality values of family members in family businesses and their attitude towards corporate social responsibility. Managers and employees working for family businesses need to understand the extent to which family businesses' spirituality may affect their own as well as others ethical conducts. Nonetheless managers are spiritual and has spiritual needs (Ayoun et al., 2014) and spirituality should be valued as a source of ethical directions in work places. Workplaces could provide avenues for their employees to express spirituality in the workplace. Other external stakeholders dealing with family businesses could also understand the attitude of family businesses towards corporate social responsibility by examining the level of spirituality values. A better understanding of the level of spirituality values and family power influences in family businesses helps external stakeholders to make accurate trading and investment decisions.

\section{Limitations and Future Study}

This study has several limitations that provide avenues for future research. First, the study does not differentiate among denominations within each single religion. 


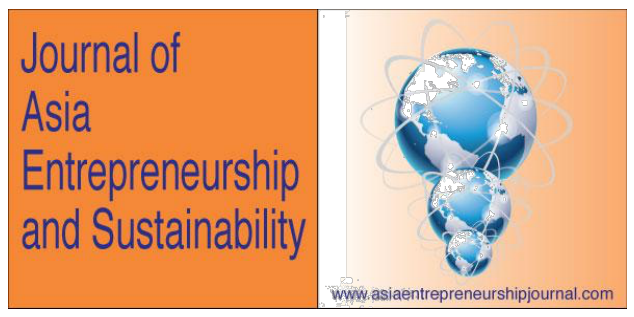

For example, we did not differentiate between the Sunni and Shiah Muslims, or among Catholics, Protestants, and Orthodox Christians. One could argue that the values, lifestyles and social attitudes among these believers differ. Nevertheless, it was not the aim of the study to compare and contrast the details of each religion. Second, our study measures religiosity and spirituality through self-reported. Selfreported measures can be subject to various distortions, including faking of answers and elements of bias. However, this measure seemed particularly appropriate as indicators of religiosity, spirituality, and their effect of family business values in this context is from the family business owners' perception. In addition, past studies have reported that self-reported measures do not demonstrate any particular upward bias (Strauss et al., 2001). Hence, the use of self-reported measures in this study may constitute only a minor limitation. Third, in analysing the data using SEM, we have parcelled our items (Little et al., 2002) have not therefore discovered different strengths for each item in each domain. It was not the intention of the study to examine the strengths of each item, and extra care has been taken when parcelling. Finally, religious belief and practice are not the only domains for religiosity. For example, Chowdhury (2018) measures religiosity through intrinsic and extrinsic religiosity, while Batson and Gary (1981) have added another domain of quest religiosity, and other scholars like Ali (2005) have measured Muslim religiosity of using different domains. Future research could 


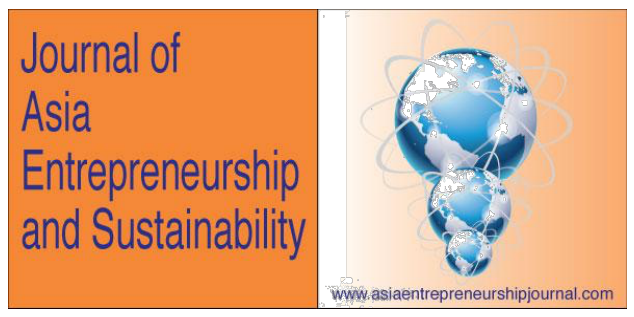

examine these domains and measure religiosity differently to ascertain if they support or contradict our results. Finally, our study was conducted in New Zealand, a Western country that embraces diversity and is arguably a less religious country. Perhaps the effect of religious practice was not significant due to this fact. Future studies could test the effect of religiosity on family business systems and policies in different settings. The family businesses under study were mainly small to medium-sized enterprises of less than 250 employees. Future studies could illuminate the effects of religiosity on larger family businesses.

\section{Conclusion}

In conclusion, this empirical study provides evidence that although the level of spirituality does influence the family business corporate social responsibility towards its employees, customers, stakeholders and society at large, the level of religious beliefs and religious practice of the owning family members do not. However, the effect of the religious belief and practice on the company's social responsibility was an indirect, through family power influence variable. 


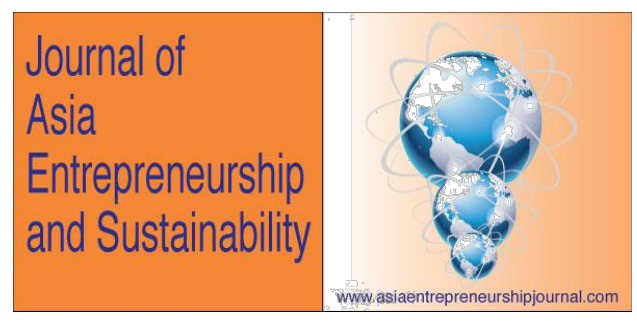

\section{References}

Aguinis, H. (2011). Organizational responsibility: Doing good and doing well. In S. Zedeck (Ed.), APA Handbook of Industrial and Organizational Psychology (Vol. 3): 855-879. Washington, DC: American Psychological Association. Ajzen, I. (1991). The theory of planned behaviour. Organizational Behavior and Human Decision Processes, 50(2), 179-221.

Ajzen, I. \& Fishbein, M. (1980). Understanding attitude predicting behaviour. Englewood Cliffs, NJ: Prentice Hall.

Ali, A. J. (2005). Islamic perspectives on management and organization. Northamton, Massachusetts, Edward Elgar Publishing Inc.

Annalakshmi, N. \& Abeer, M. (2011). Islamic worldview, religious personality and resilience among Muslim adolescent students in India, Europe's Journal of Psychology, 7(4), $716-738$.

Astrachan, J.H., Klein, S.B. \& Smyrnios, K. (2002). The F-PEC scale of family influence: A proposal for solving the family business definition problem. Family Business Review, 15(1), 45-58.

Audretch, D.B. Bonte, W. \& Tamvada, J.P. (2007). Religion and entrepreneurship, CEOR Discussion Paper No. DP6378.

Ayoun, B., Rowe, L. \& Yassine, F. (2015). Is workplace spirituality associated with business ethics? International Journal of Contemporary Hospitality Management, 27(5), 938-957.

Barnett, T. Bass, K. \& Brown, G. (1996). Religiosity, ethical ideology, and intentions to report peer's wrong doing. Journal of Business Ethics, 15, 1161-1174. Bhasi, M. Renuka, V.V. \& Rajkumar, S. (2017). A study on influence of religion and inheritance in family business. Journal of Management, 14(1), 31-50.

Batson. C.D. \& Gray, R.A. ((1981). Religious orientation and helping behavior: Responding to one's own or the victims' needs? Journal of Personality and Social Psychology, 40(3), 511-520. 


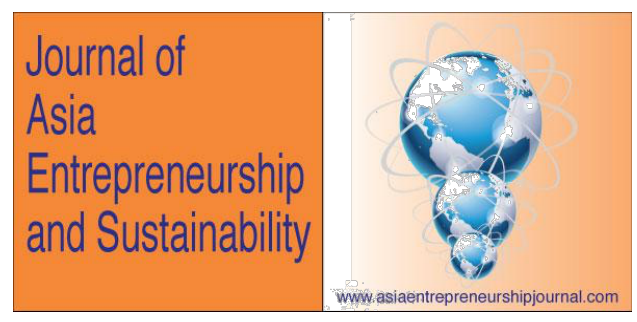

Bozeman, B. \& Murdock, A. (2007). Public managers' religiosity: Impact on work attitudes and perceptions of co-workers. International Public Management Journal, 10(3), 287-306.

Brammer, S, Williams, G \& Zinkin, J. (2007) Religion and attitudes to corporate social responsibility in a large cross-country sample. Journal of Business Ethics, 71(3), 229-243.

Burkhardt, M.A. \& Nagai-Jacobson, M.G. (2002). Spirituality: Living our connectedness. Albany, NY: Delmar.

Byrne, B. (2013) Structural equation modeling with AMOS: Basic concepts, applications and programming, $2^{\text {nd }}$ edition, Mahwah, New Jersey, Lawrence Erlbaum.

Campante, F. and Yanagizawa-Drott, D. (2015). Does religion affect economic growth and happiness? Evidence from Ramadan. The Quarterly Journal of Economics, 615-658.

Charisman, J.J., Chua, J.H. \& Sharma, P. (2005). Trends and directions in the development of a strategic management theory of the family firm.

Entrepreneurship: Theory and Practice, 29(5), 555-579.

Chowdhury, R.M.M.I. (2018). Religiosity and voluntary simplicity: The mediating role of spiritual well-being. Journal of Business Ethics, 152, 149-171.

Chua, J.H. Chrisman, J.J. \& Sharma, P. (1999). Defining the family business by behavior. Entrepreneurship: Theory and Practice, 23(4), 19-39.

Cornwall, M. Albrecht, S.L. Cunningham, P.H. \& Pitcher, B.L. (1986). The dimension of religiosity: A conceptual model with empirical test. Review of Religious Research 27(3), 226-243.

Cruz, A. D., Hamilton, E. and Jack, S.L. (2012). Understanding entrepreneurial cultures in family businesses: A Study of family entrepreneurial tems in honduras. Journal of Family Business Strategy, 3, 147-161.

Dahlsrud, A. (2008). How corporate social responsibility is defined: An analysis of 37 definitions. Corporate Social Responsibility and Environment Management, 15(1), 1-13. 


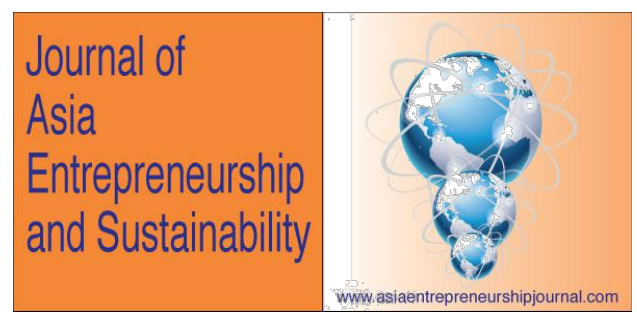

Delaney, C. (2005). The spirituality scale: Development and psychometric testing of a holistic instrument to assess the human spiritual dimension. Journal of Holistic Nursing, 23(2), 145-167.

Discua Cruz, A. (2013). Christian family businesses: Opportunities for future research. Journal of Biblical Integration in Business, 16(2), Durendez, A. \& Madrid-Guijarro, A. (2018). The impact of family influence on financial reporting quality in small medium family firms. Journal of Family Business Strategy, 9, 205-218.

Dyer, W.G. \& Whetten, D.A. (2006). Family firms and social responsibility. Preliminary evidence from the S\&P 500. Entrepreneurship Theory and Practice, 30(6), 785-802.

Dyson, J., Cobb, M. \& Forman, D. (1997). The meaning of spirituality: A literature review. Journal of Advanced Nursing, 26, 1183-1188.

Ellingsen, I.T., Stephens, P. \& Storksen, I. (2012). Congruence and incongruence in the perception of family among foster parents, birth parents and their adolescent (foster) children. Child \& Family Social Work, 17(4), 427-437.

Elsi, M. (2007). Effect of manifest needs, religiosity and selected demographics on hard working: An empirical investigation in Turkey. Journal of International Business Research, 6(2), 97-121.

Ferm, V. (1963). An Encyclopedia of Religion. London. Peter Owens.

Ferra, A.A. (2009). Islam: Worldview and way of life. $2^{\text {nd }}$ ed. Kuala Lumpur: ABIM

Fox, C., Webster, B. D. \& Casper, W.C. (2018). Spirituality, psychological capital and employee performance: An empirical examination. Journal of Managerial Issues, 30(2), 194- 213.

Frankl, V.E. (2000). Man's search for meaning. Boston: Beacon. (Original work published 1959).

Garcia-Zamor, J. (2003). Workplace spirituality and organizational performance. Public Administration Review, 63(3), 355-363. 


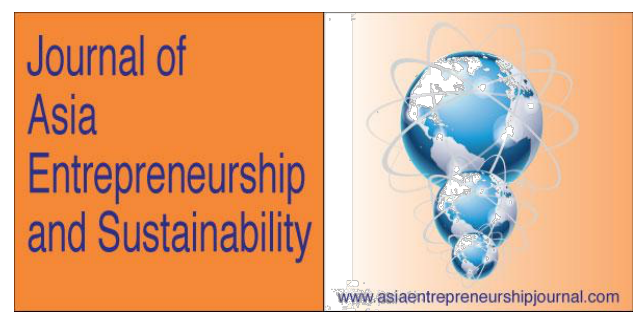

Ghosh, A.A. \& Tang, C. Y. (2015). Assesing financial reporting quality of family firms: The auditors perspective. Journal of Accounting and Economics, 60(1), 95116.

Giacolone, R. \& Jurkiewicz, C. (2003). Towards a science of workplace spirituality, Chapter in Handbook of Workplace Spirituality and Organizational performance. Eds.R. Giacalone \& C. Jurkiewicz. New York, NY: M.E Sharpe. 328.

Godfrey, P.C. (2005). The relationship between corporate philanthropy and shareholder wealth: A risk management perspective. Academy of Management Review, 30(4), 777-798.

Heaven, P., C.L., \& Ciarrochi, J. (2007). Personality and religious values among adolescents: A three-wave longitudinal analysis. British Journal of Psychology, 98, 681- 694

Issa, T., \& Pick, D. (2010). Ethical mindsets: An Australian study. Journal of Business Ethics, 96 (4), 613-629.

Issa, T., \& Pick, D. (2011). An interpretive mixed-methods analysis of ethics, spirituality, and aesthetics in the Australian services sector. Business Ethics: A European Review, 20(1), 45-58.

Jara Bertin, M., \& Iturriaga Lopez, F.J. (2014). Earnings management and the contest to the control: An international analysis of family-owned firms. Spanish Journal of Finance and Accounting, 43(4), 355-379.

Johnson, B. R., Jang, S. J., Larson, D. B., \& Li, S. D. (2001). Does adolescent religious commitment matter? A re-examination of the effects of religiosity on delinquency. Journal of Research in Crime and Delinquency, 38(1), 22-43 Karakas, F. (2010). Spirituality and performance in organization: A literature review. Journal of Business Ethics, 94, 89-106.

Kellermans, F.W. (2013). Spirituality and religions in family firms. Journal of Management, Spirituality \& Religion, 10(2), 112-115.

King, S. M. (2007). Religion, spirituality and the workplace: Challenges for public administration. Public Administration Review, 67(1), 103. 


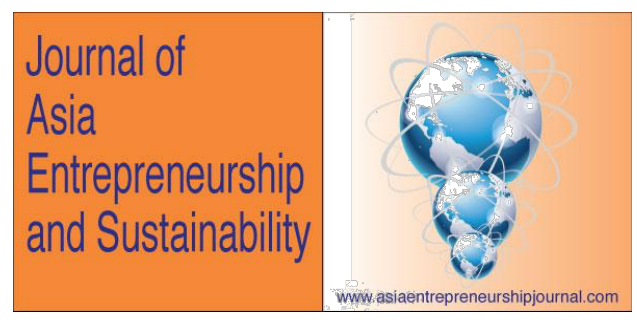

Klein, S.B. Astrachan, J.H. \& Smyrnios, K.X. (2005). The F-PEC scale of family influence: Construction, validation and further implication for theory.

Entrepreneurship Theory and Practice, 37, 1268-1339.

Korac-Kakabadse, N., Kouzmin, A \& Kakabadse, A. (2002). Spirituality and leadership praxis. Journal of Managerial Psychology, 17(3). 165-182.

Lewis, VA \& Kashyap, R. (2013). Are Muslims a distinctive minority? An empirical analysis of religiosity, social attitude and Islam, Journal for the Scientific Study of Religion, 52(3), 617-626

Little, T. D., Cunningham, W. A., Shahar, G., \& Widaman, K. F. (2002). To parcel or not to parcel: Exploring the question, weighing the merits. Structural Equation Modeling, 9(2), 15-73

Martin, J.E \& Carlson, C.R. (1998). Spiritual dimensions of health psychology, in Miller, W.R \& Martin, J.E. (Eds), Behaviour Therapy and Religion: Integrating Spiritual and Behavioral Approaches to Change. Newbury Park, CA: Sage. McCleary, R.M., \& Barro, R.J. (2006). Religion and political economy in an international panel. Journal of Science Study of Religion, 45(2), 149-175. Morck, R. \& Yeung, B. (2003). Agency problems in large family business groups. Entrepreneurship: Theory and Practice, 27(4), 367-388.

Pargament, K.I. (1992). Of means and ends: Religion and the search for significance. International Journal for the Psychology of Religion, 2, 201-29. Paterson, T.A., Specht, D., \& Duchon, D. (2013). Exploring costs and consequences of religious expression in family businesses. Journal of Management, Spirituality and Religion, 10(2), 138-158.

Perez, A. \& del Bosque, I.R. (2013). Measuring CSR image: Three studies to develop and to validate a reliable measurement tool. Journal of Business Ethics, 118, 265-286.

Rau, S. B., Astrachan, J.H. \& Smyrnios, K.X. (2018). The F_PEC revisited: From the family business definition dilemma to foundation of theory. Family Business Review, 31(2), 200-213. 


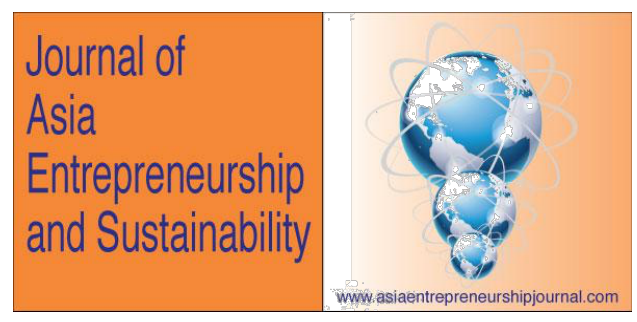

Ramadi, V. \& Hoy, F. (2015). Context and uniqueness of family business, in L. Dana and V. Ramani,, eds. Family Business in Transition Economies,. Switzerland: Springer, 9-37.

Roccas, S. (2005). Religion and value systems. Journal of Social Issues, 61, 747759.

Rozuel, C., \& Kakabadse, N. (2010). Ethics, spirituality and self: managerial perspective and leadership implications. Business Ethics: A European Review, 19(4), 423-436

Sengupta, S. S. (2010). Correlates of spiritual orientation \& managerial effectiveness. Indian Journal of Industrial Relations, 45-60.

Senegovic, I. Bublic, V. \& Coric, G. (2015). Family business succession risks: the Croatian context, in L. Dana and V. Ramani,, eds. Family Business in Transition Economies,. Switzerland: Springer, 175-197.

Sharma, P. \& Chua, J.H. (2013). Asian family enterprises and family business research. Asia Pacific Journal of Management, 30, 641-656.

Sharma, P. \& Sharma, S. (2011). Drivers of proactive environmental strategy in family firms. Business Ethics Quarterly, 21(2), 309-334.

Sorenson, R.L. (2013). How moral and social values become embedded in family firms. Journal of Management, Spirituality \& Religion, 10(2), 116-137.

Spohn, W. (1997). Spirituality and ethics: Exploring the connections. Theological Studies, 58 (1), 109-123.

Stankov, L. \& Lee, J. (2016). Nastiness, morality and religiosity in 33 nations. Personality and Individual Differences, 99, 56-66.

Stillman, T.F, Fincham, F.D., Vohs, K.D., Lambert, N.M. \& Phillips, C.A. (2012). The material and immaterial in conflict: Spirituality reduces conspicuous consumption. Journal of Economic Psychology, 33(1), 1-7.

Tajfel, H. (1972). Experiments in a vacuum. In the Context of Social Psychology (ed. by J. Isreal \& H. Tajfel). Academic Press, London.

Tajfel, H. \& Turner, J.C. (1979). An integrative theory of intergroup conflicts. In Differentiation Between Social Groups: Studies in the Social Psychology of

Page 210

(C) 2019 Journal of Asia Entrepreneurship and Sustainability Vol XV, Iss 1, June 2019 RossiSmith Academic Publications, Oxford/London UK, www.publicationsales.com 


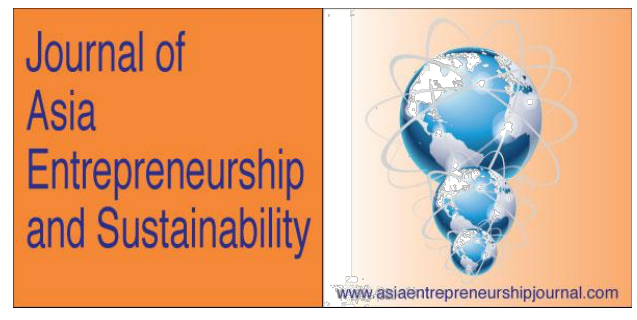

Intergroup Relations (ed. by W.G. Austion \& Worchel, S). 33-47. Brooks Cole, Monterey, CA.

Vazquez, P. (2018). Family business ethics: At crossroads of business ethics and family business. Journal of Business Ethics. 150, 691-709.

Vitell, S.J., Singh, J.J. \& Paolillo, J.G. (2007). Consumers' ethical beliefs: The roles of money, religiosity and attitude toward business. Journal of Business Ethics, 73(4), 369-379.

Weber, M (1958). The protestant ethics and the spirit of capitalism, NY, Charles Scribner's Son.

Wisker, Z.L \& Rosinaite, V. (2016). The effect of religiosity and personality on work ethics: A case of Muslim managers. Science Journal of Business Management, 4(1-1), 1-9.

Yang, Y. \& Huang, S. (2018). Religious beliefs in environmental behaviors in China. Religions, 9(72), 1-12.

Yazisi, O., McWillliams, D. \& Ercan, S. (2018). CSR comparison between family businesses and non-family business. Business \& Management Studies: An International Journal, 6(1), 256-280. 